\title{
Development of Acid Functional Groups and Lactones During the Thermal Degradation of Wood and Wood Components
}

Scientific Investigations Report 2007-5013 



\section{Development of Acid Functional Groups and Lactones During the Thermal Degradation of Wood and Wood Components}

By David W. Rutherford, Robert L. Wershaw, and James B. Reeves III

Scientific Investigations Report 2007-5013 


\title{
U.S. Department of the Interior DIRK KEMPTHORNE, Secretary
}

\author{
U.S. Geological Survey \\ Mark D. Myers, Director
}

\section{U.S. Geological Survey, Reston, Virginia 2008}

For product and ordering information:

World Wide Web: http://www.usgs.gov/pubprod

Telephone: 1-888-ASK-USGS

For more information on the USGS - the Federal source for science about the Earth, its natural and living resources, natural hazards, and the environment:

World Wide Web: http://www.usgs.gov

Telephone: 1-888-ASK-USGS

Any use of trade, product, or firm names is for descriptive purposes only and does not imply endorsement by the U.S. Government.

Although this report is in the public domain, permission must be secured from the individual copyright owners to reproduce any copyrighted material contained within this report.

Suggested citation:

Rutherford, D.W., Wershaw, R.L., and Reeves III, J.B., 2008, Development of acid functional groups and lactones during the thermal degradation of wood and wood components: U.S. Geological Survey Scientific Investigations Report 2007-5013, 43 p. 


\section{Contents}

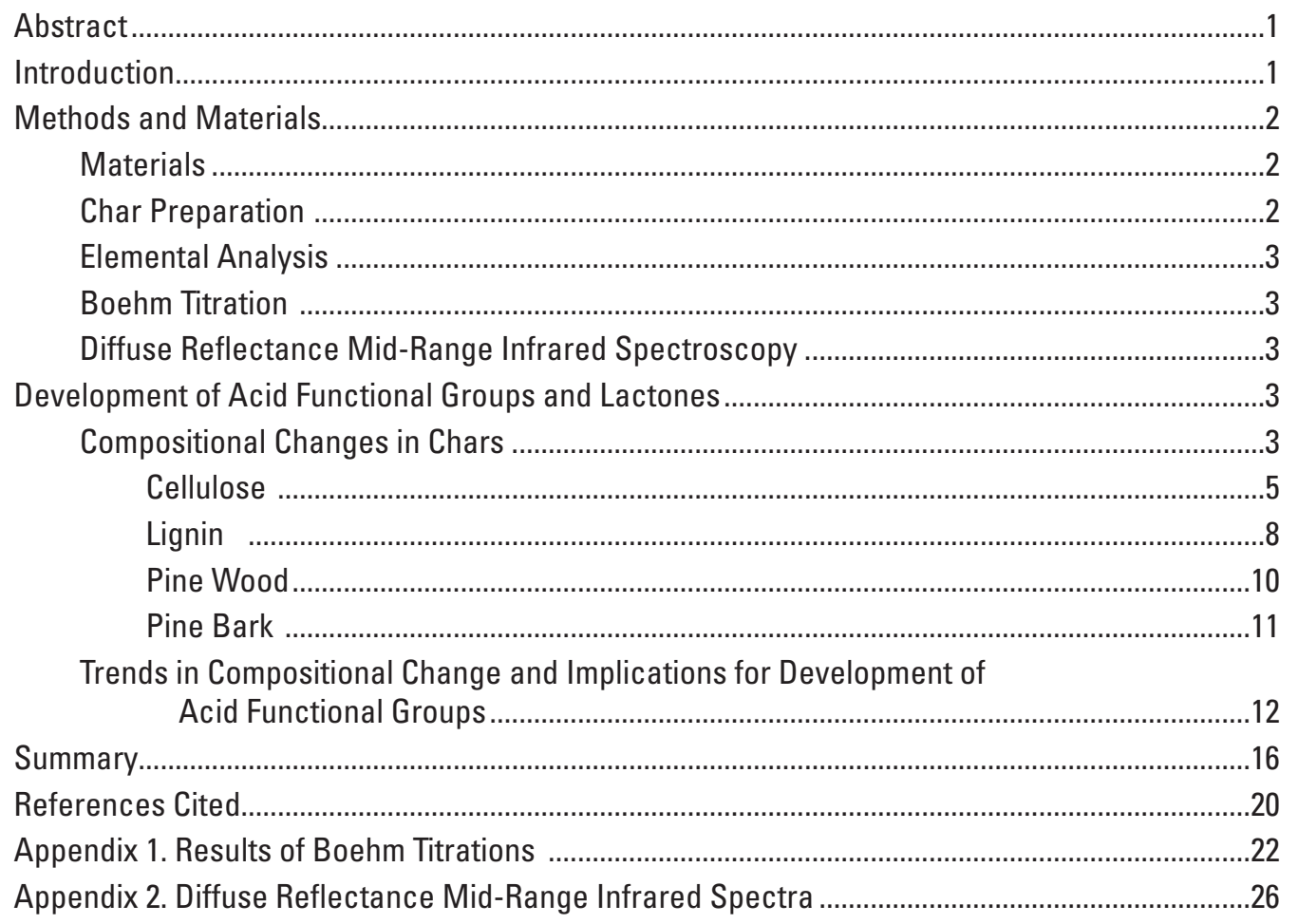




\section{Figures}

1. Illustrations of the calculations used in the Boehm titration method.

2. The mass loss of carbon and oxygen during the charring of cellulose at various charring times and temperatures.

3. The carbon-to-oxygen atomic ratio of cellulose chars at various charring times and temperatures.

4. The total acidity of cellulose chars at various charring times and temperatures...........14

5. The strong organic acid fraction of cellulose chars at various charring times and temperatures

6. The sum of the moderate acid and lactone fraction and weak organic acid fraction of cellulose chars at various charring times and temperatures.

7. The total acidity of cellulose, lignin, pine wood, and pine bark chars after 72 hours of charring at various temperatures

\section{Appendix Figures}

2-1. Diffuse reflectance mid-range infrared spectra of cellulose heated at $200^{\circ} \mathrm{C}$ for various times

2-2. Diffuse reflectance mid-range infrared spectra of cellulose heated at $250^{\circ} \mathrm{C}$ for various times.

2-3. Diffuse reflectance mid-range infrared spectra of cellulose heated at $300^{\circ} \mathrm{C}$ for various times.

2-4. Diffuse reflectance mid-range infrared spectra of cellulose heated at $350^{\circ} \mathrm{C}$ for various times.

2-5. Diffuse reflectance mid-range infrared spectra of cellulose heated at $400^{\circ} \mathrm{C}$ for various times.

2-6. Diffuse reflectance mid-range infrared spectra of lignin heated at $250^{\circ} \mathrm{C}$ for various times.

2-7. Diffuse reflectance mid-range infrared spectra of lignin heated at $300^{\circ} \mathrm{C}$ for various times.

2-8. Diffuse reflectance mid-range infrared spectra of lignin heated at $350^{\circ} \mathrm{C}$ for various times.

2-9. Diffuse reflectance mid-range infrared spectra of lignin heated at $400^{\circ} \mathrm{C}$ for various times.

2-10. Diffuse reflectance mid-range infrared spectra of lignin heated at $450^{\circ} \mathrm{C}$ and $500^{\circ} \mathrm{C}$ for various times

2-11. Diffuse reflectance mid-range infrared spectra of pine wood heated at $250^{\circ} \mathrm{C}$ for various times

2-12. Diffuse reflectance mid-range infrared spectra of pine wood heated at $300^{\circ} \mathrm{C}$ for various times.

2-13. Diffuse reflectance mid-range infrared spectra of pine wood heated at $350^{\circ} \mathrm{C}$ for various times. 
2-14. Diffuse reflectance mid-range infrared spectra of pine wood heated at $400^{\circ} \mathrm{C}$ and $500^{\circ} \mathrm{C}$ for various times

2-15. Diffuse reflectance mid-range infrared spectra of pine bark heated at

$250^{\circ} \mathrm{C}$ for various times

2-16. Diffuse reflectance mid-range infrared spectra of pine bark heated at $300^{\circ} \mathrm{C}$ for various times.

2-17. Diffuse reflectance mid-range infrared spectra of pine bark heated at $350^{\circ} \mathrm{C}$ for various times

2-18. Diffuse reflectance mid-range infrared spectra of pine bark heated at $400^{\circ} \mathrm{C}$ for various times

\section{Tables}

1. Carbon and oxygen content of cellulose and cellulose char............................................

2. Carbon and oxygen content of lignin and lignin char...................................................

3. Carbon and oxygen content of pine wood and pine wood char......................................6

4. Carbon and oxygen content of pine bark and pine bark char ............................................7

5. The results of the Boehm titration of cellulose and cellulose char shown as the milliequivalents of total acidity and its three fractions consisting of the strong organic acid fraction, the moderate organic acid and lactone fraction, and the weak organic acid fraction.

6. The results of the Boehm titration of lignin and lignin char shown as the milliequivalents of total acidity and its three fractions consisting of the strong organic acid fraction, the moderate organic acid and lactone fraction, and the weak organic acid fraction

7. The results of the Boehm titration of pine wood and pine wood char shown as the milliequivalents of total acidity and its three fractions consisting of the strong organic acid fraction, the moderate organic acid and lactone fraction, and the weak organic acid fraction

8. The results of the Boehm titration of pine bark and pine bark char shown as the milliequivalents of total acidity and its three fractions consisting of the strong organic acid fraction, the moderate organic acid and lactone fraction, and the weak organic acid fraction.

9. The pseudo-absorbance of selected absorbance bands for diffuse reflectance infrared spectroscopy of cellulose and cellulose char.

10. The pseudo-absorbance of selected absorbance bands for diffuse reflectance infrared spectroscopy of lignin and lignin char

11. The pseudo-absorbance of selected absorbance bands for diffuse reflectance infrared spectroscopy of pine wood and pine wood char.

12. The pseudo-absorbance of selected absorbance bands for diffuse reflectance infrared spectroscopy of pine bark and pine bark char 


\section{Appendix Tables}

1-1. Results of Boehm titrations for cellulose and cellulose chars ......................................23

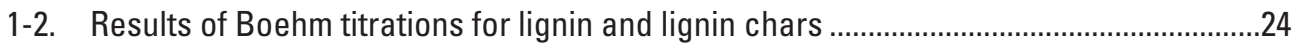

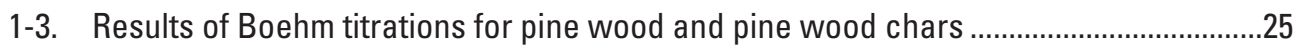

1-4. Results of Boehm titrations for pine bark and pine bark chars .......................................25 


\title{
Development of Acid Functional Groups and Lactones During the Thermal Degradation of Wood and Wood Components
}

\author{
By David W. Rutherford', Robert L. Wershaw', and James B. Reeves III'
}

\section{Abstract}

Black carbon (pyrogenic materials including chars) in soils has been recognized as a substantial portion of soil organic matter, and has been shown to play a vital role in nutrient cycling; however, little is known concerning the properties of this material. Previous studies have largely been concerned with the creation of high-surface-area materials for use as sorbents. These materials have been manufactured at high temperature and have often been activated. Chars occurring in the environment can be formed over a wide range of temperature. Because it is extremely difficult to isolate black carbon once it has been incorporated in soils, chars produced in the laboratory under controlled conditions can be used to investigate the range of properties possible for natural chars.

This report shows that charring conditions (temperature and time) have substantial impact on the acid functional group and lactone content of chars. Low temperatures $\left(250^{\circ} \mathrm{C}\right)$ and long charring times (greater than 72 hours) produce chars with the highest acid functional group and lactone content. The charring of cellulose appears to be responsible for the creation of the acid functional group and lactones.

The significance of this study is that low-temperature chars can have acid functional group contents comparable to humic materials (as high as 8.8 milliequivalents per gram). Acid functional group and lactone content decreases as charring temperature increases. The variation in formation conditions expected under natural fire conditions will result in a wide range of sorption properties for natural chars which are an important component of soil organic matter. By controlling the temperature and duration of charring, it is possible to tailor the sorption properties of chars, which may be used as soil amendments.

\section{Introduction}

The ability of soils to retain nutrients is a function of the exchange capacities of their mineral and organic components. The most active mineral components of soils with regard to ion-exchange reactions are the clay minerals and the hydrous metal oxides. Sposito and others (1999) have reviewed the mechanisms of metal-ion exchange reactions with clay minerals. Hydrous metal oxides undergo similar types of exchange reactions to clay minerals; however, the hydrous metal oxides do not have interlayer exchange positions like the clay minerals (Sahai, 2002; Sahai and Sverjensky, 1997). Hydrous metal oxide surfaces are generally coated with anionic natural organic matter (NOM) molecules that interact with dissolved metal ions in soil solutions (Wershaw and others, 1995; Zhou and others, 2001).

In addition to the anionic NOM species, pyrogenic carbon derived from the burning of biomass also is present in most soils (Glaser and others, 1998). Pyrogenic carbon (the so-called black carbon or charcoal fraction) is one of the least studied components of soil organic matter (SOM). Charcoal can markedly alter the physical and chemical properties of soils. Lehmann and others (2003) demonstrated that charcoal is crucial in maintaining fertility of the so-called 'terra preta' black soils of the Amazon Basin of Brazil. These soils occur in relatively small, isolated sites averaging about 20 hectares (ha) in area. The presence of charcoal in the terra preta soils differentiates them from the surrounding oxisols. This charcoal apparently was incorporated into the terra preta soils by native Indian farmers prior to the coming of Europeans to the New World and has persisted until the present. The presence of the charcoal greatly increases the capacity of these soils to bind nutrients such as nitrogen, phosphorus, calcium, and potassium; $\mathrm{pH}$ values and water-holding capacities also are higher. Charcoal is not only important in terra preta soils; it also constitutes a large fraction of the NOM in many of the

${ }^{1}$ U.S. Geological Survey, Denver, Colorado

${ }^{2}$ U.S. Department of Agriculture, Beltsville, Maryland 
most fertile agricultural soils in the world (Skjemstad and others, 2002). Liang and others (2006) have shown that black carbon increases the cation exchange capacity in soils.

Elucidation of the physical and chemical properties of charcoal in soils has been hampered by the difficulty of isolating natural charcoals from the soil components. Chun and others (2004a) evaluated the techniques that have been used to isolate charcoals from soils and concluded that the surface properties of the charcoal isolates are substantially altered by the isolation methods that are currently used. Therefore, Chun and others (2004b) studied the properties of the charcoal derived from pyrolysis of crop residues. They reasoned that these charcoals would be similar to the charcoals produced during field burning of vegetation and crop residues.

To better understand the range of properties that could be observed in natural char samples, several studies have used laboratory-produced chars that were produced under carefully controlled conditions. Rutherford and others (2004) produced charcoals from pine and poplar wood, pine bark, and purified cellulose and lignin, at temperatures from $250^{\circ} \mathrm{C}$ to $500^{\circ} \mathrm{C}$ and for times ranging from 1 hour to 168 hours. Changes in the chemical structures of the precursors were examined by Fourier transform infrared (FTIR) and ${ }^{13} \mathrm{C}$ nuclear magnetic resonance (NMR) spectrometry, and elemental composition. The porosities of the samples were measured by nitrogen adsorption. This work has provided a well-characterized suite of charcoals for ion-exchange studies. Brown and others (2006) produced chars that were characterized by heliumbased solid density, electrical resistance, elemental composition, and surface-area measurement.

The ion-exchange sites in charcoal consist mainly of oxygen-containing functional groups. The acid-base properties of activated carbons have been extensively studied (Contescu and others 1997; Lopez-Ramon and others, 1999; Salame and Bandosz, 2001); however, the exchange properties of soil charcoals should be substantially different from those of activated carbons because the conditions of formation are different.

Activated carbons are generally prepared at high temperatures in the presence of activating agents such as steam (Patrick, 1995). Soil charcoals, however, are generally produced at much lower temperatures by forest or grass fires.

To improve understanding of char development, the U.S. Geological Survey and the U. S. Department of Agriculture collaborated on a study to determine the conditions favorable to the formation of acid functional groups during charring. This will allow the estimation of the range of organic acid functional groups and lactones that could be expected in natural chars and also will provide insight into ways to produce chars with specific properties that could be tailored to specific uses.

This report describes development of acid functional groups and lactones during thermal degradation of wood and wood components. Data on the exchange properties of charcoals produced from cellulose, lignin, and pine wood and bark under controlled conditions of temperature and heating duration in the laboratory are provided. The Boehm titration method was used to measure the content of the acidic functional groups and lactones (total acidity) in the charcoals (Boehm and others, 1964). This method measures the amount of $\mathrm{NaOH}, \mathrm{NaHCO}_{3}$, and $\mathrm{Na}_{2} \mathrm{CO}_{3}$ neutralized by the char. The equivalents of $\mathrm{NaOH}$ neutralized by the char was used as the measure of total acid functional group and lactone content of the char. The difference in equivalents of base neutralized using the $\mathrm{NaOH}, \mathrm{NaHCO}_{3}$, and $\mathrm{Na}_{2} \mathrm{CO}_{3}$ treatments was used to subdivide the total acidity into three fractions consisting of the strong organic acid fraction, the moderate organic acid and lactone fraction, and the weak organic acid fraction. This is discussed in more detail in the next section.

Diffuse reflectance mid-range infrared (IR) spectroscopy and elemental composition will be compared to the titration results to elucidate processes taking place during charring which produce the acid functional groups and lactones.

\section{Methods and Materials}

\section{Materials}

Cellulose, purified from wood pulp, was obtained commercially as a microcrystalline powder (approximately 20 micrometer $(\mu \mathrm{m})$ particle size). The lignin was obtained commercially as a powder that had been extracted from mixed hardwoods by the Organosolv process (Allan, 1971, p. 540-541). The pine wood and bark samples were obtained in the Rocky Mountain foothills, north west of Denver, Colorado, from a cross-section of a ponderosa pine log (Pinus ponderosa). Pine bark material was collected from the same $\log$ and treated separately from the pine wood. The wood was shredded with a hand-held electric plane. The shavings were 1 millimeter (mm) or less in thickness, 2 to $4 \mathrm{~mm}$ in width and 1 centimeter $(\mathrm{cm})$ or less in length. Wood samples were airdried prior to use. The bark was air-dried and ground by using a hand mill.

\section{Char Preparation}

Char was prepared by weighing the shredded or powdered sample into 250-milliliter $(\mathrm{mL})$ porcelain crucibles. The crucibles were heated without tops, with between 10 and 20 grams (g) of material per crucible. The crucibles were placed in a muffle furnace preheated to the desired temperature, with nitrogen flow sufficient to produce three air changes per minute within the furnace. The nitrogen used was ultra high purity (UHP) grade with less than 1 part per million (ppm) oxygen. After heating, crucibles were placed in a nitrogen-filled desiccator to cool to room temperature. The char was then pulverized with a mortar and pestle. The percentage yield was determined by weighing samples before and after heating and has been previously reported (Rutherford and others, 2004). 


\section{Elemental Analysis}

Carbon and hydrogen were determined by combustion in oxygen at $1000^{\circ} \mathrm{C}$; the combustion products were passed through catalysts to ensure complete oxidation. Water was trapped, and carbon dioxide $\left(\mathrm{CO}_{2}\right)$ was measured with a $\mathrm{CO}_{2}$ coulometer. Moisture was determined by loss on drying at $105^{\circ} \mathrm{C}$ overnight. Ash content was determined by combustion in air at $750^{\circ} \mathrm{C}$. The results for carbon, hydrogen, and ash have been previously reported (Rutherford and others. 2004). Cellulose and lignin did not contain any ash. The moisture content for all samples and the ash content for wood and bark samples were used to adjust the carbon and hydrogen percentage to a dry and ash-free basis. Oxygen was then determined as the difference between the sum of the carbon and hydrogen percentage and 100 percent. The results for carbon and oxygen are summarized in tables 1 through 4 .

\section{Boehm Titration}

Approximately 0.25 gram (g) of char was weighed into each of three $60-\mathrm{mL}$ polypropylene bottles. One bottle each was filled with $50 \mathrm{~mL}$ of 0.05 molar $\mathrm{NaOH}, \mathrm{NaHCO}_{3}$, or $\mathrm{Na}_{2} \mathrm{CO}_{3}$. Each solution was made with a constant ionic strength background of 0.1 molar $\mathrm{NaNO}_{3}$. A control without char for each solution also was prepared. Samples and controls were equilibrated on a tube rotator for approximately 16 hours. The solutions with char were filtered through 0.1-micrometer glass fiber filters. An aliquot of each solution was titrated with 0.05 molar $\mathrm{HCl}$. The amount of base neutralized by the char was determined by the difference between the solution containing char and the control solution. Each char sample was analyzed in duplicate.

The total acidity is considered to be the amount of $\mathrm{NaOH}$ neutralized and will consist of any organic acids with an acid dissociation constant ( $\mathrm{pKa}$ ) less than 12, and those acids formed when lactones hydrolyze. The amount of $\mathrm{NaHCO}_{3}$ neutralized is considered to be due to the strongest of the organic acids and is assumed to be primarily carboxylic acids, referred to as strong acid fraction. The amount of $\mathrm{Na}_{2} \mathrm{CO}_{3}$ neutralized is considered to be due to the strong organic acid fraction, and the moderate strength organic acids (low pKa phenols) and lactones fraction. When lactones hydrolyze into carboxylic acids and phenols, the carboxylic acids and some or all of the phenols are expected to be neutralized by the $\mathrm{Na}_{2} \mathrm{CO}_{3}$. The difference between the milliequivalents (meq) of $\mathrm{NaHCO}_{3}$ and $\mathrm{Na}_{2} \mathrm{CO}_{3}$ neutralized will be referred to as moderate organic acid and lactone fraction with the understanding that this category can include the neutralization of the carboxylic acids and phenol components of lactones after hydrolysis. The difference between the milliequivalents of $\mathrm{NaOH}$ and $\mathrm{Na}_{2} \mathrm{CO}_{3}$ neutralized is composed of the weakest organic acids, assumed to be the high $\mathrm{pKa}$ phenols, and is referred to as weak acid fraction. Some of the phenols could come from the hydroysis of lactones. These calculations are illustrated in figure 1.

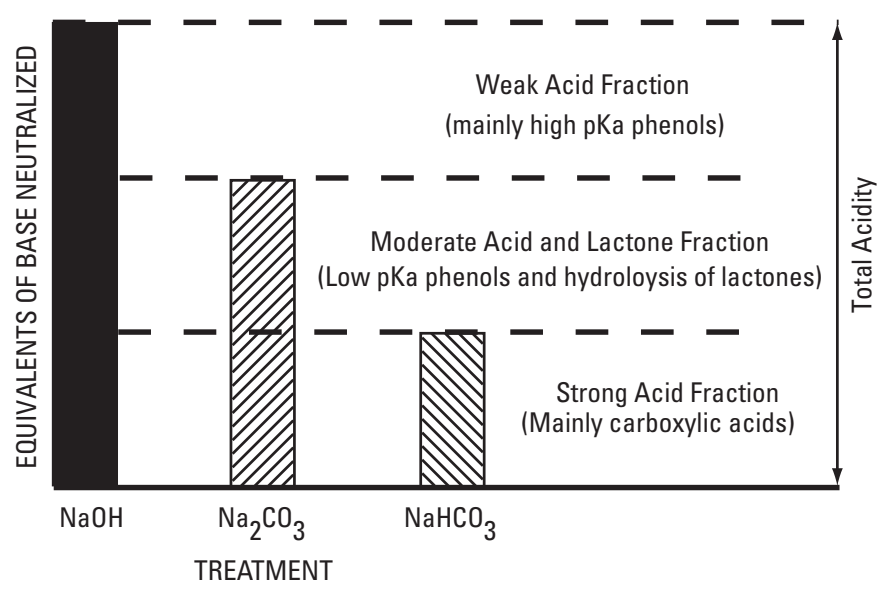

Figure 1. Illustrations of the calculations used in the Boehm titration method.

\section{Diffuse Reflectance Mid-Range Infrared Spectroscopy}

The diffuse reflectance of all samples was scanned in the mid-range infrared from 4000 to $400 \mathrm{~cm}^{-1}$ at $4 \mathrm{~cm}^{-1}$ resolution on a Digilab (Varian, Inc., Palo Alto, Calif.) FTS 7000 Fourier transform spectrometer equipped with a DTGS (deuterated triglycine sulfate) detector and a $\mathrm{KBr}$ beam splitter. Each spectrum consists of 64 co-added scans. Spectra were obtained in diffuse reflectance mode by using a Pike (Pike Technologies, Madison, Wis.) AutoDiff auto-sampler with $\mathrm{KBr}$ as the background sample and data computed as pseudo-absorbance, $\log _{10} 1 / \mathrm{R}$, where $\mathrm{R}$ is the relative reflectance at a given wave length. The term pseudo-absorbance is used to differentiate reflectance spectra (pseudo-absorbance) from transmittance spectra (absorbance). The samples were ground and analyzed neat (not diluted with $\mathrm{KBr}$ ). The use of neat samples allows for the relative comparison between reflectance spectra of pseudoabsorbance for specific wave lengths.

\section{Development of Acid Functional Groups and Lactones}

\section{Compositional Changes in Chars}

Elemental analyses (carbon and oxygen) are shown in tables 1 through 4 , as percentage of the char on dry-weight and ash-free basis. The percentage mass lost during charring is shown, as well as the calculated percentage of carbon and oxygen lost.

The results of the neutralization of the $\mathrm{NaOH}, \mathrm{NaHCO}_{3}$, and $\mathrm{Na}_{2} \mathrm{CO}_{3}$ solutions are shown in Appendix 1, along with the standard error of the mean. Each titration was performed at 
Table 1. Carbon and oxygen content of cellulose and cellulose char.

[The mass of carbon and oxygen lost is shown as a percentage of the starting mass of carbon or oxygen; ${ }^{\circ} \mathrm{C}$, degrees Celsius]

\begin{tabular}{|c|c|c|c|c|c|c|}
\hline $\begin{array}{l}\text { Charring } \\
\text { conditions }\end{array}$ & $\begin{array}{l}\text { Percent' carbon } \\
\text { in char }\end{array}$ & $\begin{array}{l}\text { Percent' oxygen } \\
\text { in char }\end{array}$ & $\begin{array}{l}\text { Carbon to Oxygen } \\
\text { atomic ratio }\end{array}$ & $\begin{array}{l}\text { Percent mass } \\
\text { lost }\end{array}$ & $\begin{array}{c}\text { Percent carbon } \\
\text { lost }\end{array}$ & $\begin{array}{c}\text { Percent oxygen } \\
\text { lost }\end{array}$ \\
\hline $\begin{array}{l}\text { Unaltered } \\
\text { Cellulose }\end{array}$ & 44.4 & 49.4 & 1.2 & 0 & 0 & 0 \\
\hline \multicolumn{7}{|c|}{ Cellulose Char } \\
\hline \multicolumn{7}{|l|}{$200^{\circ} \mathrm{C}$} \\
\hline 72 hours & 46.2 & 47.6 & 1.3 & 7.9 & 4.1 & 11.3 \\
\hline 168 hours & 50.2 & 44.4 & 1.5 & 22.2 & 12.0 & 30.0 \\
\hline \multicolumn{7}{|l|}{$250^{\circ} \mathrm{C}$} \\
\hline 1 hour & 44.1 & 49.6 & 1.2 & 6.4 & 7.0 & 6.0 \\
\hline 8 hours & 65.1 & 31.2 & 2.8 & 55.9 & 35.3 & 72.2 \\
\hline 24 hours & 63.7 & 33.9 & 2.5 & 64.5 & 49.0 & 75.6 \\
\hline 48 hours & 64.5 & 33.0 & 2.6 & 65.3 & 49.6 & 76.8 \\
\hline 72 hours & 63.3 & 34.5 & 2.4 & 68.6 & 55.2 & 78.1 \\
\hline 168 hours & 65.1 & 33.2 & 2.6 & 71.1 & 57.7 & 80.6 \\
\hline \multicolumn{7}{|l|}{$300^{\circ} \mathrm{C}$} \\
\hline 1 hour & 73.0 & 23.0 & 4.2 & 66.7 & 45.2 & 84.5 \\
\hline 8 hours & 71.0 & 26.0 & 3.6 & 69.3 & 50.9 & 83.8 \\
\hline 24 hours & 69.3 & 29.3 & 3.2 & 72.8 & 57.6 & 83.9 \\
\hline 48 hours & 65.4 & 32.8 & 2.7 & 76.1 & 64.8 & 84.2 \\
\hline 72 hours & 64.4 & 33.7 & 2.5 & 77.8 & 67.8 & 84.9 \\
\hline \multicolumn{7}{|l|}{$350^{\circ} \mathrm{C}$} \\
\hline 1 hour & 75.4 & 20.9 & 4.8 & 72.2 & 52.8 & 88.3 \\
\hline 8 hours & 74.3 & 23.1 & 4.3 & 76.5 & 60.7 & 89.0 \\
\hline 24 hours & 69.2 & 28.9 & 3.2 & 81.4 & 71.0 & 89.1 \\
\hline 48 hours & 66.2 & 32.0 & 2.8 & 84.8 & 77.3 & 90.2 \\
\hline 72 hours & 65.3 & 32.9 & 2.6 & 88.7 & 83.4 & 92.5 \\
\hline \multicolumn{7}{|l|}{$400^{\circ} \mathrm{C}$} \\
\hline 1 hour & 78.5 & 18.1 & 5.8 & 77.7 & 60.6 & 91.8 \\
\hline 8 hours & 77.6 & 20.2 & 5.1 & 81.0 & 66.8 & 92.2 \\
\hline 24 hours & 76.2 & 22.8 & 4.5 & 87.2 & 79.2 & 93.2 \\
\hline 48 hours & 71.5 & 27.4 & 3.5 & 95.0 & 91.9 & 97.2 \\
\hline 72 hours & 71.5 & 27.2 & 3.5 & 97.6 & 96.1 & 98.7 \\
\hline
\end{tabular}

${ }^{1}$ Dry weight and ash-free basis

least twice for all samples and additionally as needed so that the standard error of the mean was less than 10 percent. The total acidity and the three fractions calculated according to the Boehm method are shown in tables 5 through 8 .

Previous work (Rutherford and others, 2004) reported infrared transmittance spectra for wood and wood component chars. In this study, IR-reflectance spectrometry has been used to further quantify the results that were observed for the IR-transmittance spectrometry. The infrared reflectance spectra were obtained from neat samples and have been used on a semi-quantitative basis to examine trends with time and temperature of char formation. These spectra are provided in
Appendix 2. Four regions have been tabulated because they show the greatest response with charring. The pseudoabsorbance for the major bands in the regions of 3500 to 3300,3000 to 2800,1750 to 1700 , and 1650 to $1610 \mathrm{~cm}^{-1}$ are provided in tables 9 through 12 . The broad band between 3500 and $3300 \mathrm{~cm}^{-1}$ is characteristic of the $\mathrm{OH}$ stretching mode (Colthup and others, 1990). Decreases in this region are associated with the loss of oxygen during charring. The bands between 3000 and $2800 \mathrm{~cm}^{-1}$ are characteristic of the stretching modes of $\mathrm{CH}_{3}, \mathrm{CH}_{2}$, and $\mathrm{CH}$ groups. Decreases in this region are associated with the loss of aliphatic carbon during charring. The sharp bands between about 1750 and $1700 \mathrm{~cm}^{-1}$ 
Table 2. Carbon and oxygen content of lignin and lignin char.

[The mass of carbon and oxygen lost is shown as a percentage of the starting mass of carbon or oxygen; ${ }^{\circ} \mathrm{C}$, degrees Celsius]

\begin{tabular}{|c|c|c|c|c|c|c|}
\hline $\begin{array}{l}\text { Charring } \\
\text { conditions }\end{array}$ & $\begin{array}{l}\text { Percent }{ }^{1} \text { carbon } \\
\text { inchar }\end{array}$ & $\begin{array}{l}\text { Percent }{ }^{1} \text { oxygen } \\
\text { in char }\end{array}$ & $\begin{array}{l}\text { Carbon to Oxygen } \\
\text { atomic ratio }\end{array}$ & $\begin{array}{c}\text { Percent mass } \\
\text { lost }\end{array}$ & $\begin{array}{l}\text { Percent carbon } \\
\text { lost }\end{array}$ & $\begin{array}{c}\text { Percent oxygen } \\
\text { lost }\end{array}$ \\
\hline $\begin{array}{l}\text { Unaltered } \\
\text { Lignin }\end{array}$ & 67.5 & 26.6 & 3.4 & 0 & 0 & 0 \\
\hline \multicolumn{7}{|c|}{ Lignin Char } \\
\hline \multicolumn{7}{|l|}{$250^{\circ} \mathrm{C}$} \\
\hline 24 hours & 71.6 & 23.2 & 4.1 & 15.3 & 10.3 & 26.4 \\
\hline 72 hours & 70.3 & 24.7 & 3.8 & 19.4 & 16.2 & 25.3 \\
\hline 168 hours & 72.2 & 23.3 & 4.1 & 23.3 & 18.0 & 33.1 \\
\hline \multicolumn{7}{|l|}{$300^{\circ} \mathrm{C}$} \\
\hline 1 hour & 71.2 & 23.6 & 4.0 & 23.2 & 19.1 & 32.0 \\
\hline 8 hours & 72.2 & 23.1 & 4.2 & 30.0 & 25.2 & 39.2 \\
\hline 24 hours & 73.8 & 22.2 & 4.4 & 32.2 & 26.0 & 43.4 \\
\hline 48 hours & 71.2 & 25.1 & 3.8 & 36.3 & 33.0 & 40.1 \\
\hline 72 hours & 69.9 & 27.5 & 3.4 & 40.7 & 38.7 & 39.0 \\
\hline \multicolumn{7}{|l|}{$350^{\circ} \mathrm{C}$} \\
\hline 1 hour & 74.3 & 21.6 & 4.6 & 35.7 & 29.4 & 47.9 \\
\hline 8 hours & 73.5 & 23.5 & 4.2 & 44.7 & 39.9 & 51.2 \\
\hline 24 hours & 69.3 & 28.9 & 3.2 & 47.2 & 45.8 & 42.7 \\
\hline 48 hours & 67.6 & 30.8 & 2.9 & 67.2 & 67.2 & 62.1 \\
\hline 72 hours & 66.3 & 32.1 & 2.8 & 66.1 & 66.8 & 59.3 \\
\hline \multicolumn{7}{|l|}{$400^{\circ} \mathrm{C}$} \\
\hline 1 hour & 76.7 & 19.8 & 5.2 & 48.2 & 41.2 & 61.4 \\
\hline 8 hours & 73.9 & 23.8 & 4.1 & 61.8 & 58.3 & 65.9 \\
\hline 24 hours & 73.2 & 25.8 & 3.8 & 70.6 & 68.2 & 71.6 \\
\hline 48 hours & 72.2 & 26.5 & 3.6 & 88.2 & 87.4 & 88.3 \\
\hline 72 hours & 71.5 & 27.4 & 3.5 & 96.8 & 96.7 & 96.8 \\
\hline \multicolumn{7}{|l|}{$450^{\circ} \mathrm{C}$} \\
\hline 24 hours & 79.3 & 19.6 & 5.5 & 86.2 & 83.8 & 90.1 \\
\hline
\end{tabular}

${ }^{1}$ Dry weight and ash-free basis

most likely represent carbonyl-stretching bands of lactones and carboxylic acids. Increases in this region are associated with the creation of lactones and carboxylic acids during charring. The band between 1650 and $1610 \mathrm{~cm}^{-1}$ represents skeletal vibrations of fused-ring aromatic structures and conjugated ketones. The growth of this band during charring reflects the increase in aromaticity and the possible presence of hydrogen bonded quinones.

\section{Cellulose}

Cellulose was the only material charred at $200^{\circ} \mathrm{C}$. After 72 and 168 hours of heating, 7.9 and 22.2 percent of the original mass had been lost, which shows that little thermal degradation occurs at this temperature. The percentage oxygen in the char had decreased by 1.8 and 5 percent, respectively.
The carbon-to-oxygen atomic ratio did not change appreciably with charring at this temperature (table1).

Unaltered cellulose has less than 0.1 milliequivalents per gram (meq $/ \mathrm{g}$ ) of total acidity. When heated at $200^{\circ} \mathrm{C}$ for 72 and 168 hours, the total acidity of cellulose was 0.66 and $1.96 \mathrm{meq} / \mathrm{g}$, respectively. The increase in total acidity after 72 hours was due to increases of $0.15,0.36$, and $0.15 \mathrm{meq} / \mathrm{g}$ in the strong acid fraction, moderate acid and lactone fraction and weak acid fraction, respectively (table 5). The increase in total acidity after 168 hours was due to increases of $0.41,0.61$, and $0.94 \mathrm{meq} / \mathrm{g}$ in the strong acid fraction, moderate acid and lactone fraction, and weak acid fraction, respectively (table 5).

The infrared reflectance spectra for cellulose charred at $200^{\circ} \mathrm{C}$ are shown in Appendix 2, figure 2-1. The bands at 3449 and $2901 \mathrm{~cm}^{-1}$ showed no substantial change after heating for 72 and 168 hours at $200^{\circ} \mathrm{C}$. The band at $1722 \mathrm{~cm}^{-1}$ increased 
Table 3. Carbon and oxygen content of pine wood and pine wood char.

[The mass of carbon and oxygen lost is shown as a percentage of the starting mass of carbon or oxygen; ${ }^{\circ} \mathrm{C}$, degrees Celsius]

\begin{tabular}{|c|c|c|c|c|c|c|}
\hline $\begin{array}{l}\text { Charring } \\
\text { conditions }\end{array}$ & $\begin{array}{l}\text { Percent }{ }^{1} \text { carbon } \\
\text { in char }\end{array}$ & $\begin{array}{l}\text { Percent }{ }^{1} \text { oxygen } \\
\text { in char }\end{array}$ & $\begin{array}{l}\text { Carbon to Oxygen } \\
\text { atomic ratio }\end{array}$ & $\begin{array}{c}\text { Percent mass } \\
\text { lost }\end{array}$ & $\begin{array}{c}\text { Percent carbon } \\
\text { lost }\end{array}$ & $\begin{array}{c}\text { Percent oxygen } \\
\text { lost }\end{array}$ \\
\hline $\begin{array}{l}\text { Unaltered } \\
\text { Pine Wood }\end{array}$ & 51.2 & 42.5 & 1.6 & 0 & 0 & 0 \\
\hline \multicolumn{7}{|c|}{ Pine Wood Char } \\
\hline \multicolumn{7}{|l|}{$250^{\circ} \mathrm{C}$} \\
\hline 1 hour & 53.7 & 40.4 & 1.8 & 20.8 & 16.8 & 24.6 \\
\hline 8 hours & 63.0 & 32.5 & 2.6 & 44.2 & 31.4 & 57.3 \\
\hline 24 hours & 65.4 & 31.7 & 2.8 & 56.7 & 44.8 & 67.8 \\
\hline 48 hours & 65.5 & 32.0 & 2.7 & 63.8 & 53.8 & 72.8 \\
\hline 72 hours & 65.9 & 32.0 & 2.7 & 63.9 & 53.6 & 72.9 \\
\hline 168 hours & 62.8 & 35.0 & 2.4 & 69.8 & 63.1 & 75.3 \\
\hline \multicolumn{7}{|l|}{$300^{\circ} \mathrm{C}$} \\
\hline 1 hour & 69.1 & 26.6 & 3.5 & 57.6 & 42.8 & 73.5 \\
\hline 8 hours & 71.2 & 25.7 & 3.7 & 67.1 & 54.4 & 80.2 \\
\hline 24 hours & 67.1 & 30.6 & 2.9 & 74.9 & 67.4 & 82.1 \\
\hline 48 hours & 67.3 & 30.9 & 2.9 & 80.1 & 74.1 & 85.7 \\
\hline 72 hours & 65.9 & 32.0 & 2.7 & 82.8 & 78.1 & 87.2 \\
\hline \multicolumn{7}{|l|}{$350^{\circ} \mathrm{C}$} \\
\hline 1 hour & 76.2 & 20.5 & 4.9 & 73.2 & 60.3 & 87.1 \\
\hline 8 hours & 69.8 & 28.0 & 3.3 & 78.9 & 71.7 & 86.3 \\
\hline 24 hours & 68.9 & 28.5 & 3.2 & 94.9 & 93.8 & 96.9 \\
\hline \multicolumn{7}{|l|}{$400^{\circ} \mathrm{C}$} \\
\hline 1 hour & 77.4 & 20.0 & 5.2 & 77.5 & 66.2 & 89.5 \\
\hline 8 hours & 79.4 & 18.1 & 5.8 & 86.1 & 78.7 & 94.2 \\
\hline
\end{tabular}

${ }^{1}$ Dry weight and ash-free basis

by 0.50 and 0.93 pseudo-absorbance units (PAU), respectively. The band at $1626 \mathrm{~cm}^{-1}$ increased by 0.15 and $0.45 \mathrm{PAU}$, respectively. In the region between 1400 and $900 \mathrm{~cm}^{-1}$, the individual cellulose bands remained distinct and showed no substantial change. The change in total acidity was reflected by changes in the $1722 \mathrm{~cm}^{-1}$ band, which is indicative of carbonyl formation. The change in aromaticity of the sample was reflected by changes in the $1626 \mathrm{~cm}^{-1}$ band (table 9).

After heating at $250^{\circ} \mathrm{C}$ for 168 hours, cellulose lost 71.1 percent of the original mass, which shows that considerable degradation has occurred. While little mass is lost in the first hour (6.4 percent), 55.9 percent was lost in the first 8 hours. The percentage oxygen in the char remains constant for the first hour, decreased from 49.4 percent for unaltered cellulose to 31.2 percent after 8 hours, and then increased slightly to 33.2 percent after 168 hours. The carbon-to-oxygen ratio increases from 1.2 percent for unaltered cellulose to 2.8 at 8 hours and remains constant for longer charring times (table 1). The losses in oxygen and carbon mass are shown in figure 2. The changes in carbon-to-oxygen ratio are shown in figure 3.

For cellulose char produced at $250^{\circ} \mathrm{C}$, total acidity increased to $3.93 \mathrm{meq} / \mathrm{g}$ at 8 hours and to $8.83 \mathrm{meq} / \mathrm{g}$ at 168 hours. After 168 hours, the total acidity was composed of $3.84,2.54$, and $2.46 \mathrm{meq} / \mathrm{g}$ in the strong acid fraction, moderate acid and lactone fraction and weak acid fraction, respectively. The percentages of strong acid fraction, moderate acid and lactone fraction and weak acid fraction after 8 hours were 21, 29, and 50 percent. After 168 hours, the percentages were 43,29 , and 28 percent, respectively. Although total acidity increased with charring time, strong acid fraction increased the most, and continued to increase with long duration of charring. The weak acid fraction appears to have maximized in the first 8 hours of charring (table 5). The increases in total acidity by time and temperature are shown in figure 4 . The changes in strong organic acid fraction by time and temperature are shown in figure 5 . The combined changes in the moderate acid and lactone fraction and weak acid fraction 
Table 4. Carbon and oxygen content of pine bark and pine bark char.

[The mass of carbon and oxygen lost is shown as a percentage of the starting mass of carbon or oxygen; ${ }^{\circ} \mathrm{C}$, degrees Celsius]

\begin{tabular}{|c|c|c|c|c|c|c|}
\hline $\begin{array}{l}\text { Charring } \\
\text { conditions }\end{array}$ & $\begin{array}{l}\text { Percent }{ }^{1} \text { carbon } \\
\text { in char }\end{array}$ & $\begin{array}{l}\text { Percent }{ }^{1} \text { oxygen } \\
\text { in char }\end{array}$ & $\begin{array}{l}\text { Carbon to Oxygen } \\
\text { atomic ratio }\end{array}$ & $\begin{array}{l}\text { Percent mass } \\
\text { lost }\end{array}$ & $\begin{array}{l}\text { Percent carbon } \\
\text { lost }\end{array}$ & $\begin{array}{l}\text { Percent oxygen } \\
\text { lost }\end{array}$ \\
\hline $\begin{array}{l}\text { Unaltered } \\
\text { Pine Bark }\end{array}$ & 51.3 & 42.7 & 1.6 & 0 & 0 & 0 \\
\hline \multicolumn{7}{|c|}{ Pine Bark Char } \\
\hline \multicolumn{7}{|l|}{$250^{\circ} \mathrm{C}$} \\
\hline 1 hour & 57.4 & 37.3 & 2.0 & 26.7 & 18.6 & 36.3 \\
\hline 8 hours & 62.4 & 33.7 & 2.5 & 39.8 & 28.1 & 53.4 \\
\hline 24 hours & 62.6 & 34.2 & 2.4 & 48.1 & 38.2 & 59.4 \\
\hline 72 hours & 60.1 & 37.5 & 2.1 & 57.3 & 52.2 & 64.1 \\
\hline 168 hours & 59.2 & 38.5 & 2.1 & 65.7 & 62.6 & 70.8 \\
\hline \multicolumn{7}{|l|}{$300^{\circ} \mathrm{C}$} \\
\hline 1 hour & 65.6 & 30.1 & 2.9 & 46.3 & 32.8 & 62.8 \\
\hline 8 hours & 64.6 & 32.1 & 2.7 & 52.5 & 42.1 & 65.4 \\
\hline 24 hours & 63.0 & 34.1 & 2.5 & 64.5 & 58.4 & 72.9 \\
\hline 48 hours & 60.2 & 37.4 & 2.1 & 75.7 & 73.6 & 80.2 \\
\hline 72 hours & 57.2 & 40.3 & 1.9 & 81.9 & 82.6 & 85.2 \\
\hline \multicolumn{7}{|l|}{$350^{\circ} \mathrm{C}$} \\
\hline 1 hour & 68.3 & 28.0 & 3.3 & 55.5 & 42.7 & 71.8 \\
\hline 8 hours & 68.5 & 28.2 & 3.2 & 66.7 & 58.4 & 79.4 \\
\hline 24 hours & 65.0 & 32.1 & 2.7 & 80.5 & 78.3 & 87.1 \\
\hline 48 hours & 52.0 & 46.0 & 1.5 & 90.9 & 93.5 & 93.1 \\
\hline \multicolumn{7}{|l|}{$400^{\circ} \mathrm{C}$} \\
\hline 8 hours & 80.8 & 15.8 & 6.8 & 71.3 & 61.0 & 90.9 \\
\hline
\end{tabular}

${ }^{1}$ Dry weight and ash-free basis

content of cellulose chars by time and temperature are shown in figure 6 .

The infrared reflectance spectra for cellulose charred at $250^{\circ} \mathrm{C}$ are shown in Appendix 2, figure 2-2. The maximum absorbance between 3500 and $3300 \mathrm{~cm}^{-1}$ shows little change in the first hour but decreases by 0.76 PAU by 8 hours, which is consistent with the loss of oxygen from the char. By 24 hours, the absorbance band has broadened and is showing a shoulder at $3070 \mathrm{~cm}^{-1}$, which could indicate the C-H stretching of aromatic compounds. The maximum absorbance between 3000 and $2800 \mathrm{~cm}^{-1}$ shows no substantial change for one hour of charring. There was a reduction of 0.54 PAU after 8 hours and after 24 hours there was no absorbance band remaining. This is consistent with the loss of aliphatic carbon as determined by ${ }^{13} \mathrm{C}$ NMR in previous work (Rutherford and others, 2004). By 8 hours, the maximum absorbance between 1750 and $1700 \mathrm{~cm}^{-1}$ has increased by 1.33 PAU and remains constant for longer charring times. There is a consistent shift in band location from 1728 to $1755 \mathrm{~cm}^{-1}$ with prolonged charring. The maximum absorbance between 1650 and $1610 \mathrm{~cm}^{-1}$ increases by $0.91 \mathrm{PAU}$ in the first 8 hours and then remains relatively constant for longer charring times (table 9). In the region between 1400 and $900 \mathrm{~cm}^{-1}$, the individual cellulose bands coalesce into one broad band by 8 hours.

For cellulose charred at $300^{\circ} \mathrm{C}$ for 8 hours, 69 percent total mass, 51 percent of the carbon mass, and 84 percent of the oxygen mass is lost. After 72 hours of charring at $300^{\circ} \mathrm{C}$, 78 percent total mass, 68 percent of the carbon mass, and 85 percent of the oxygen mass is lost. The carbon-to-oxygen ratio increased to 3.6 after 8 hours and decreases to 2.5 after 72 hours. For cellulose charred at $350^{\circ} \mathrm{C}$ for 8 hours, 77 percent total mass, 61 percent of the carbon mass, and 89 percent of the oxygen mass was lost. After 72 hours of charring at $350^{\circ} \mathrm{C}, 89$ percent total mass, 83 percent of the carbon mass, and 93 percent of the oxygen mass has been lost. The carbon-to-oxygen ratio has increased to 4.3 after 8 hours and then decreases to 2.6 after 72 hours. For cellulose charred at $400^{\circ} \mathrm{C}$ for 8 hours, 81 percent of the total mass, 81 percent of the carbon mass, and 93 percent of the oxygen mass was lost. After 72 hours of charring at $400^{\circ} \mathrm{C}, 98$ percent of the total mass, 96 percent of the carbon mass, and 99 percent of the oxygen mass has been lost. The carbon-to-oxygen ratio has 
increased to 5.1 after 8 hours and then decreased to 3.5 after 72 hours (table 1).

For cellulose chars produced at $300^{\circ} \mathrm{C}, 350^{\circ} \mathrm{C}$, and $400^{\circ} \mathrm{C}$, for 8 hours charring time, total acidity was $4.04,3.04$ and $2.35 \mathrm{meq} / \mathrm{g}$, respectively. For cellulose chars produced at $300^{\circ} \mathrm{C}, 350^{\circ} \mathrm{C}$, and $400^{\circ} \mathrm{C}$, for 72 hours charring time, total acidities were $7.38,5.62$ and $4.04 \mathrm{meq} / \mathrm{g}$ respectively. When charred for 8 hours at $300^{\circ} \mathrm{C}, 350^{\circ} \mathrm{C}$ and $400^{\circ} \mathrm{C}$, the percentages of the strong acid fraction were 24, 29, and 16 percent respectively. When charred for 72 hours at $300^{\circ} \mathrm{C}, 350^{\circ} \mathrm{C}$ and $400^{\circ} \mathrm{C}$, the percentage of the strong acid fraction was 34,30 , and 30 percent respectively. The strong acid fraction and moderate acid and lactone fraction increased with longer duration of charring. All three fractions showed decreases in quantity with increasing temperature (table 5).

The infrared reflectance spectra for cellulose charred at 300, 350, and $400^{\circ} \mathrm{C}$ are shown in Appendix 2, figures 2-3, -4, and -5 . The maximum absorbances for bands between 3500 and $3300 \mathrm{~cm}^{-1}$ for chars produced at 300,350 , and $400^{\circ} \mathrm{C}$ for 8 hours, are $0.56,0.42$, and $0.24 \mathrm{PAU}$, respectively. After charring for 72 hours, the maximum absorbances are 0.76 , 0.59 , and 0.28 PAU, respectively. The decrease in absorbance at higher charring temperature is consistent with the lower percentage of oxygen at higher charring temperature. The absorbance band between 3000 and $2800 \mathrm{~cm}^{-1}$ disappears for chars heated for greater than 8 hours at $300^{\circ} \mathrm{C}$, and 1 hour at 350 and $400^{\circ} \mathrm{C}$. For chars produced at 300,350 , and $400^{\circ} \mathrm{C}$ for 8 hours, the maximum absorbances between 1750 and $1700 \mathrm{~cm}^{-1}$ are $1.23,1.07$, and $0.88 \mathrm{PAU}$, respectively. After 72 hours, the maximum absorbances are 1.48, 1.37, and 1.14 PAU, respectively. There is a shift in absorbance band location from about 1710 to $1760 \mathrm{~cm}^{-1}$ with increased charring time at all temperatures. The maximum absorbance between 1650 and $1610 \mathrm{~cm}^{-1}$ for chars produced at 300,350 , and $400^{\circ} \mathrm{C}$ for 8 hours, are 1.17, 1.14, and 1.23 PAU, respectively. After charring for 72 hours, the maximum absorbances are 1.34, 1.31, and 1.19 PAU, respectively (table 9).

For cellulose chars produced at temperatures above $250^{\circ} \mathrm{C}$, the change in maximum absorbance between 3500 and $3300 \mathrm{~cm}^{-1}$ is consistent with the change in percentage oxygen in the char. This trend shows an initial decrease in percentage oxygen and maximum absorbance at between 3500 and 3300 $\mathrm{cm}^{-1}$ from the unaltered state, followed by a slight increase in both percentage oxygen and absorbance between 3500 and $3300 \mathrm{~cm}^{-1}$ with prolonged heating. At fixed times, there is a decrease in both percentage oxygen and maximum absorbance between 3500 and $3300 \mathrm{~cm}^{-1}$ with increased charring temperature. The change in maximum absorbance between 1750 and $1700 \mathrm{~cm}^{-1}$ is consistent with the change in acid functional groups in the char. This trend shows an initial increase in percentage of acid functional groups and maximum absorbance between 1750 and $1700 \mathrm{~cm}^{-1}$ from the unaltered state, followed by a slight increase in both acid functional groups and absorbance between 1750 and $1700 \mathrm{~cm}^{-1}$ with prolonged heating. At fixed times, there is a decrease in both acid functional groups and absorbance between 1750 and $1700 \mathrm{~cm}^{-1}$ with increased charring temperature. The maximum absorbance between 1650 and $1610 \mathrm{~cm}^{-1}$ increased with the observed increase in aromatic structure previously reported (Rutherford and others, 2004).

\section{Lignin}

After heating at $250^{\circ} \mathrm{C}$ for 168 hours, lignin has lost 23.3 percent of the original mass. The percentage oxygen in the char has decreased from 26.6 percent in unaltered lignin to 23.3 percent after 168 hours. The carbon-to-oxygen ratio has increased slightly from 3.4 in unaltered lignin to 4.1 after 168 hours of charring (table 2).

Unaltered lignin has $1.23 \mathrm{meq} / \mathrm{g}$ of total acidity. When lignin was charred at $250^{\circ} \mathrm{C}$ for 168 hours, the total acidity of lignin char was $1.45 \mathrm{meq} / \mathrm{g}$. This slight increase in total acidity was due to an increase in the strong acid fraction (table 6).

The infrared reflectance spectra for lignin chars produced at $250^{\circ} \mathrm{C}$ are shown in Appendix 2, figure 2-6. The maximum absorbance between 3500 and $3300 \mathrm{~cm}^{-1}$ shows little change in the first 24 hours but decreases by 0.51 PAU by 168 hours. The maximum absorbance between 3000 and $2800 \mathrm{~cm}^{-1}$ shows similar decreases. The maximum absorbance between 1750 and $1700 \mathrm{~cm}^{-1}$ and between 1650 and $1610 \mathrm{~cm}^{-1}$ also show decreases in PAU with increased charring time which is in contrast to cellulose which shows increases in PAU between 1750 and $1700 \mathrm{~cm}^{-1}$ and between 1650 and $1610 \mathrm{~cm}^{-1}$ (table 9 and 10).

For lignin charred at $300^{\circ} \mathrm{C}$ for 8 hours, 30 percent of the total mass, 25 percent of the carbon, and 39 percent of the oxygen is lost. After 72 hours at $300^{\circ} \mathrm{C}, 41$ percent of total mass, 39 percent of the carbon, and 39 percent of the oxygen is lost. The carbon-to-oxygen ratio is 4.2 after 8 hours and 3.4 after 72 hours. This mass loss shows that there is thermal degradation occurring at $300^{\circ} \mathrm{C}$, but that it is progressing slowly (table 2).

For lignin char produced at $300^{\circ} \mathrm{C}$, total acidity after 72 hours was $2.55 \mathrm{meq} / \mathrm{g}$. This increase in total acidity, compared to the unaltered lignin, is caused by an increase in the strong acid fraction and the moderate acid and lactone fraction. The strong acid fraction increased from $0.15 \mathrm{meq} / \mathrm{g}$ for unaltered lignin to $1.18 \mathrm{meq} / \mathrm{g}$ after 72 hours, while the moderate acid and lactone fraction increased from $0.41 \mathrm{meq} / \mathrm{g}$ for unaltered lignin to $0.85 \mathrm{meq} / \mathrm{g}$ (table 6).

The infrared reflectance spectra for lignin chars produced at $300^{\circ} \mathrm{C}$ are shown in Appendix 2, figure 2-7. The maximum absorbance between 3500 and $3300 \mathrm{~cm}^{-1}$ shows a steady decrease from 0.81 PAU (unaltered) to 0.33 PAU after 72 hours. The maximum absorbance between 3000 and $2800 \mathrm{~cm}^{-1}$ shows similar decreases. The maximum absorbance between 1750 and $1700 \mathrm{~cm}^{-1}$ and between 1650 and $1610 \mathrm{~cm}^{-1}$ show decreases in PAU with increased charring time (table 10).

Charring of lignin at higher temperatures $\left(350^{\circ} \mathrm{C}\right.$ and $400^{\circ} \mathrm{C}$ ) causes increased loss for total mass, percentage carbon and percentage oxygen for any given charring time. Charring at $350^{\circ} \mathrm{C}$ for 8 hours caused the loss of 45 percent total mass, 
Table 5. The results of the Boehm titration of cellulose and cellulose char shown as the milliequivalents of total acidity and its three fractions consisting of the strong organic acid fraction, the moderate organic acid and lactone fraction, and the weak organic acid fraction.

$\left[{ }^{\circ} \mathrm{C}, \text { degrees Celsius ; meq/g, milliequivalents per gram }\right]^{* *}$

\begin{tabular}{|c|c|c|c|c|}
\hline $\begin{array}{l}\text { Charring } \\
\text { conditions }\end{array}$ & $\begin{array}{l}\text { Total Acidity } \\
\text { (meq/g) }\end{array}$ & $\begin{array}{l}\text { Strong Acid } \\
\text { Fraction } \\
\text { (meq/g) }\end{array}$ & $\begin{array}{l}\text { Moderate Acid and } \\
\text { Lactone Fraction } \\
\text { (meq/g) }\end{array}$ & $\begin{array}{c}\text { Weak Acid } \\
\text { Fraction } \\
\text { (meq/g) }\end{array}$ \\
\hline Unaltered Cellulose & 0.09 & 0.00 & 0.07 & 0.02 \\
\hline \multicolumn{5}{|c|}{ Cellulose Char } \\
\hline \multicolumn{5}{|l|}{$200^{\circ} \mathrm{C}$} \\
\hline 72 hours & 0.66 & 0.15 & 0.36 & 0.15 \\
\hline 168 hours & 1.96 & 0.41 & 0.61 & 0.94 \\
\hline \multicolumn{5}{|l|}{$250^{\circ} \mathrm{C}$} \\
\hline 8 hours & 3.93 & 0.82 & 1.14 & 1.98 \\
\hline 24 hours & 6.59 & 2.06 & 2.17 & 2.37 \\
\hline 72 hours & 8.72 & 3.52 & 2.60 & 2.60 \\
\hline 168 hours & 8.83 & 3.84 & 2.54 & 2.46 \\
\hline \multicolumn{5}{|l|}{$300^{\circ} \mathrm{C}$} \\
\hline 8 hours & 4.04 & 0.98 & 1.72 & 1.35 \\
\hline 24 hours & 6.21 & 1.81 & 2.37 & 2.04 \\
\hline 48 hours & 7.16 & 2.35 & 2.66 & 2.16 \\
\hline 72 hours & 7.38 & 2.55 & 2.44 & 2.39 \\
\hline \multicolumn{5}{|l|}{$350^{\circ} \mathrm{C}$} \\
\hline 8 hours & 3.04 & 0.88 & 1.03 & 1.14 \\
\hline 24 hours & 5.12 & 1.57 & 1.68 & 1.87 \\
\hline 48 hours & 5.02 & 1.58 & 1.84 & 1.60 \\
\hline 72 hours & 5.62 & 1.67 & 2.11 & 1.84 \\
\hline \multicolumn{5}{|l|}{$400^{\circ} \mathrm{C}$} \\
\hline 8 hours & 2.35 & 0.38 & 1.25 & 0.72 \\
\hline 24 hours & 3.25 & 0.91 & 1.18 & 1.16 \\
\hline 48 hours & 4.21 & 1.33 & 1.32 & 1.59 \\
\hline 72 hours & 4.04 & 1.21 & 1.40 & 1.44 \\
\hline
\end{tabular}

40 percent of the carbon mass, and 51 percent of the oxygen mass, while after 72 hours, 66 percent of the total mass, 67 percent of the carbon mass, and 59 percent of the oxygen mass was lost. The carbon-to-oxygen ratio is 4.2 after 8 hours and 2.8 after 72 hours. Charring at $400^{\circ} \mathrm{C}$ for 8 hours caused the loss of 62 percent total mass, 58 percent of the carbon mass, and 66 percent of the oxygen mass, while after 72 hours, 97 percent of the total mass, 97 percent of the carbon mass, and 97 percent of the oxygen mass was lost. The carbon-to-oxygen ratio was 4.1 after 8 hours and 3.5 after 72 hours (table 2).

When charred at $350^{\circ} \mathrm{C}$ and $400^{\circ} \mathrm{C}$ for 72 hours, the total acidity of lignin char was $2.58 \mathrm{meq} / \mathrm{g}$ and $3.47 \mathrm{meq} / \mathrm{g}$. When charred at $350^{\circ} \mathrm{C}$ for 72 hours, the strong acid fraction was
$1.27 \mathrm{meq} / \mathrm{g}$ and the moderate acid and lactone fraction was $1.03 \mathrm{meq} / \mathrm{g}$. Both the strong acid fraction and the moderate acid and lactone fraction have increased compared to unaltered lignin, while the weak acid fraction has decreased to 0.28 $\mathrm{meq} / \mathrm{g}$ compared to $0.68 \mathrm{meq} / \mathrm{g}$ for unaltered lignin (table 6).

The infrared reflectance spectra are shown in Appendix 2, figure 2-8, -9 , and -10 . The maximum absorbance between 3500 and $3300 \mathrm{~cm}^{-1}$ shows a sharp decrease from $0.81 \mathrm{PAU}$ (unaltered) to 0.28 and $0.12 \mathrm{PAU}$ after 1 hour when charred at $350^{\circ} \mathrm{C}$ and $400^{\circ} \mathrm{C}$. The absorbance increases slightly with longer charring times at both temperatures. The maximum absorbance between 3000 and $2800 \mathrm{~cm}^{-1}$, between 1750 and $1700 \mathrm{~cm}^{-1}$, and between 1650 and $1610 \mathrm{~cm}^{-1}$ shows similar trends (table 10). 
Table 6. The results of the Boehm titration of lignin and lignin char shown as the milliequivalents of total acidity and its three fractions consisting of the strong organic acid fraction, the moderate organic acid and lactone fraction, and the weak organic acid fraction.

[ ${ }^{\circ} \mathrm{C}$, degrees Celsius ; meq/g, milliequivalents per gram]

\begin{tabular}{|c|c|c|c|c|}
\hline $\begin{array}{l}\text { Charring } \\
\text { conditions }\end{array}$ & $\begin{array}{l}\text { Total Acidity } \\
\text { (meq/g) }\end{array}$ & $\begin{array}{c}\text { Strong Acid } \\
\text { Fraction (meq/g) }\end{array}$ & $\begin{array}{l}\text { Moderate Acid and } \\
\text { Lactone Fraction } \\
\text { (meq/g) }\end{array}$ & $\begin{array}{l}\text { Weak Acid } \\
\text { Fraction } \\
\text { (meq/g) }\end{array}$ \\
\hline Unaltered Lignin & 1.23 & 0.15 & 0.41 & 0.68 \\
\hline \multicolumn{5}{|c|}{ Lignin Char } \\
\hline \multicolumn{5}{|l|}{$250^{\circ} \mathrm{C}$} \\
\hline 72 hours & 0.97 & 0.18 & 0.20 & 0.60 \\
\hline 168 hours & 1.45 & 0.49 & 0.37 & 0.59 \\
\hline \multicolumn{5}{|l|}{$300^{\circ} \mathrm{C}$} \\
\hline 24 hours & 1.18 & 0.17 & 0.19 & 0.83 \\
\hline 48 hours & 1.51 & 0.65 & 0.66 & 0.20 \\
\hline 72 hours & 2.55 & 1.18 & 0.85 & 0.52 \\
\hline \multicolumn{5}{|l|}{$350^{\circ} \mathrm{C}$} \\
\hline 24 hours & 1.23 & 0.62 & 0.32 & 0.29 \\
\hline 48 hours & 3.64 & 1.65 & 1.10 & 0.89 \\
\hline 72 hours & 2.58 & 1.27 & 1.03 & 0.28 \\
\hline \multicolumn{5}{|l|}{$400^{\circ} \mathrm{C}$} \\
\hline 24 hours & 2.55 & 0.82 & 0.66 & 1.08 \\
\hline 48 hours & 2.42 & 1.25 & 1.17 & 0 \\
\hline 72 hours & 3.47 & 1.97 & 1.20 & 1.31 \\
\hline \multicolumn{5}{|l|}{$450^{\circ} \mathrm{C}$} \\
\hline 24 hours & 2.24 & 0.62 & 0.86 & 0.76 \\
\hline
\end{tabular}

\section{Pine Wood}

Pine wood charred at $250^{\circ} \mathrm{C}$ for 8 hours has lost 44 percent total mass, 31 percent carbon, and 57 percent oxygen. After 168 hours of charring at $250^{\circ} \mathrm{C}$, pine wood has lost 70 percent total mass, 63 percent of carbon mass, and 75 percent of oxygen mass. The oxygen to carbon ratio for unaltered pine wood is 1.6. The carbon-to-oxygen ratios for chars produced at $250^{\circ} \mathrm{C}$ for 8 and 168 hours are 2.6 and 2.4, respectively (table 3 ).

Unaltered pine wood has $0.89 \mathrm{meq} / \mathrm{g}$ total acidity. At $250^{\circ} \mathrm{C}$, the total acidities in pine wood charred for 8 and 168 hours were $2.93 \mathrm{meq} / \mathrm{g}$ and $7.83 \mathrm{meq} / \mathrm{g}$, respectively. After 8 hours, the percentages of the strong acid fraction, the moderate acid and lactone fraction, and weak acid fraction in unaltered pine wood are 6,13 and 81 percent, respectively. After 168 hours, the percentages are 36,33 , and 31 percent respectively. Although all three fractions increase with charring, the weak acid fraction reached a maximum in the first 8 hours while the strong acid fraction increases steadily with increased charring time. The largest increase of total acidity observed in pine wood char was for charring at $250^{\circ} \mathrm{C}$ for 168 hours, to approximately seven times the total acidity of unaltered pine wood (table 7).

The infrared reflectance spectra for pine wood chars produced at $250^{\circ} \mathrm{C}$ are shown in Appendix 2, figure 2-11. The maximum absorbance between 3500 and 3300 and between 3000 and $2800 \mathrm{~cm}^{-1}$ shows little change in the first hour but decreases by 0.37 and 0.25 PAU after 168 hours. After 168 hours, the maximum absorbance between 1750 and $1700 \mathrm{~cm}^{-1}$ has increased by $0.55 \mathrm{PAU}$. There is a consistent shift in band location from 1740 to $1750 \mathrm{~cm}^{-1}$ with prolonged charring. The maximum absorbance between 1650 and $1610 \mathrm{~cm}^{-1}$ increases by 0.42 PAU after 168 hours. In the region between 1400 and $900 \mathrm{~cm}^{-1}$, the individual bands coalesce into one broad band and decrease in intensity slightly by 168 hours (table 11). This is consistent with the changes observed for cellulose charred under these conditions.

When charred at $300^{\circ} \mathrm{C}$ for 8 hours, pine wood has lost 67 percent total mass, 54 percent of carbon mass, and 80 percent of oxygen mass. After 72 hours of charring at $300^{\circ} \mathrm{C}$, 83 percent total mass, 78 percent of carbon mass, and 87 percent of oxygen mass have been lost. The 
Table 7. The results of the Boehm titration of pine wood and pine wood char shown as the milliequivalents of total acidity and its three fractions consisting of the strong organic acid fraction, the moderate organic acid and lactone fraction, and the weak organic acid fraction.

[ ${ }^{\circ} \mathrm{C}$, degrees Celsius ; meq/g, milliequivalents per gram]

\begin{tabular}{|c|c|c|c|c|}
\hline $\begin{array}{l}\text { Charring } \\
\text { conditions }\end{array}$ & $\begin{array}{l}\text { Total Acidity } \\
\text { (meq/g) }\end{array}$ & $\begin{array}{l}\text { Strong Acid } \\
\text { Fraction } \\
(\text { meq } / g)\end{array}$ & $\begin{array}{l}\text { Moderate Acid and } \\
\text { Lactone Fraction } \\
\text { (meq/g) }\end{array}$ & $\begin{array}{l}\text { Weak Acid } \\
\text { Fraction } \\
\text { (meq/g) }\end{array}$ \\
\hline Unaltered Pine Wood & 0.89 & 0.05 & 0.12 & 0.72 \\
\hline \multicolumn{5}{|c|}{ Pine Wood Char } \\
\hline \multicolumn{5}{|l|}{$250^{\circ} \mathrm{C}$} \\
\hline 8 hours & 2.93 & 0.32 & 0.20 & 2.41 \\
\hline 24 hours & 5.40 & 1.09 & 2.02 & 2.29 \\
\hline 72 hours & 7.10 & 2.16 & 2.61 & 2.34 \\
\hline 168 hours & 7.83 & 2.80 & 2.58 & 2.46 \\
\hline \multicolumn{5}{|l|}{$300^{\circ} \mathrm{C}$} \\
\hline 1 hour & 2.47 & 0.15 & 0.70 & 1.62 \\
\hline 8 hours & 4.39 & 1.02 & 1.60 & 1.77 \\
\hline 24 hours & 5.49 & 1.48 & 2.06 & 1.94 \\
\hline 48 hours & 6.09 & 1.68 & 2.15 & 2.26 \\
\hline 72 hours & 5.88 & 1.83 & 1.98 & 2.08 \\
\hline \multicolumn{5}{|l|}{$350^{\circ} \mathrm{C}$} \\
\hline 8 hours & 2.38 & 0.57 & 0.89 & 0.93 \\
\hline \multicolumn{5}{|l|}{$400^{\circ} \mathrm{C}$} \\
\hline 8 hours & 1.35 & 0.18 & 0.49 & 0.68 \\
\hline
\end{tabular}

carbon-to-oxygen ratio for chars produced at $300^{\circ} \mathrm{C}$ for 8 and 72 hours are 3.5 and 2.7 , respectively (table 3 ).

For pine wood chars produced at $300^{\circ} \mathrm{C}$ for 8 and 72 hours, the total acidities are 4.39 and $5.88 \mathrm{meq} / \mathrm{g}$, respectively. The percentages of strong acid fraction, moderate acid and lactone fraction and weak acid fraction after 72 hours, are 31,34 , and 35 percent, respectively (table 7).

The infrared reflectance spectra for pine wood charred at $300^{\circ} \mathrm{C}$ are shown in Appendix 2, figure 2-12. The maximum absorbances between 3500 and $3300 \mathrm{~cm}^{-1}$ and between 3000 and $2800 \mathrm{~cm}^{-1}$ decrease to 0.60 and 0.45 PAU, respectively, after 168 hours. After 168 hours, the maximum absorbance between 1750 and $1700 \mathrm{~cm}^{-1}$ has increased to $1.18 \mathrm{PAU}$. The maximum absorbance between 1650 and $1610 \mathrm{~cm}^{-1}$ increases to 1.09 PAU after 168 hours (table 11).

\section{Pine Bark}

Pine bark charred at $250^{\circ} \mathrm{C}$ for 8 hours has lost 40 percent total mass, 28 percent carbon, and 53 percent oxygen. After 168 hours of charring at $250^{\circ} \mathrm{C}$, pine bark has lost 66 percent total mass, 63 percent of carbon mass, and 71 percent of oxygen mass. Unaltered pine bark contains 43 percent oxygen by weight. The percentage oxygen in the char decreases to 34 percent at 8 hours and then rises slightly, to 39 percent at 168 hours. For unaltered pine bark, the carbon-to-oxygen atomic ratio is 1.6. The carbon-to-oxygen ratio is 2.5 after 8 hours and 2.1 after 168 hours (table 4 ).

Unaltered pine bark has $1.57 \mathrm{meq} / \mathrm{g}$ of total acidity. For pine bark charred at $250^{\circ} \mathrm{C}$ for 8 and 168 hours, the total acidities are 2.70 and $5.96 \mathrm{meq} / \mathrm{g}$, respectively. The maximum increase of total acidity observed in pine bark char was for $250^{\circ} \mathrm{C}$ for 168 hours and was approximately four times the total acidity of unaltered pine bark. The percentages of the strong acid fraction, the moderate acid and lactone fraction, and weak acid fraction are 9, 19, and 73 percent, respectively, for charring for 8 hours. After 168 hours, the percentages of the strong acid fraction, the moderate acid and lactone fraction, and weak acid fraction are 27, 34, and 39 percent, respectively (table 8).

The infrared reflectance spectra for pine bark charred at $250^{\circ} \mathrm{C}$ are shown in Appendix 2, figure 2-15. The maximum absorbances between 3500 and 3300 and between 3000 and $2800 \mathrm{~cm}^{-1}$ show little change in the first hour but decreases by 0.33 and 0.25 PAU after 168 hours. After 168 hours, the maximum absorbance between 1750 and $1700 \mathrm{~cm}^{-1}$ has 
Table 8. The results of the Boehm titration of pine bark and pine bark char shown as the milliequivalents of total acidity and its three fractions consisting of the strong organic acid fraction, the moderate organic acid and lactone fraction, and the weak organic acid fraction.

$\left[{ }^{\circ} \mathrm{C}\right.$, degrees Celsius ; meq/g, milliequivalents per gram $]$

\begin{tabular}{|c|c|c|c|c|}
\hline $\begin{array}{l}\text { Charring } \\
\text { conditions }\end{array}$ & $\begin{array}{l}\text { Total Acidity } \\
\text { (meq/g) }\end{array}$ & $\begin{array}{l}\text { Strong Acid } \\
\text { Fraction } \\
\text { (meq/g) }\end{array}$ & $\begin{array}{l}\text { Moderate Acid and } \\
\text { Lactone Fraction } \\
\text { (meq/g) }\end{array}$ & $\begin{array}{l}\text { Weak Acid } \\
\text { Fraction } \\
\text { (meq/g) }\end{array}$ \\
\hline Unaltered Pine Bark & 1.57 & 0.18 & 0.67 & 0.73 \\
\hline \multicolumn{5}{|c|}{ Pine Bark Char } \\
\hline \multicolumn{5}{|l|}{$250^{\circ} \mathrm{C}$} \\
\hline 8 hours & 2.70 & 0.24 & 0.50 & 1.96 \\
\hline 24 hours & 3.97 & 0.63 & 1.38 & 1.97 \\
\hline 72 hours & 5.47 & 1.29 & 1.70 & 2.49 \\
\hline 168 hours & 5.96 & 1.60 & 2.03 & 2.33 \\
\hline \multicolumn{5}{|l|}{$300^{\circ} \mathrm{C}$} \\
\hline 1 hour & 2.24 & 0.09 & 0.83 & 1.33 \\
\hline 8 hours & 2.38 & 0.27 & 0.65 & 1.46 \\
\hline 24 hours & 2.86 & 0.45 & 0.91 & 1.51 \\
\hline 48 hours & 3.62 & 0.45 & 1.15 & 2.03 \\
\hline 72 hours & 3.52 & 0.25 & 1.23 & 2.05 \\
\hline \multicolumn{5}{|l|}{$350^{\circ} \mathrm{C}$} \\
\hline 8 hours & 1.59 & 0.00 & 0.41 & 1.19 \\
\hline \multicolumn{5}{|l|}{$400^{\circ} \mathrm{C}$} \\
\hline 8 hours & 0.47 & 0.00 & 0.24 & 0.23 \\
\hline
\end{tabular}

increased by 0.49 PAU, while the maximum absorbance between 1650 and $1610 \mathrm{~cm}^{-1}$ increases by 0.11 PAU (table 12).

When charred at $300^{\circ} \mathrm{C}$ for 8 hours, pine bark has lost 53 percent total mass, 42 percent of carbon mass, and 65 percent of oxygen mass. After 72 hours of charring at $300^{\circ} \mathrm{C}, 82$ percent total mass, 83 percent of carbon mass, and 85 percent of oxygen mass has been lost. At $300^{\circ} \mathrm{C}$, the percentage oxygen in the char reached a minimum of 30 percent after 1 hour of charring and then increased to 40 percent after 72 hours. At $300^{\circ} \mathrm{C}$, the carbon-to-oxygen atomic ratio maximized at 2.9 after 1 hour and then decreased to 1.9 after 72 hours (table 4 ).

For pine bark charred at $300^{\circ} \mathrm{C}$ for 8 and 72 hours, the total acidities are 2.24 and $3.52 \mathrm{meq} / \mathrm{g}$, respectively. The percentages of the strong acid fraction, the moderate acid and lactone fraction, and weak acid fraction are 11, 27, and 61 percent, respectively, for charring for 8 hours. After 168 hours, the percentages of the strong acid fraction, the moderate acid and lactone fraction, and weak acid fraction are 7, 35, and 58 percent, respectively (table 8).

\section{Trends in Compositional Change and Implications for Development of Acid Functional Groups}

Pyrolysis reactions lead to the formation of the so-called char/charcoal black carbon fraction in soils formed by the charring of biomass mainly of plant origin. This black carbon is the least studied component of soil organic carbon. Although there have been numerous studies of high-surface-area chars, which have a long history as sorbents, there has been little study of low temperature charring of natural organic matter that is expected to make up black carbon in soils.

Simoneit (2002) pointed out that during the heating of wood, the sequence of decomposition with increasing temperature is hydrolysis, oxidation, dehydration, and finally pyrolysis. Soil chars are typically highly carboxylated, linearly fused, and/or highly condensed aromatic polymers (Kramer and others, 2004; Rutherford and others, 2004). Shafizadeh (1984) pointed out: "The production of volatiles leaves a solid residue 
Table 9. The pseudo-absorbance of selected absorbance bands for diffuse reflectance infrared spectroscopy of cellulose and cellulose char.

[The absorbance is given in pseudo-absorbance units. The number in parenthesis is the wave number for the highest value of the absorbance band. ${ }^{\circ} \mathrm{C}$, degrees Celsius ; --, not determined]

\begin{tabular}{|c|c|c|c|c|c|}
\hline \multirow[b]{2}{*}{$\begin{array}{l}\text { Charring Time } \\
\text { (hours) }\end{array}$} & \multicolumn{5}{|c|}{ Charring Temperature (degrees Celsius) } \\
\hline & $200^{\circ} \mathrm{C}$ & $250^{\circ} \mathrm{C}$ & $300^{\circ} \mathrm{C}$ & $350^{\circ} \mathrm{C}$ & $400^{\circ} \mathrm{C}$ \\
\hline \multicolumn{6}{|c|}{ Region $1\left(3500-3300 \mathrm{~cm}^{-1}\right)$} \\
\hline \multicolumn{6}{|c|}{ Unaltered Cellulose: 1.31 (3449) } \\
\hline 1 & -- & $1.53(3435)$ & $0.55(3422)$ & $0.44(3443)$ & $0.31(3518)$ \\
\hline 8 & -- & $0.77(3418)$ & $0.56(3414)$ & $0.42(3416)$ & $0.24(3493)$ \\
\hline 24 & -- & $0.82(3345)$ & $0.72(3327)$ & $0.53(3331)$ & $0.25(3333)$ \\
\hline 48 & -- & $0.77(3343)$ & $0.70(3329)$ & $0.60(3321)$ & $0.33(3354)$ \\
\hline 72 & $1.40(3449)$ & $0.87(3327)$ & $0.76(3329)$ & $0.59(3310)$ & $0.28(3333)$ \\
\hline 168 & $1.44(3408)$ & $0.83(3319)$ & -- & -- & -- \\
\hline \multicolumn{6}{|c|}{ Region $2\left(3000-2800 \mathrm{~cm}^{-1}\right)$} \\
\hline \multicolumn{6}{|c|}{ Unaltered Cellulose: 0.97 (2901) } \\
\hline 1 & -- & $1.09(2901)$ & $0.51(2928)$ & $0.42(2926)$ & $0.27(2924)$ \\
\hline 8 & -- & $0.58(2901)$ & $0.45(2930)$ & $0.31(2926)$ & $0.15(2924)$ \\
\hline 24 & -- & $0.55(2901)$ & $0.51(2930)$ & $0.37(2926)$ & $0.16(2924)$ \\
\hline 48 & -- & $0.52(2901)$ & $0.50(2930)$ & $0.43(2926)$ & $0.24(2924)$ \\
\hline 72 & $1.01(2901)$ & $0.58(2901)$ & $0.53(2930)$ & $0.43(2926)$ & $0.20(2924)$ \\
\hline 168 & $1.05(2901)$ & $0.57(2901)$ & -- & -- & -- \\
\hline \multicolumn{6}{|c|}{ Region $3\left(1750-1700 \mathrm{~cm}^{-1}\right)$} \\
\hline \multicolumn{6}{|c|}{ Unaltered Cellulose: 0.17 (1722) } \\
\hline 1 & -- & $0.40(1711)$ & $1.20(1711)$ & $1.09(1711)$ & $0.86(1709)$ \\
\hline 8 & -- & $1.50(1728)$ & $1.23(1721)$ & $1.07(1717)$ & $0.88(1715)$ \\
\hline 24 & -- & $1.48(1749)$ & $1.36(1753)$ & $1.27(1753)$ & $0.98(1759)$ \\
\hline 48 & -- & $1.42(1749)$ & $1.41(1755)$ & $1.36(1757)$ & $1.18(1761)$ \\
\hline 72 & $0.67(1722)$ & $1.50(1749)$ & $1.48(1755)$ & $1.37(1759)$ & $1.14(1763)$ \\
\hline 168 & $1.10(1726)$ & $1.41(1755)$ & -- & -- & -- \\
\hline \multicolumn{6}{|c|}{ Region $4\left(1650-1610 \mathrm{~cm}^{-1}\right)$} \\
\hline \multicolumn{6}{|c|}{ Unaltered Cellulose: 0.37 (1636) } \\
\hline 1 & -- & $0.37(1626)$ & $1.10(1605)$ & $1.06(1605)$ & $0.93(1603)$ \\
\hline 8 & -- & $1.28(1609)$ & 1.17 (1607) & $1.14(1607)$ & $1.01(1605)$ \\
\hline 24 & -- & $1.29(1614)$ & $1.23(1612)$ & $1.23(1612)$ & $1.04(1611)$ \\
\hline 48 & -- & $1.24(1612)$ & $1.28(1614)$ & $1.29(1614)$ & $1.23(1614)$ \\
\hline 72 & $0.52(1626)$ & $1.31(1616)$ & $1.34(1612)$ & $1.31(1616)$ & $1.19(1618)$ \\
\hline 168 & $0.82(1626)$ & $1.23(1618)$ & -- & -- & -- \\
\hline
\end{tabular}

that is neither intact substrate nor pure carbon, but a different material at various stages of charring and carbonization. The intermediate chars are characterized by the functional groups present (including aromatic and olefinic structures); a high concentration of free spins trapped in a rigid structure or stabilized by aromatic and olefinic structures; a large surface area; and high degree of reactivity."

The pyrolysis of cellulose, the most abundant constituent biomass, has been studied more extensively than that of any other biomass constituent. Shafizadeh $(1982,1984)$ has delineated two different pathways for cellulose pyrolysis. At temperatures below about $300^{\circ} \mathrm{C}$ bond scission, formation of free radicals, dehydration, and formation of carbonyl, carboxyl, and hydroperoxide groups predominate. These reactions are followed by production of carbon monoxide, carbon dioxide, and char. The carbon monoxide is apparently the result of decarbonylation and the carbon dioxide of decarboxylation. At temperatures above $300^{\circ} \mathrm{C}$ bond cleavage 


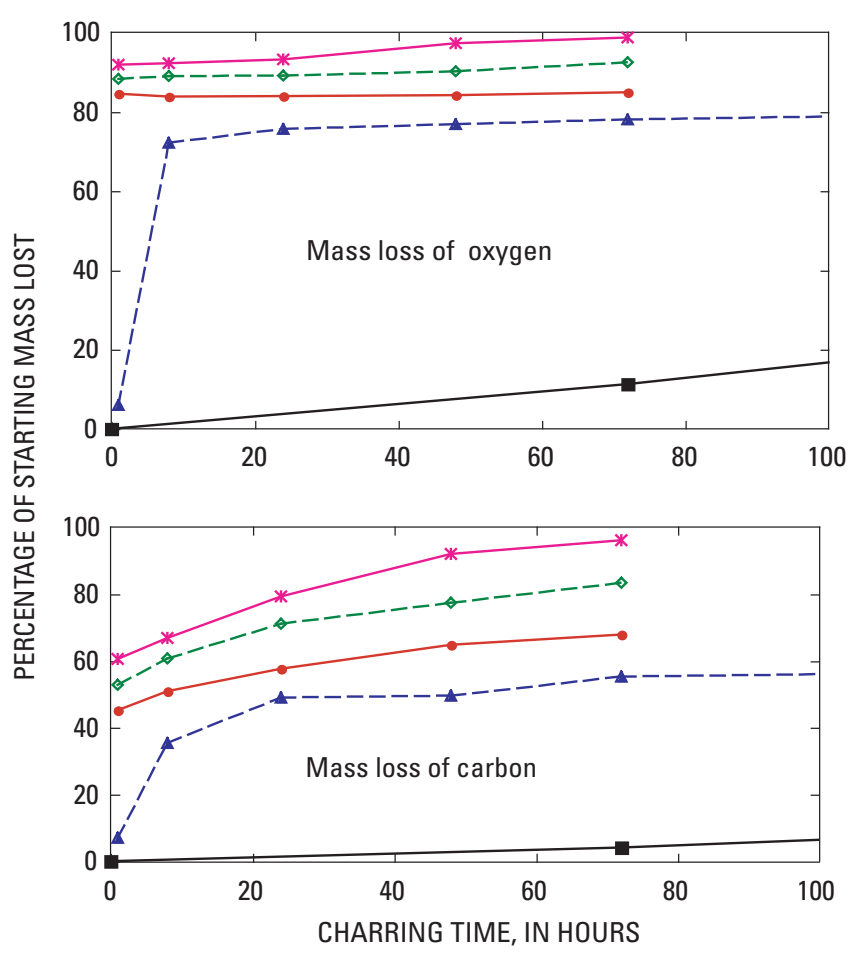

EXPLANATION

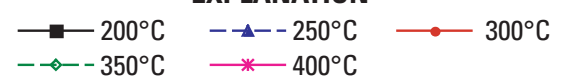

Figure 2. The mass loss of carbon and oxygen during the charring of cellulose at various charring times and temperatures.

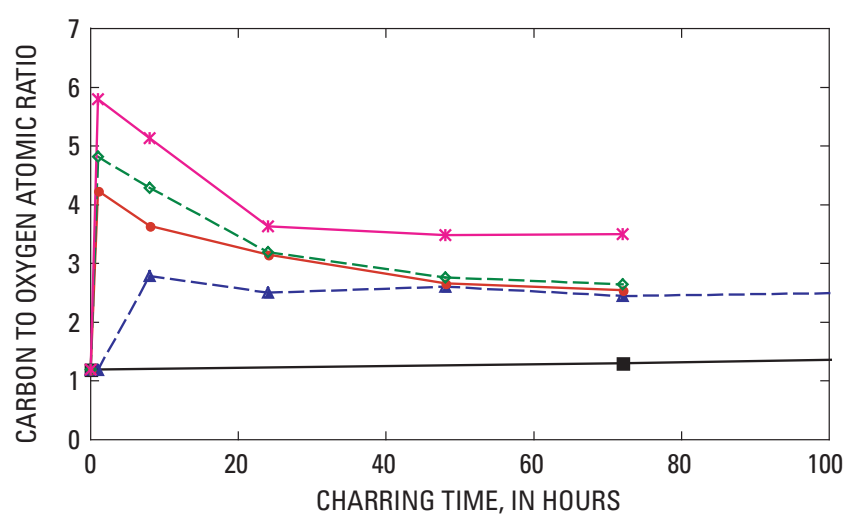

EXPLANATION

$\longrightarrow 200^{\circ} \mathrm{C} \rightarrow \rightarrow--250^{\circ} \mathrm{C} \longrightarrow 300^{\circ} \mathrm{C} \rightarrow-350^{\circ} \mathrm{C} \rightarrow 400^{\circ} \mathrm{C}$

Figure 3. The carbon-to-oxygen atomic ratio of cellulose chars at various charring times and temperatures.

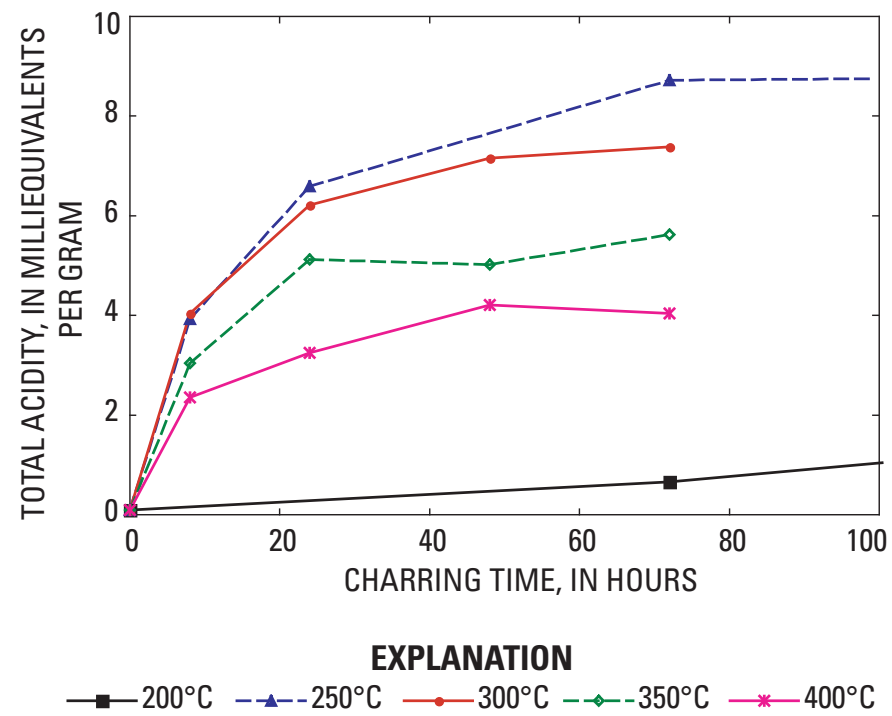

Figure 4. The total acidity of cellulose chars at various charring times and temperatures.

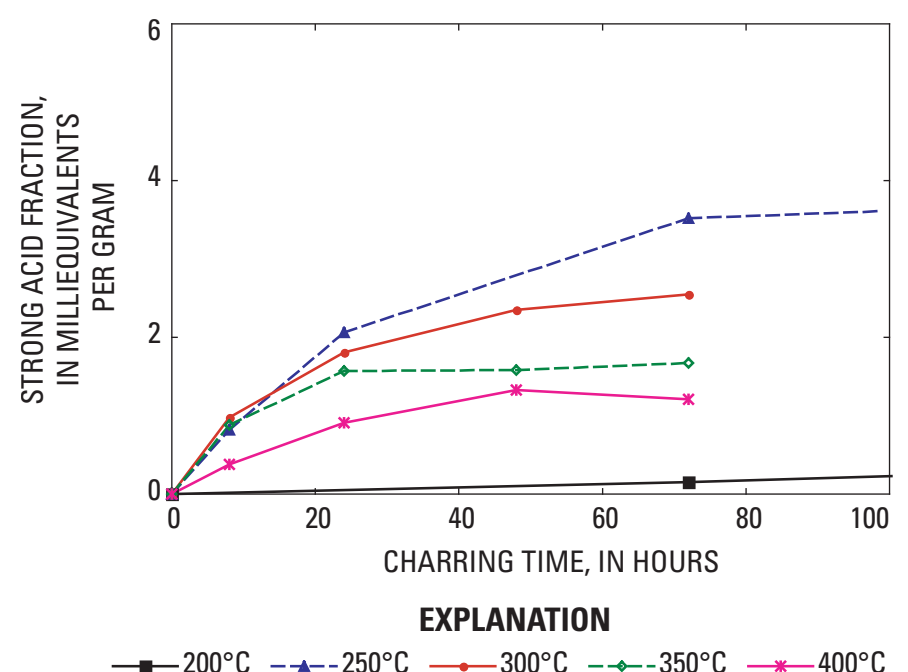

Figure 5. The strong organic acid fraction of cellulose chars at various charring times and temperatures. 


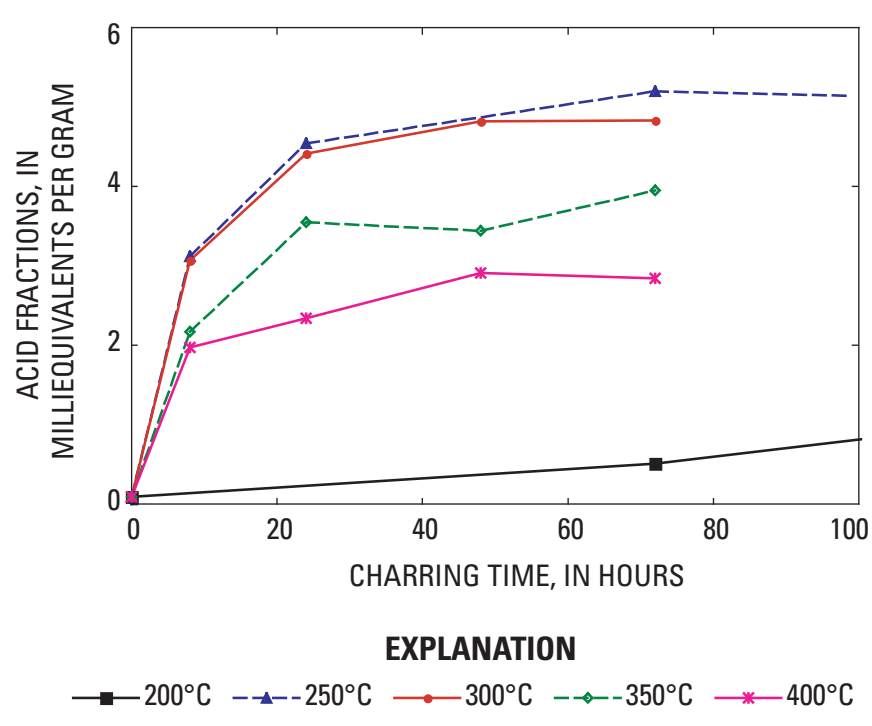

Figure 6. The sum of the moderate acid and lactone fraction and weak organic acid fraction of cellulose chars at various charring times and temperatures.

by transglycosylation, bond fission, and disproportionation reactions take place. This second pathway leads to the formation of anhydro sugars such as levoglucosan by dehydration. (See Nimlos and others, 2003, for a detailed discussion of dehydration of carbohydrates.) Sanders and others (2003) have developed a more detailed model of the saccharides. They found that at temperatures between 300 and $600^{\circ} \mathrm{C}$ low-molecular weight oxygenated compounds such as anhydro sugars and simple aromatic compounds are formed. At higher temperatures polynuclear aromatic hydrocarbons are produced. However, McGrath and others (2003) found that polynuclear aromatic hydrocarbons form between 300 and $650^{\circ} \mathrm{C}$. Rutherford and others (2004) have shown that polynuclear aromatic hydrocarbons form as low as $250^{\circ} \mathrm{C}$. Polynuclear aromatic hydrocarbons also are formed from pyrolysis of lignin (Sharma and Hajaligol, 2003) and amino acids (Sharma and others, 2003).

This study used purified cellulose and lignin because they are the most abundant components of plant materials. Wood and bark are mixtures of these end-members. Soft wood is composed of $64.5 \pm 4.6$ percent carbohydrates of which $43.7 \pm$ 2.6 percent is cellulose. Lignin makes up $28.8 \pm 2.6$ percent of a softwood (Pettersen, 1984). Bark also is composed primarily of carbohydrates and lignin but with a lower percentage of carbohydrates and a higher percentage of lignin than in the wood.

As was shown in a previous study (Rutherford and others, 2004), the loss of material during charring is a general indicator of thermal decomposition but does not give a clear picture of the decomposition reactions. Aliphatic carbon is lost rapidly during early thermal decomposition, while aromatic carbon is initially being formed. Prolonged heating results in loss of aromatic carbons at temperatures above $300^{\circ} \mathrm{C}$. The rate of loss of carbon and oxygen are not proportional. Oxygen is lost preferentially to carbon during initial decomposition for all materials. These changes are reflected in the carbon-tooxygen atomic $(\mathrm{C} / \mathrm{O})$ ratios, which reach a maximum in the first hours of charring, and then decrease with prolonged charring. As charring temperatures increase, thermal degradation occurs more rapidly and a greater percentage of total and oxygen mass is lost. The discrepancy between the loss of carbon and oxygen is magnified, with higher $\mathrm{C} / \mathrm{O}$ ratios being reached at short charring times.

There is a general correlation of rapid oxygen loss during early decomposition with loss of aliphatic carbon, as determined in the previous study (Rutherford and others, 2004). If the labile oxygen is associated with the aliphatic carbon, then the recalcitrant oxygen lost with prolonged heating will be associated with the loss of aromatic carbon. In the case of cellulose, there is no aromatic carbon present in the starting material. This aromatic carbon must be formed from the remaining aliphatic carbon. The oxygen functional groups may be attached to aromatic carbon at this time. As the charring temperature is increased, the percentage oxygen decreases. It is speculated that the lower charring temperature and longer reaction times allow more oxygen functional groups to become attached to aromatic carbons.

For cellulose at all charring temperatures, total acidity increases with charring time. Total acidity reaches a maximum at $250^{\circ} \mathrm{C}$ with long charring times for cellulose and cellulose containing materials (wood and bark). This is shown in figure 7 . Even though unaltered lignin starts out with approximately 10 times more total acidity than cellulose, lignin char consistently has less total acidity than cellulose char. The total acidity content of the chars for a fixed time and temperature decreased in the order cellulose char $>$ pine wood char $>$ pine bark char $>$ lignin char. The total acidity for lignin char increased steadily to $400^{\circ} \mathrm{C}$. With charring at $400^{\circ} \mathrm{C}$ for 72 hours, the difference in total acidity due to starting material has essentially disappeared.

The largest increase observed for total acidity in cel-

lulose char was approximately a factor of 80 times the total acidity of unaltered cellulose, while the largest increase for lignin char was approximately a factor of three times the total acidity of unaltered lignin. The maximum increase in total acidity observed in pine wood char was approximately seven times the total acidity of unaltered pine wood while the maximum increase total acidity observed in pine bark char was approximately four times the total acidity of unaltered pine bark. This suggests that cellulose is the major contributor to acid functional group development in chars of wood and bark.

For cellulose, pine wood, and pine bark, the increase in total acidity results from an increase in the three fractions of acidity (strong acid fraction, moderate acid and lactone fraction, and weak acid fraction). The increase in total acidity for lignin is a result of an increase in the strong acid fraction and the moderate acid and lactone fraction. 


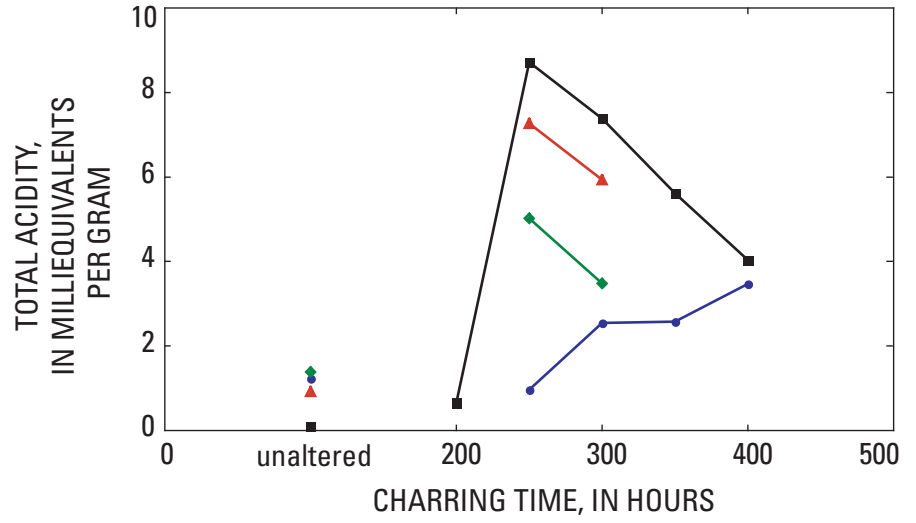

EXPLANATION $\rightarrow$ Cellulose $\rightarrow$ Lignin $\rightarrow$ Pine Wood $\rightarrow$ Pine Bark

Figure 7. The total acidity of cellulose, lignin, pine wood, and pine bark chars after 72 hours of charring at various temperatures.

Of the three fractions of acidity, the strong acid fraction increased the most but takes longer to develop for cellulosecontaining materials. The weak acid fraction appears to develop the fastest and reaches a maximum within the first 8 hours of charring.

Each of the fractions of acid functional groups in cellulose, pine wood, and pine bark follow the same trend as total acidity. For charring at a fixed time, the maximum increase occurs at $250^{\circ} \mathrm{C}$ and decrease with increasing temperature above $250^{\circ} \mathrm{C}$.

The oxygen content of a char is not a good indicator of acid functional groups. The percentage oxygen initially decreased at the onset of charring, then increased slightly with charring time. The acid functional group contents of the chars increased uniformly with increased charring time. This indicates that once the initial loss of labile oxygen is complete, acid functional groups continue to be formed and would indicate that rearrangement of oxygen within the char structure is occurring with prolonged charring.

The difference in acid functional group formation in cellulose and lignin suggests that in cellulose, as aliphatic carbon is being converted to aromatic carbon, a percentage of the oxygen also is converted to acid functional groups on the aromatic carbon when charred at low temperature. Charring at higher temperatures either reduces the number of acid functional groups formed or removes them once they are formed. In lignin, there is less oxygen relative to carbon in the uncharred material, and it is not clear whether additional acid functional groups are being formed or if they already existed and are being concentrated by the charring process.

It was observed for all samples that thermal degradation caused reduction of the broad band in the region between 3500 and $3300 \mathrm{~cm}^{-1}$ and of the sharp bands between 3000 and $2800 \mathrm{~cm}^{-1}$ and increases in the intensities of the sharp bands between about 1750 and $1700 \mathrm{~cm}^{-1}$. The individual sharp bands between 1400 and $900 \mathrm{~cm}^{-1}$ increased in width with increasing temperature until they coalesced into a single broad band. The broad band between 3500 and $3300 \mathrm{~cm}^{-1}$ is characteristic of the $\mathrm{OH}$ stretching mode. The stretching modes of $\mathrm{CH}_{3}, \mathrm{CH}_{2}$, and $\mathrm{CH}$ groups are represented by sharp bands near 2962 and $2872 \mathrm{~cm}^{-1}, 2926$ and 2853 $\mathrm{cm}^{-1}$, and $2890 \mathrm{~cm}^{-1}$ respectively; the stretching mode of aromatic $\mathrm{CH}$ groups is located at approximately 3030 $\mathrm{cm}^{-1}$. The sharp bands between about 1750 and $1700 \mathrm{~cm}^{-1}$ most likely represent carbonyl-stretching bands of lactones and carboxylic acids. The carbonyl groups of lactones generally have bands between about 1735 and $1800 \mathrm{~cm}^{-1}$; saturated aliphatic acids occur in the region between 1725 and $1700 \mathrm{~cm}^{-1}$, and aryl acids occur between 1700 and $1680 \mathrm{~cm}^{-1}$. Carbonyl groups of esters and ketones also are found in the region between 1750 and $1690 \mathrm{~cm}^{-1}$ and may be present in some of the samples. The band between 1650 and $1610 \mathrm{~cm}^{-1}$ represents skeletal vibrations of fused-ring aromatic structures and conjugated ketones. The growth of this band during charring reflects the increase in aromaticity and the possible presence of hydrogen bonded quinones. Carboxylate groups have two carbonyl stretching modes-an asymmetric and a symmetric mode. The asymmetric mode is represented by a band between 1610 and $1550 \mathrm{~cm}^{-1}$ and the symmetric mode by a band between 1400 and $1300 \mathrm{~cm}^{-1}$. The individual sharp bands between 1400 and $900 \mathrm{~cm}^{-1}$ are characteristic of the lignin and cellulose components of wood. These bands mostly represent $\mathrm{OH}$ deformations and $\mathrm{CO}$ stretching modes of alcohols and phenols. Faix (1991) has shown that lignin has a number of well-resolved bands in this region. For example, a prominent band near $1127 \mathrm{~cm}^{-1}$ is indicative of methoxy groups of guaiacyl and syringyl units in the lignin structure. The bands between 1070 and $1030 \mathrm{~cm}^{-1}$ arise from alcoholic groups in carbohydrates (Colthup and others, 1990).

\section{Summary}

This report provides data on acid functional groups and lactones in charcoals and on how the content of these groups varies during thermals degradation with variation of charring time and temperature. Chars were created from purified cellulose, purified lignin, pine wood, and pine bark. The charring temperatures and charring duration were controlled in a laboratory furnace with an inert atmosphere and ranged from 200 degrees Celsius $\left({ }^{\circ} \mathrm{C}\right.$ ) to $500^{\circ} \mathrm{C}$ and for 1 hour to 168 hours charring time.

The acid functional groups and lactones of these chars were measured by using the Boehm titration method. This method measures the amount of $\mathrm{NaOH}, \mathrm{NaHCO}_{3}$, and $\mathrm{Na}_{2} \mathrm{CO}_{3}$ neutralized by the char and allows the determination of total acidity and the fraction of acidity associated with the strong acid fraction, the moderate acid and lactone fraction, and weak acid fraction. The total acidity of chars from cellulose 
Table 10. The pseudo-absorbance of selected absorbance bands for diffuse reflectance infrared spectroscopy of lignin and lignin char.

[The absorbance is given in pseudo-absorbance units. The number in parenthesis is the wave number for the highest value of the absorbance band. ${ }^{\circ} \mathrm{C}$, degrees Celsius ; --, not determined]

\begin{tabular}{|c|c|c|c|c|}
\hline \multirow[b]{2}{*}{ Charring Time (hours) } & \multicolumn{4}{|c|}{ Charring Temperature (degrees Celsius) } \\
\hline & $250^{\circ} \mathrm{C}$ & $300^{\circ} \mathrm{C}$ & $350^{\circ} \mathrm{C}$ & $400^{\circ} \mathrm{C}$ \\
\hline \multicolumn{5}{|c|}{ Region $1\left(3500-3300 \mathrm{~cm}^{-1}\right)$} \\
\hline \multicolumn{5}{|c|}{ Unaltered Lignin: 0.81 (3458) } \\
\hline 1 & -- & $0.70(3512)$ & $0.28(3528)$ & $0.12(3510)$ \\
\hline 8 & -- & $0.46(3516)$ & $0.20(3316)$ & $0.27(3092)$ \\
\hline 24 & $0.81(3514)$ & $0.39(3558)$ & $0.39(3283)$ & $0.45(3092)$ \\
\hline 48 & -- & $0.31(3345)$ & $0.45(3262)$ & $0.35(3088)$ \\
\hline 72 & $0.56(3512)$ & $0.33(3248)$ & $0.57(3250)$ & $0.36(3092)$ \\
\hline 168 & $0.30(3520)$ & -- & -- & -- \\
\hline \multicolumn{5}{|c|}{ Region $2\left(3000-2800 \mathrm{~cm}^{-1}\right)$} \\
\hline \multicolumn{5}{|c|}{ Unaltered Lignin: 0.88 (2938) } \\
\hline 1 & -- & $0.69(2938)$ & $0.27(2936)$ & $0.09(2928)$ \\
\hline 8 & -- & $0.45(2938)$ & $0.17(2938)$ & $0.21(2928)$ \\
\hline 24 & $0.83(2938)$ & $0.37(2940)$ & $0.32(2938)$ & $0.37(2928)$ \\
\hline 48 & -- & $0.28(2940)$ & $0.39(2938)$ & $0.26(2928)$ \\
\hline 72 & $0.57(2940)$ & $0.31(2959)$ & $0.50(2938)$ & $0.28(2928)$ \\
\hline 168 & $0.32(2938)$ & -- & -- & -- \\
\hline \multicolumn{5}{|c|}{ Region $3\left(1750-1700 \mathrm{~cm}^{-1}\right)$} \\
\hline \multicolumn{5}{|c|}{ Unaltered Lignin: 1.20 (1711) } \\
\hline 1 & -- & $0.80(1705)$ & $0.40(1709)$ & $0.31(1709)$ \\
\hline 8 & -- & $0.58(1711)$ & $0.47(1755)$ & $0.65(1765)$ \\
\hline 24 & $0.93(1709)$ & $0.61(1753)$ & $0.72(1769)$ & $0.87(1771)$ \\
\hline 48 & -- & $0.57(1755)$ & $0.80(1776)$ & $0.73(1776)$ \\
\hline 72 & $0.67(1709)$ & $0.59(1767)$ & $0.93(1776)$ & $0.97(1765)$ \\
\hline 168 & $0.52(1778)$ & -- & -- & -- \\
\hline \multicolumn{5}{|c|}{ Region 4 (1650 - $\left.1610 \mathrm{~cm}^{-1}\right)$} \\
\hline \multicolumn{5}{|c|}{ Unaltered Lignin: 1.32 (1607) } \\
\hline 1 & -- & $0.93(1611)$ & $0.45(1614)$ & $0.33(1611)$ \\
\hline 8 & -- & $0.62(1612)$ & $0.46(1626)$ & $0.62(1628)$ \\
\hline 24 & $1.01(1607)$ & $0.59(1620)$ & $0.66(1630)$ & $0.84(1632)$ \\
\hline 48 & -- & $0.55(1626)$ & $0.74(1632)$ & $0.69(1639)$ \\
\hline 72 & $0.71(1612)$ & $0.53(1630)$ & $0.87(1632)$ & $1.00(1632)$ \\
\hline 168 & $0.45(1630)$ & -- & -- & -- \\
\hline
\end{tabular}

and cellulose-containing materials (wood and bark) was maximized at low charring temperatures and long charring times. At a charring temperature of $250^{\circ} \mathrm{C}$, total acidity from cellulose continued to increase for times greater than 72 hours and reached 8.8 milliequivalents per gram. For a fixed charring time, total acidity from cellulose char decreased as charring temperature increased. Total acidity in lignin did not change substantially with low temperature charring $\left(250\right.$ to $\left.400^{\circ} \mathrm{C}\right)$.

The oxygen and carbon content of the chars were determined. Upon charring, both oxygen and carbon are lost from the starting material, but at unequal rates. Oxygen is lost more rapidly than carbon at the beginning of the charring process, but for longer durations of heating, carbon continues to be lost, while oxygen content remains fairly constant. For charring at a given temperature, this loss pattern results in the percentage carbon reaching a maximum in from 1 to 8 hours of charring and then decreasing with longer charring times, while percentage oxygen reaches a minimum during this period and then increases with charring time. Neither the percentage oxygen nor the carbon-to-oxygen atomic ratio correlate well with the observed increases in acid functional groups.

Diffuse reflectance mid-range infrared spectra were obtained for the chars. For all materials, charring caused a 
Table 11. The pseudo-absorbance of selected absorbance bands for diffuse reflectance infrared spectroscopy of pine wood and pine wood char.

[The absorbance is given in pseudo-absorbance units. The number in parenthesis is the wave number for the highest value of the absorbance band. ${ }^{\circ} \mathrm{C}$, degrees Celsius ; --, not determined]

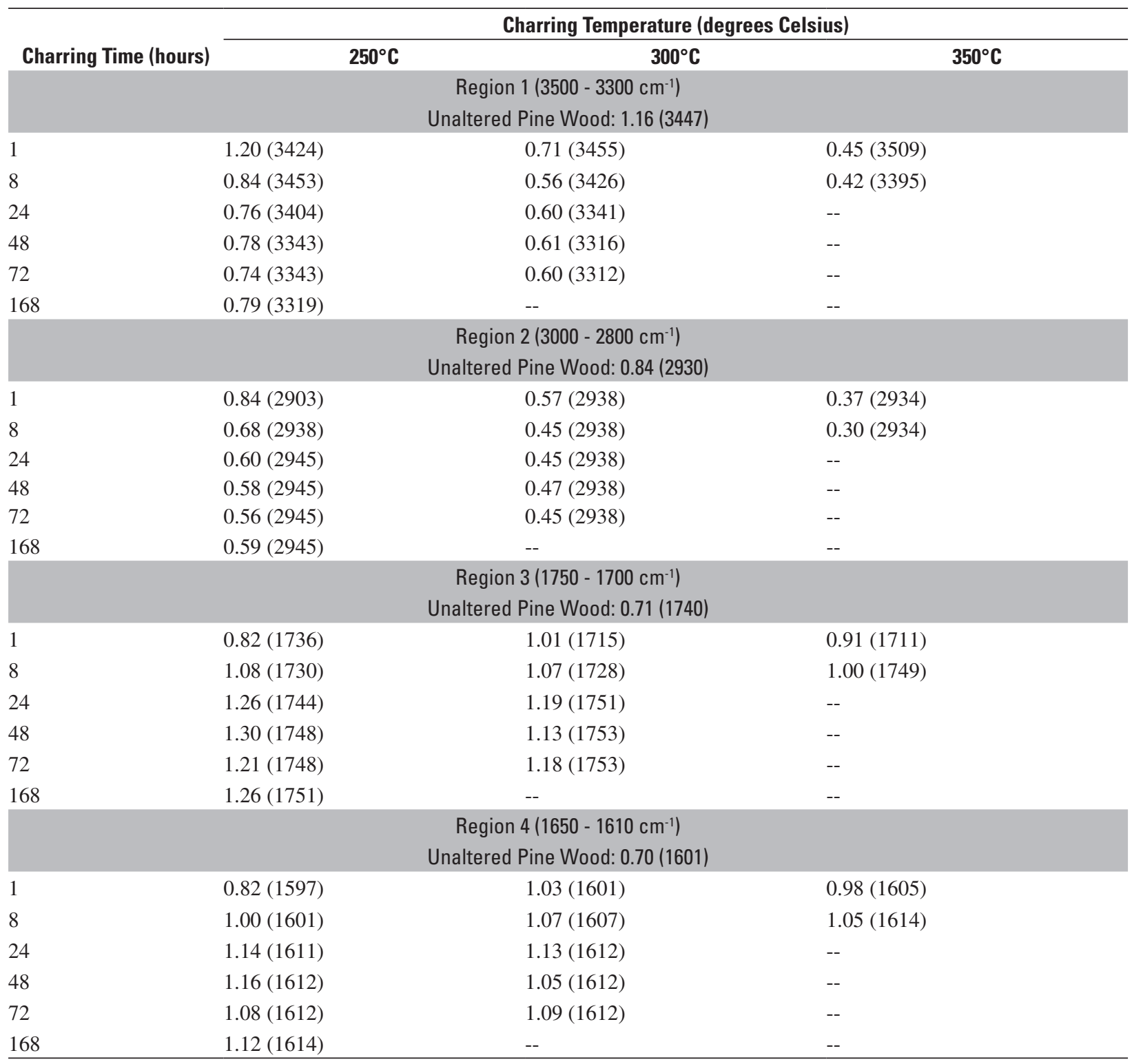


Table 12. The pseudo-absorbance of selected absorbance bands for diffuse reflectance infrared spectroscopy of pine bark and pine bark char.

[The absorbance is given in pseudo-absorbance units. The number in parenthesis is the wave number for the highest value of the absorbance band. ${ }^{\circ} \mathrm{C}$, degrees Celsius ; --, not determined]

\begin{tabular}{|c|c|c|c|}
\hline \multirow[b]{2}{*}{$\begin{array}{l}\text { Charring Time } \\
\text { (hours) }\end{array}$} & \multicolumn{3}{|c|}{ Charring Temperature (degrees Celsius) } \\
\hline & $250^{\circ} \mathrm{C}$ & $300^{\circ} \mathrm{C}$ & $350^{\circ} \mathrm{C}$ \\
\hline \multicolumn{4}{|c|}{ Region $1\left(3500-3300 \mathrm{~cm}^{-1}\right)$} \\
\hline \multicolumn{4}{|c|}{ Unaltered Pine Bark: 1.08 (3439) } \\
\hline 1 & $1.03(3437)$ & $0.70(3451)$ & $0.60(3451)$ \\
\hline 8 & $0.78(3443)$ & $0.64(3345)$ & $0.52(3455)$ \\
\hline 24 & $0.75(3426)$ & $0.63(3333)$ & $0.51(3339)$ \\
\hline 48 & -- & $0.68(3331)$ & $0.67(3327)$ \\
\hline 72 & $0.77(3329)$ & $0.71(3331)$ & -- \\
\hline 168 & $0.75(3329)$ & -- & -- \\
\hline \multicolumn{4}{|c|}{ Region $2\left(3000-2800 \mathrm{~cm}^{-1}\right)$} \\
\hline \multicolumn{4}{|c|}{ Unaltered Pine Bark: 0.84 (2926) } \\
\hline 1 & $0.81(2926)$ & $0.64(2930)$ & $0.54(2930)$ \\
\hline 8 & $0.68(2932)$ & $0.54(2934)$ & $0.41(2930)$ \\
\hline 24 & $0.61(2938)$ & $0.50(2934)$ & $0.39(2930)$ \\
\hline 48 & -- & $0.52(2934)$ & $0.52(2930)$ \\
\hline 72 & $0.60(2938)$ & $0.53(2934)$ & -- \\
\hline 168 & $0.59(2938)$ & -- & -- \\
\hline \multicolumn{4}{|c|}{ Region $3\left(1750-1700 \mathrm{~cm}^{-1}\right)$} \\
\hline \multicolumn{4}{|c|}{ Unaltered Pine Bark: 0.76 (1738) } \\
\hline 1 & $1.05(1713)$ & $0.99(1711)$ & $0.93(1713)$ \\
\hline 8 & $1.19(1732)$ & $1.06(1722)$ & $0.93(1713)$ \\
\hline 24 & $1.23(1738)$ & $1.08(1724)$ & $0.91(1713)$ \\
\hline 48 & -- & $1.20(1728)$ & $1.10(1713)$ \\
\hline 72 & $1.26(1744)$ & $1.14(1726)$ & -- \\
\hline 168 & $1.25(1746)$ & -- & -- \\
\hline \multicolumn{4}{|c|}{ Region $4\left(1650-1610 \mathrm{~cm}^{-1}\right)$} \\
\hline \multicolumn{4}{|c|}{ Unaltered Pine Bark: 1.05 (1614) } \\
\hline 1 & $1.19(1607)$ & $1.09(1603)$ & $1.04(1603)$ \\
\hline 8 & $1.20(1605)$ & $1.10(1603)$ & $1.10(1601)$ \\
\hline 24 & $1.19(1622)$ & $1.12(1601)$ & $1.08(1595)$ \\
\hline 48 & -- & $1.23(1601)$ & $1.22(1582)$ \\
\hline 72 & $1.16(1628)$ & $1.21(1595)$ & -- \\
\hline 168 & $1.16(1601)$ & -- & -- \\
\hline
\end{tabular}


reduction in absorbance in the broad band between 3500 reciprocal centimeters $\left(\mathrm{cm}^{-1}\right)$ and $3300 \mathrm{~cm}^{-1}$. This band is associated with oxygen-hydrogen stretching and the decrease in absorbance can be related to the overall loss of oxygen. Charring caused a reduction in absorbance in the bands between approximately 3000 and $2800 \mathrm{~cm}^{-1}$ for all materials. These bands are associated with aliphatic carbon-hydrogen stretching and the decrease in absorbance can be related to the overall loss of aliphatic carbons. For the charring of cellulose and cellulose containing materials (wood and bark), there were increases in absorbance of the sharp band between 1750 and $1700 \mathrm{~cm}^{-1}$, which is associated with carbonyl stretching and can be related to the creation of lactones and carboxylic acids. There are also increases in absorbance of the sharp band between 1650 and $1610 \mathrm{~cm}^{-1}$, which is associated with skeletal vibrations of fused ring aromatic structures and conjugated ketones, and can be related to the formation of fused aromatic rings and possibly hydrogen bonded quinones.

\section{References Cited}

Allan, G.G., 1971, Modification reactions, in Sarkanen, K.V., and Ludwig, C.H., eds., Lignins-Occurrence, formation, structure and reactions: New York, Wiley-Interscience, p. 511-573.

Boehm, H.P., Diehl, E., Heck, W., and Sappok, R., 1964, Surface oxides of carbon: Angewandte Chemie International Edition, v. 3, p. 669-677.

Brown, R.A., Kercher, A.K., Nguyen, T.H., Nagle, D.C., and Ball, W.P., 2006, Production and characterization of synthetic wood chars for use as surrogates for natural sorbents: Organic Geochemistry, v. 37, p. 321-333.

Chun, Yuan; Sheng, Guangyao; and Chiou, C.T., 2004a, Evaluation of current techniques for isolation of chars as natural adsorbents: Environmental Science and Technology, v. 38 , p. $4227-4232$.

Chun, Yuan; Sheng, Guangyao; Chiou, C.T., and Xing, Baoshan, 2004b, Compositions and sorptive properties of crop residue-derived chars: Environmental Science and Technology, v. 38, p. 4649-4655.

Colthup, N. B., Daly, L. H., and Wiberley, S. E., 1990, Introduction to infrared and raman spectroscopy: Boston, Academic Press, 547 p.

Contescu, A., Contescu, C., Putyera, K., and Schwarz, J.A., 1997, Surface acidity of carbons characterized by their continuous pK distribution and Boehm titration: Carbon, v. 35 , p. $83-94$.
Faix, Oskar, 1991, Classification of lignins from different botanical origins by FT-IR spectroscopy: Holzforschung, v. 45 (Suppl.), p, 21-27.

Glaser, B., Haumaier, L., Guggenberger, G., and Zech, W., 1998, Black carbon in soils-The use of benzenecarboxylic acids as specific markers: Organic Geochemistry, v. 29, p. 811-819.

Kramer, R. W., Kujawinski, E. B., and Hatcher, P. G., 2004, Identification of black carbon derived structures in a volcanic ash soil humic acid by Fourier transform ion cyclotron resonance mass spectrometry: Environmental Science and Technology, v. 38, p. 3387-3395.

Lehmann, Johannes; da Silva, J.P., Jr., Steiner, Christoph; Nehls, Thomas; Zech, Wolfgang; and Glaser, Bruno, 2003, Nutrient availability and leaching in an archaeological Anthrosol and Ferralsol of the Central Amazon basinFertilizer, manure and charcoal amendments: Plant and Soil, v. 249 , p. $343-357$.

Liang, B., Lehmann, J., Solomon, D., Kinyangi, J., Grossman, J., O’Neill, B, Skjemstad, J.O., Thies, J., Luixao, F.J., Petersen, J., and Neves, E.G., 2006, Black carbon increases cation exchange capacity in soils: Soil Science Society of America Journal, v. 70, p. 1719-1730.

Lopez-Ramon, M.V., Stoeckli, F., Moreno-Castilla, C., and Carrasco-Marin, F., 1999, On the characterization of acidic and basic surface sites on carbons by various techniques: Carbon, v. 37, p. 1215-1221.

McGrath, T.E., Chan, W.G., and Hajaligol, M.R., 2003, Low temperature mechanism for the formation of polycyclic aromatic hydrocarbons from pyrolysis of cellulose: Journal of Analytical and Applied Pyrolysis, v. 66, p. 51-70.

Nimlos, M.R., Blanksby, S.J., Ellison, G.B. and Evans, R.J., 2003, Enhancement of 1,2-dehydration of alcohols by alkali cations and protons-A model for dehydration of carbohydrates: Journal of Analytical and Applied Pyrolysis, v. 66, p. 3-27.

Patrick, J.W., 1995, Porosity in carbons-Characteristics and applications: New York, Halstad Press, 331p.

Pettersen, R.C., 1984, The chemical composition of wood, in The chemistry of solid wood, Rowell, R. M., ed., Advances in Chemistry Series 20: Washington, D.C., American Chemical Society.

Rutherford, D.W., Wershaw, R.L., and Cox, L.G., 2004, Changes in composition and porosity occurring during the thermal degradation of wood and wood components: U.S. Geological Survey Scientific Investigations Report 2004-5292, 79 p. 
Sahai, Nita, and Sverjensky, D.A., 1997, Evaluation of internally consistent parameters for the triple-layer model by the systematic analysis of oxide surface titration data: Geochimica et Cosmochemica Acta, v. 61, p. 2801-2826.

Sahai, Nita, 2002, Is silica really an anomalous oxide? Surface acidity and aqueous hydroxysis revisted: Environmental Science \& Technology, v. 36, p. 445-452.

Salame, I.I., and Bandosz, T.J., 2001, Surface chemistry of activated carbons-Combining the results of temperatureprogrammed desorption, Boehm, and potentiometric titrations: Journal of Colloid and Interface Science, v. 240, p. 252-258.

Sanders, E.B., Goldsmith, A.I, and Seeman, J.I., 2003, A model that distinguishes the pyrolysis of D-glucose, D-fructose, and sucrose from that of cellulose-Application to the understanding of cigarette smoke formation: Journal of Analytical and Applied Pyrolysis, v. 66, p. 29-50.

Shafizadeh, Fred, 1982, Introduction to pyrolysis of biomass: Journal of Analytical and Applied Pyrolysis, v. 3, p. 283-305.

Shafizadeh, Fred, 1984, The chemistry of pyrolysis and combustion, in The chemistry of solid wood, Rowell, Roger, ed., Advances in Chemistry Series 207: Washington D.C., American Chemical Society, p. 489-529.

Sharma, R.K., and Hajaligol, M.R., 2003, Effect of pyrolysis conditions on the formation of polycylic aromatic hydrocarbons (PAHs) from polyphenolic compounds: Journal of Analytical and Applied Pyrolysis, v. 66, p. 123-144.
Sharma, R.K., Chan, W.G., Seeman, J.I., and Hajaligol, M.R., 2003, Formation of low molecular weight heterocycles and polycyclic aromatic compounds (PACs) in the pyrolysis of $\alpha$-amino acids: Journal of Analytical and Applied Pyrolysis, v. 66, p. $97-121$.

Simoneit, B.R.T., 2002, Biomass burning-A review of organic tracers for smoke from incomplete combustion: Applied Geochemistry, v. 17, p. 129-162.

Skjemstad, J.O., Reicosky, D.C., Wilts, A.R., and McGowan, J.A., 2002, Charcoal carbon in U.S. agricultural soils: Soil Science Society of America Journal, v. 66, p. 1249-1255.

Sposito, Garrison; Skipper, N.T., Sutton, Rebecca; Park, Sungho; Soper, A.K., and Greathouse, J.A., 1999, Surface geochemistry of the clay minerals: Proceedings of the National Academy of Science USA, v. 96, p. 3358-3364.

Wershaw, R.L., Leenheer, J.R., Sperline, R.P., Song, Y., Noll, L.A., Melvin, R.L., and Rigatti, G.P., 1995, Mechanism of formation of humus coatings on mineral surfaces 1 . Evidence for multidentate binding of organic acids from compost leachate on alumina: Colloids and Surfaces Part A, v. 96. p. 93-104.

Zhou, Q, Maurice, P.A., and Cabaniss, S.E., 2001, Size fractionation upon adsorption of fulvic acid on goethiteEquilibrium and kinetic studies: Geochimica et Cosmochemica Acta, v. 65, p. 803-812. 


\section{Appendix 1. Results of Boehm Titrations}


Table 1-1. Results of Boehm titrations for cellulose and cellulose chars.

[The table shows the average base neutralized in milliequivalents per gram of sample (meq/g) for the replicates of each treatment (equilibration with $\mathrm{NaOH}, \mathrm{NaHCO}_{3}$, and $\mathrm{Na}_{2} \mathrm{CO}_{3}$ ). The number in parentheses is the standard error of the mean.]

\begin{tabular}{|c|c|c|c|c|}
\hline $\begin{array}{l}\text { Charring } \\
\text { conditions }\end{array}$ & $\begin{array}{c}\mathrm{meq} / \mathrm{g} \text { of } \mathrm{NaOH} \\
\text { Neutralized }\end{array}$ & $\begin{array}{c}\mathrm{meq} / \mathrm{g} \text { of } \mathrm{NaHCO}_{3} \\
\text { Neutralized }\end{array}$ & $\begin{array}{c}\mathrm{meq} / \mathrm{g} \text { of } \mathrm{Na}_{2} \mathrm{CO}_{3} \\
\text { Neutralized }\end{array}$ & $\begin{array}{l}\text { Number of } \\
\text { replicates }\end{array}$ \\
\hline $\begin{array}{l}\text { Unaltered } \\
\text { Cellulose }\end{array}$ & $0.09(0.005)$ & 0.0 & $0.007(0.005)$ & 2 \\
\hline \multicolumn{5}{|c|}{ Cellulose Char } \\
\hline \multicolumn{5}{|c|}{$200^{\circ} \mathrm{C}$} \\
\hline 72 hours & $0.66(0.015)$ & $0.15(0.010)$ & $0.51(0.115)$ & 2 \\
\hline 168 hours & $1.96(0.005)$ & $0.41(0.010)$ & $1.02(0.060)$ & 2 \\
\hline \multicolumn{5}{|c|}{$250^{\circ} \mathrm{C}$} \\
\hline 8 hours & $3.93(0.160)$ & $0.82(0.010)$ & $1.96(0.075)$ & 2 \\
\hline 24 hours & $6.59(0.025)$ & $2.06(0.005)$ & $4.22(0.040)$ & 2 \\
\hline 72 hours & $8.72(0.095)$ & $3.52(0.020)$ & $6.12(0.040)$ & 2 \\
\hline 168 hours & $8.83(0.140)$ & $3.84(0.080)$ & $6.38(0.075)$ & 2 \\
\hline \multicolumn{5}{|c|}{$300^{\circ} \mathrm{C}$} \\
\hline 8 hours & $4.04(0.250)$ & $0.98(0.090)$ & $2.70(0.115)$ & 2 \\
\hline 24 hours & $6.21(0.130)$ & $1.81(0.015)$ & $4.17(0.040)$ & 2 \\
\hline 48 hours & $7.16(0.200)$ & $2.35(0.055)$ & $5.00(0.080)$ & 2 \\
\hline 72 hours & $7.38(0.070)$ & $2.55(0.004)$ & $4.99(0.050)$ & 2 \\
\hline \multicolumn{5}{|c|}{$350^{\circ} \mathrm{C}$} \\
\hline 8 hours & $3.04(0.420)$ & $0.88(0.045)$ & $1.90(0.010)$ & 2 \\
\hline 24 hours & $5.12(0.028)$ & $1.57(0.031)$ & $3.25(0.023)$ & 3 \\
\hline 48 hours & $5.02(0.025)$ & $1.58(0.010)$ & $3.42(0.105)$ & 2 \\
\hline 72 hours & $5.62(0.064)$ & $1.67(0.082)$ & $3.78(0.090)$ & 3 \\
\hline \multicolumn{5}{|c|}{$400^{\circ} \mathrm{C}$} \\
\hline 8 hours & $2.35(0.020)$ & $0.38(0.270)$ & $1.63(0.030)$ & 2 \\
\hline 24 hours & $3.25(0.045)$ & $0.91(0.015)$ & $2.08(0.005)$ & 2 \\
\hline 48 hours & $4.21(0.120)$ & $1.31(0.010)$ & $2.63(0.035)$ & 2 \\
\hline 72 hours & $4.04(0.060)$ & $1.21(0.065)$ & $2.60(0.030)$ & 2 \\
\hline
\end{tabular}


Table 1-2. Results of Boehm titrations for lignin and lignin chars.

[The table shows the average base neutralized in milliequivalents per gram of sample (meq/g) for the replicates of each treatment (equilibration with $\mathrm{NaOH}, \mathrm{NaHCO}_{3}$, and $\mathrm{Na}_{2} \mathrm{CO}_{3}$ ). The number in parentheses is the standard error of the mean.]

\begin{tabular}{|c|c|c|c|c|}
\hline $\begin{array}{l}\text { Charring } \\
\text { conditions }\end{array}$ & $\begin{array}{c}\text { meq/g of } \\
\text { NaOH } \\
\text { Neutralized }\end{array}$ & $\begin{array}{c}\mathrm{meq} / \mathrm{g} \text { of } \\
\mathrm{NaHCO}_{3} \\
\text { Neutralized }\end{array}$ & $\begin{array}{c}\mathrm{meq} / \mathrm{g} \text { of } \\
\mathrm{Na}_{2} \mathrm{CO}_{3} \\
\text { Neutralized }\end{array}$ & $\begin{array}{c}\text { Number } \\
\text { of } \\
\text { replicates }\end{array}$ \\
\hline $\begin{array}{l}\text { Unaltered } \\
\text { Lignin }\end{array}$ & $1.23(0.060)$ & $0.15(0.005)$ & $0.56(0.175)$ & 2 \\
\hline \multicolumn{5}{|c|}{ Lignin Char } \\
\hline \multicolumn{5}{|c|}{$250^{\circ} \mathrm{C}$} \\
\hline 72 hours & $0.97(0.010)$ & $0.18(0.025)$ & $0.37(0.030)$ & 2 \\
\hline 168 hours & $1.45(0.185)$ & $0.49(0.025)$ & $0.86(0.105)$ & 2 \\
\hline \multicolumn{5}{|c|}{$300^{\circ} \mathrm{C}$} \\
\hline 24 hours & $1.18(0.620)$ & $0.17(0.055)$ & $0.36(0.035)$ & 2 \\
\hline 48 hours & $1.51(0.020)$ & $0.65(0.000)$ & $1.31(0.080)$ & 2 \\
\hline 72 hours & $2.55(0.195)$ & $1.18(0.060)$ & $2.03(0.045)$ & 2 \\
\hline \multicolumn{5}{|c|}{$350^{\circ} \mathrm{C}$} \\
\hline 24 hours & $1.23(0.025)$ & $0.62(0.015)$ & $0.94(0.025)$ & 2 \\
\hline 48 hours & $3.52(0.142)$ & $1.61(0.046)$ & $2.72(0.054)$ & 3 \\
\hline 72 hours & $2.58(0.155)$ & $1.27(0.030)$ & $2.30(0.195)$ & 2 \\
\hline \multicolumn{5}{|c|}{$400^{\circ} \mathrm{C}$} \\
\hline 24 hours & $2.55(0.000)$ & $0.82(0.055)$ & $1.47(0.000)$ & 2 \\
\hline 48 hours & $2.94(0.545)$ & $1.23(0.020)$ & $2.36(0.065)$ & 2 \\
\hline 72 hours & $3.47(0.100)$ & $0.97(0.065)$ & $2.16(0.110$ & 2 \\
\hline \multicolumn{5}{|c|}{$450^{\circ} \mathrm{C}$} \\
\hline 24 hours & $2.24(0.005)$ & $0.66(0.035)$ & $1.44(0.040)$ & 2 \\
\hline
\end{tabular}


Table 1-3. Results of Boehm titrations for pine wood and pine wood chars.

[The table shows the average base neutralized in milliequivalents per gram of sample (meq/g) for the replicates of each treatment (equilibration with $\mathrm{NaOH}, \mathrm{NaHCO}_{3}$, and $\mathrm{Na}_{2} \mathrm{CO}_{3}$ ). The number in parentheses is the standard error of the mean.]

\begin{tabular}{|c|c|c|c|c|}
\hline $\begin{array}{l}\text { Charring } \\
\text { conditions }\end{array}$ & $\begin{array}{c}\mathrm{meq} / \mathrm{g} \text { of } \mathrm{NaOH} \\
\text { Neutralized }\end{array}$ & $\begin{array}{c}\mathrm{meq} / \mathrm{g} \text { of } \mathrm{NaHCO}_{3} \\
\text { Neutralized }\end{array}$ & $\begin{array}{c}\mathrm{meq} / \mathrm{g} \text { of } \mathrm{Na}_{2} \mathrm{CO}_{3} \\
\text { Neutralized }\end{array}$ & $\begin{array}{l}\text { Number of } \\
\text { replicates }\end{array}$ \\
\hline $\begin{array}{l}\text { Unaltered } \\
\text { Pine Wood }\end{array}$ & $0.89(0.035)$ & $0.05(0.005)$ & $0.17(0.010)$ & 2 \\
\hline \multicolumn{5}{|c|}{ Pine Wood Char } \\
\hline \multicolumn{5}{|c|}{$250^{\circ} \mathrm{C}$} \\
\hline 8 hours & $2.93(0.011)$ & $0.32(0.018)$ & $0.52(0.111)$ & 2 \\
\hline 24 hours & $5.40(0.030)$ & $1.09(0.050)$ & $3.11(0.070)$ & 2 \\
\hline 72 hours & $7.10(0.170)$ & $2.16(0.015)$ & $4.77(0.005)$ & 2 \\
\hline 168 hours & $7.83(0.035)$ & $2.80(0.055)$ & $5.37(0.010)$ & 2 \\
\hline \multicolumn{5}{|c|}{$300^{\circ} \mathrm{C}$} \\
\hline 1 hour & $2.47(0.428)$ & $0.15(0.050)$ & $0.85(0.081)$ & 2 \\
\hline 8 hours & $4.39(0.140)$ & $1.02(0.080)$ & $2.62(0.070)$ & 2 \\
\hline 24 hours & $5.49(0.045)$ & $1.48(0.062)$ & $3.54(0.021)$ & 2 \\
\hline 48 hours & $6.09(0.005)$ & $1.68(0.031)$ & $3.83(0.080)$ & 2 \\
\hline 72 hours & $5.88(0.055)$ & $1.83(0.085)$ & $3.80(0.180)$ & 2 \\
\hline \multicolumn{5}{|c|}{$350^{\circ} \mathrm{C}$} \\
\hline 8 hours & $2.38(0.010)$ & $0.57(0.135)$ & $1.46(0.085)$ & 2 \\
\hline \multicolumn{5}{|c|}{$400^{\circ} \mathrm{C}$} \\
\hline 8 hours & $1.35(0.155)$ & $0.18(0.015)$ & $0.67(0.105)$ & 2 \\
\hline
\end{tabular}

Table 1-4. Results of Boehm titrations for pine bark and pine bark chars.

[The table shows the average base neutralized in milliequivalents per gram of sample (meq/g) for the replicates of each treatment (equilibration with $\mathrm{NaOH}, \mathrm{NaHCO}_{3}$, and $\mathrm{Na}_{2} \mathrm{CO}_{3}$ ). The number in parentheses is the standard error of the mean.]

\begin{tabular}{|c|c|c|c|c|}
\hline $\begin{array}{l}\text { Charring } \\
\text { conditions }\end{array}$ & $\begin{array}{c}\mathrm{meq} / \mathrm{g} \text { of } \mathrm{NaOH} \\
\text { Neutralized }\end{array}$ & $\begin{array}{c}\text { meq/g of } \mathrm{NaHCO}_{3} \\
\text { Neutralized }\end{array}$ & $\begin{array}{c}\mathrm{meq} / \mathrm{g} \text { of } \mathrm{Na}_{2} \mathrm{CO}_{3} \\
\text { Neutralized }\end{array}$ & $\begin{array}{l}\text { Number of } \\
\text { replicates }\end{array}$ \\
\hline $\begin{array}{l}\text { Unaltered } \\
\text { Pine Bark }\end{array}$ & $1.57(0.180)$ & $0.18(0.025)$ & $0.85(0.035)$ & 2 \\
\hline \multicolumn{5}{|c|}{ Pine Bark Char } \\
\hline \multicolumn{5}{|c|}{$250^{\circ} \mathrm{C}$} \\
\hline 8 hours & $2.70(0.215)$ & $0.24(0.015)$ & $0.74(0.255)$ & 2 \\
\hline 24 hours & $3.97(0.120)$ & $0.63(0.035)$ & $2.00(0.030)$ & 2 \\
\hline 72 hours & $5.47(0.450)$ & $1.29(0.155)$ & $2.98(0.200)$ & 2 \\
\hline 168 hours & $5.96(0.245)$ & $1.60(0.020)$ & $3.63(0.015)$ & 2 \\
\hline \multicolumn{5}{|c|}{$300^{\circ} \mathrm{C}$} \\
\hline 1 hour & $2.24(0.420)$ & $0.09(0.005)$ & $0.92(0.405)$ & 2 \\
\hline 8 hours & $2.38(0.165)$ & $0.27(0.030)$ & $0.92(0.095)$ & 2 \\
\hline 24 hours & $2.86(0.140)$ & $0.45(0.010)$ & $1.36(0.035)$ & 2 \\
\hline 48 hours & $3.62(0.050)$ & $0.45(0.030)$ & $1.60(0.115)$ & 2 \\
\hline 72 hours & $3.52(0.040)$ & $0.25(0.045)$ & $1.47(0.060)$ & 2 \\
\hline \multicolumn{5}{|c|}{$350^{\circ} \mathrm{C}$} \\
\hline 8 hours & $1.59(0.530)$ & $0.00(0)$ & $0.41(0.075)$ & 2 \\
\hline \multicolumn{5}{|c|}{$400^{\circ} \mathrm{C}$} \\
\hline 8 hours & $0.47(0.055)$ & $0.00(0)$ & $0.24(0.085$ & 2 \\
\hline
\end{tabular}




\section{Appendix 2. Diffuse Reflectance Mid-Range Infrared Spectra}

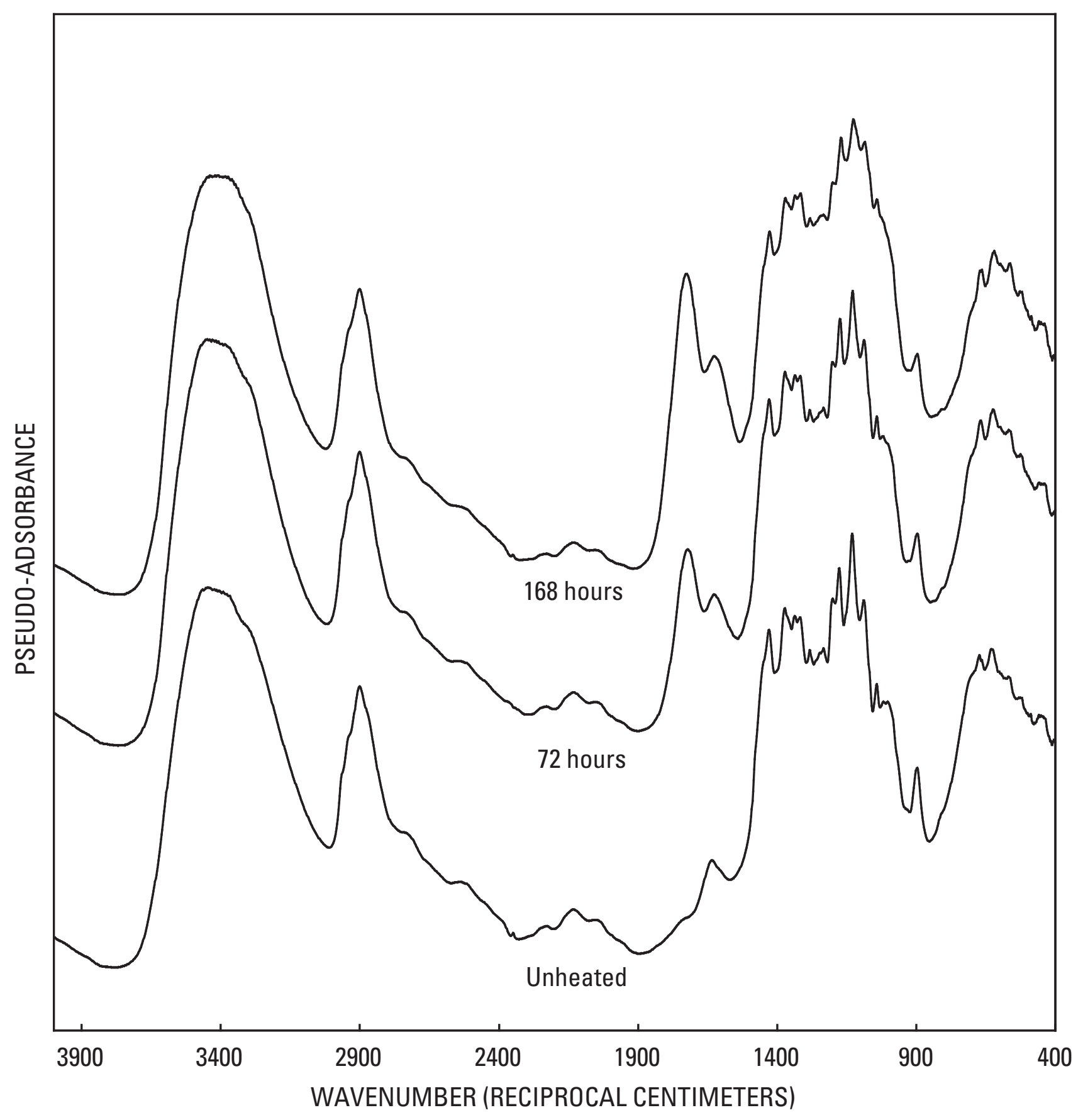

Figure 2-1. Diffuse reflectance mid-range infrared spectra of cellulose heated at $200^{\circ} \mathrm{C}$ for various times. 


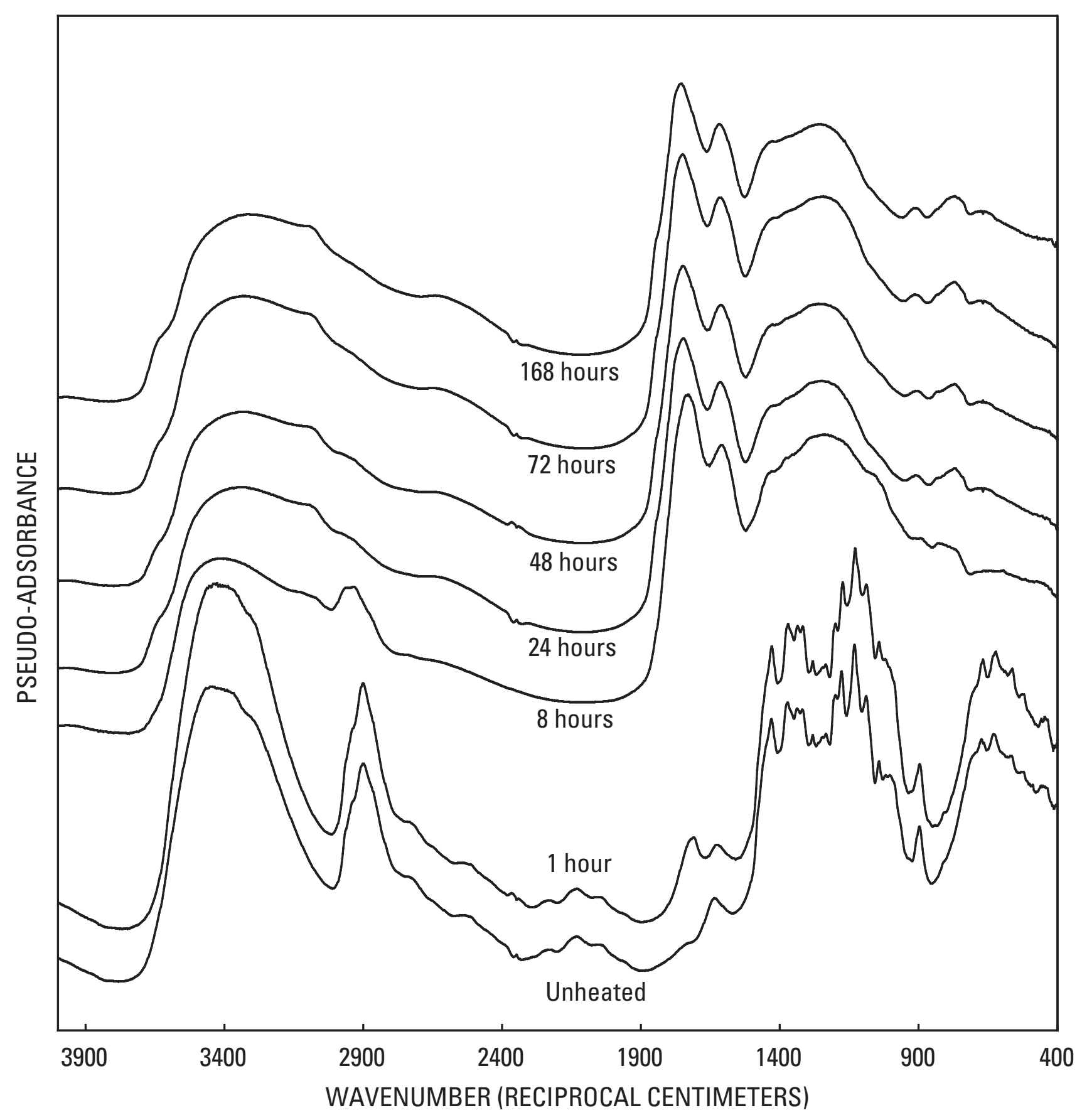

Figure 2-2. Diffuse reflectance mid-range infrared spectra of cellulose heated at $250^{\circ} \mathrm{C}$ for various times. 


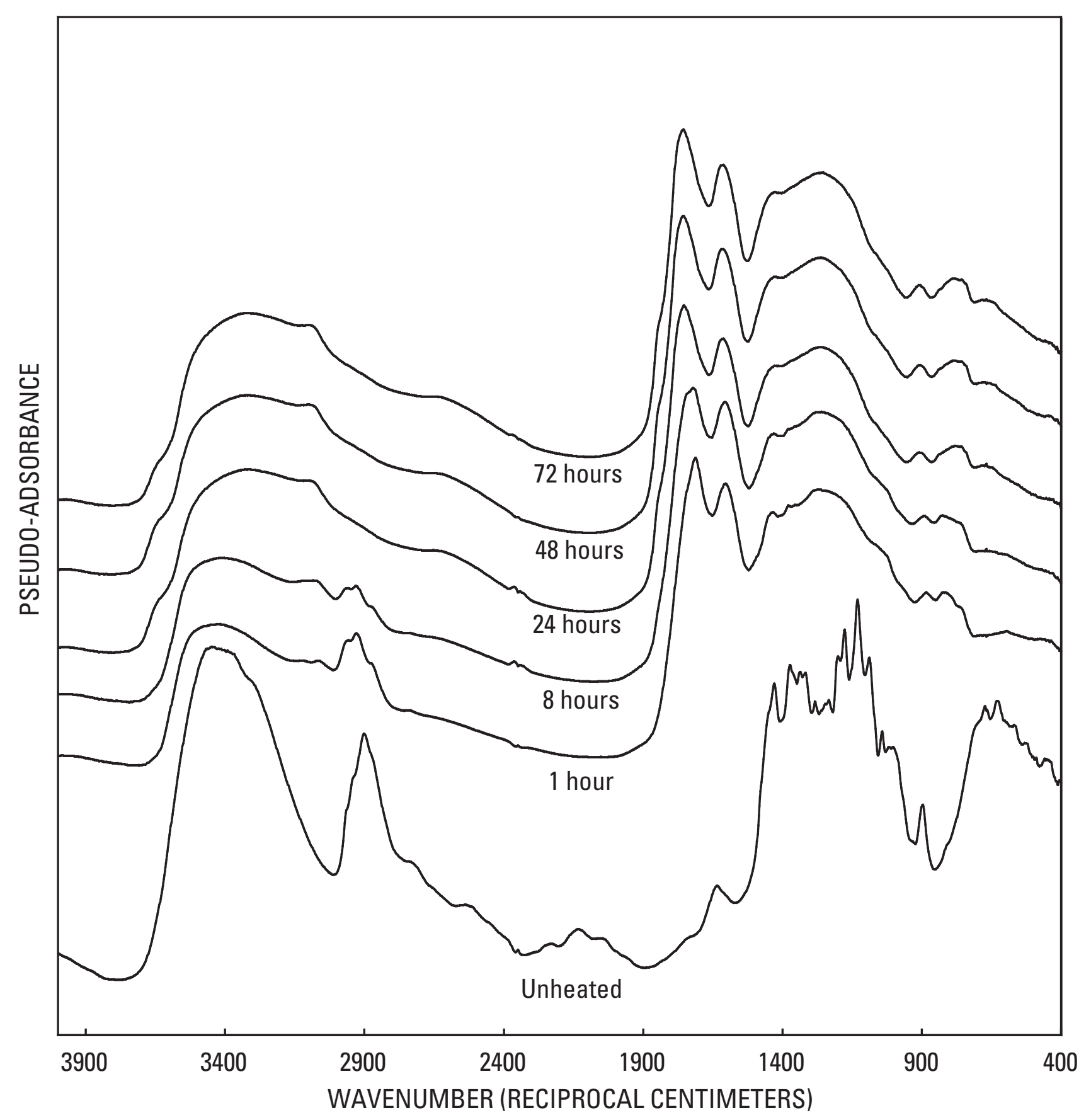

Figure 2-3. Diffuse reflectance mid-range infrared spectra of cellulose heated at $300^{\circ} \mathrm{C}$ for various times. 


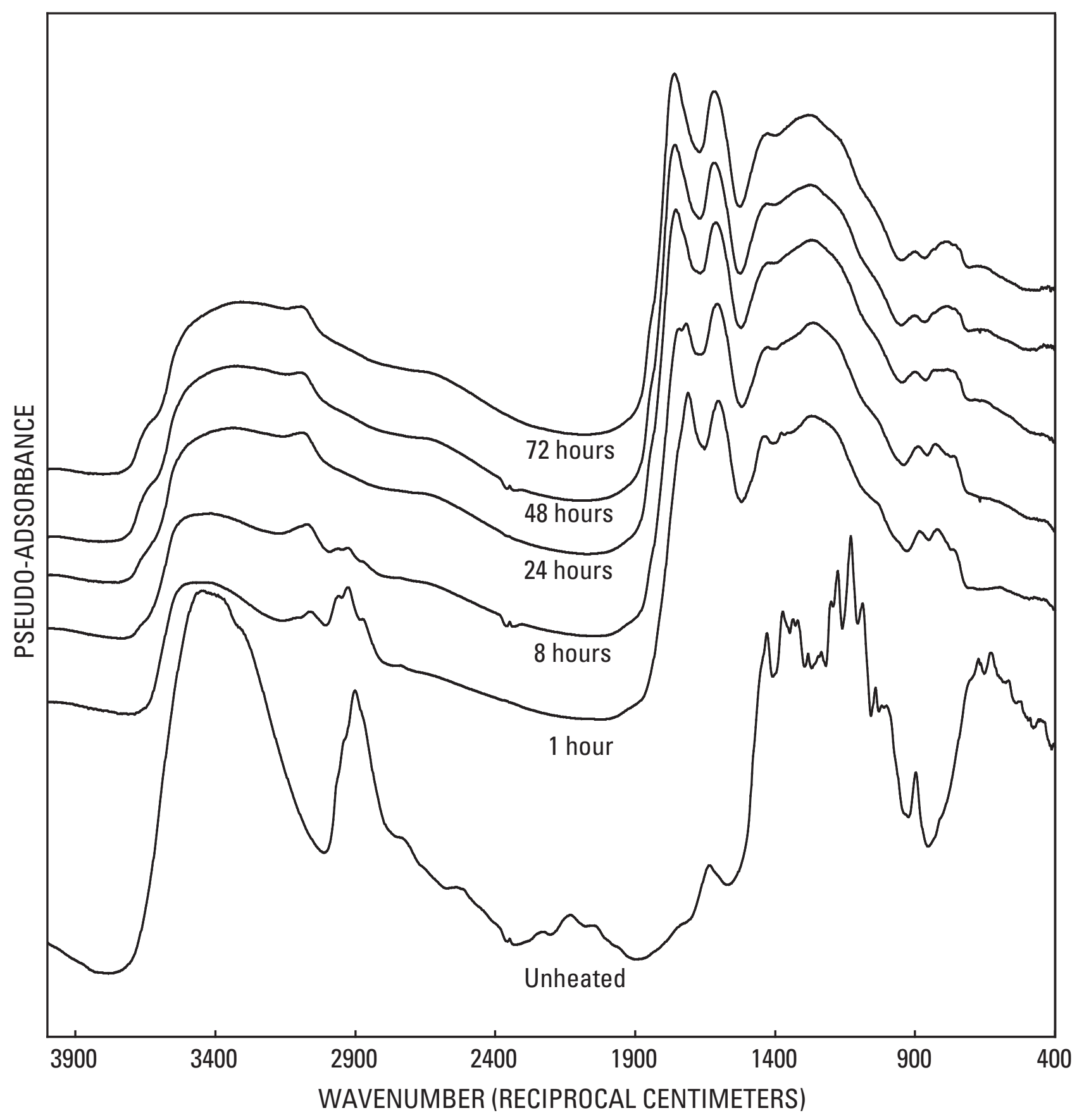

Figure 2-4. Diffuse reflectance mid-range infrared spectra of cellulose heated at $350^{\circ} \mathrm{C}$ for various times. 


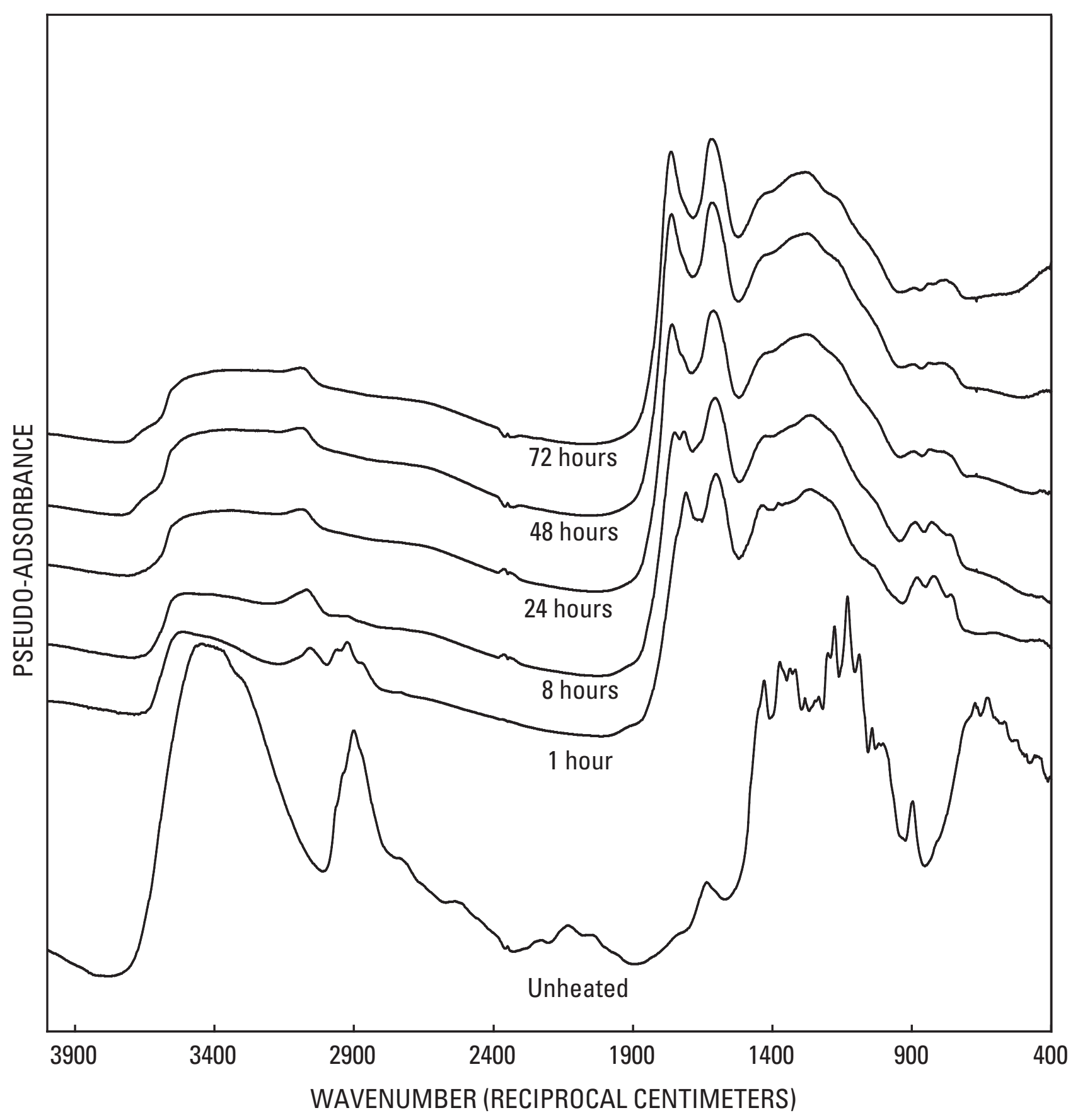

Figure 2-5. Diffuse reflectance mid-range infrared spectra of cellulose heated at $400^{\circ} \mathrm{C}$ for various times. 


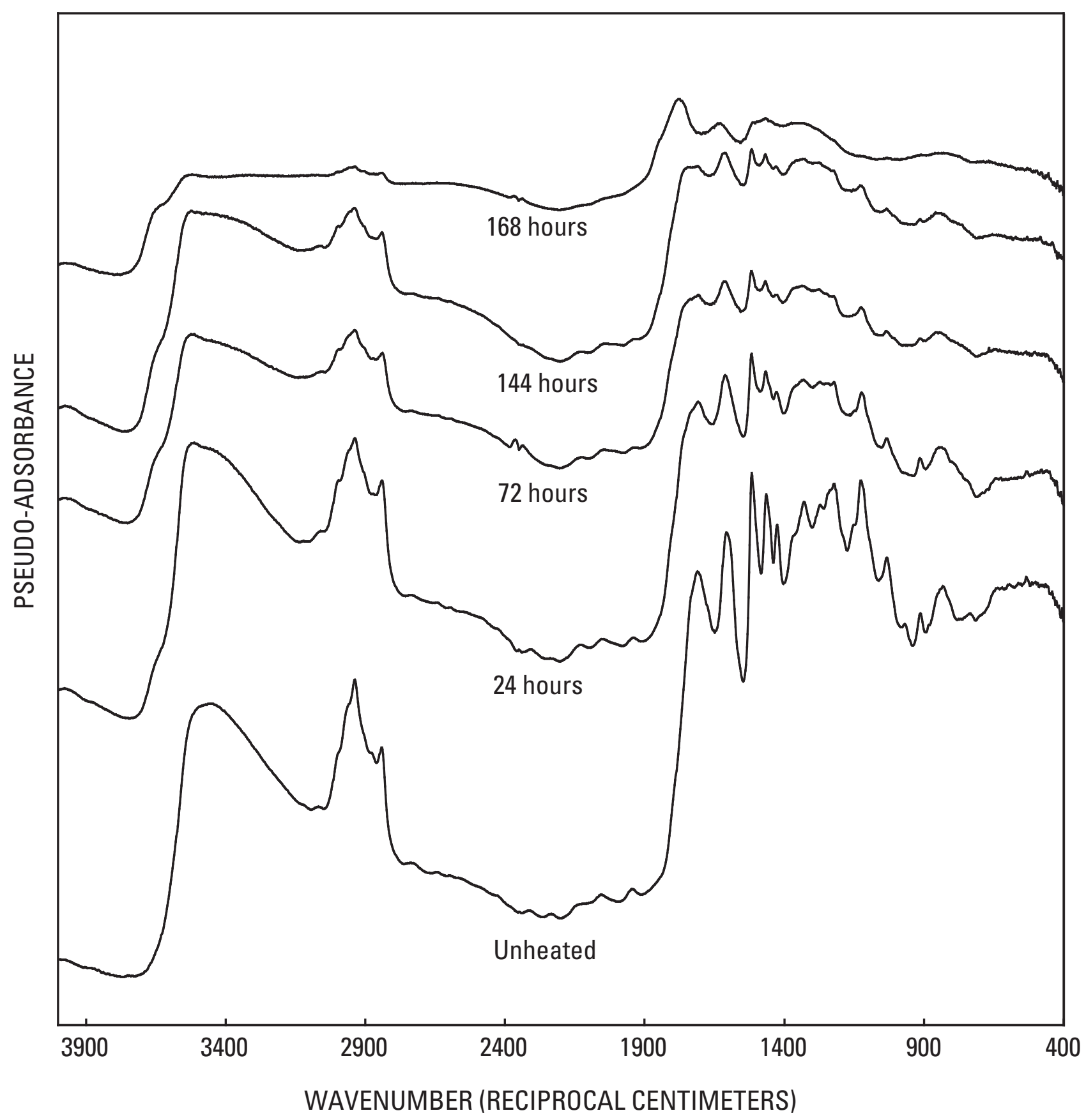

Figure 2-6. Diffuse reflectance mid-range infrared spectra of lignin heated at $250^{\circ} \mathrm{C}$ for various times. 


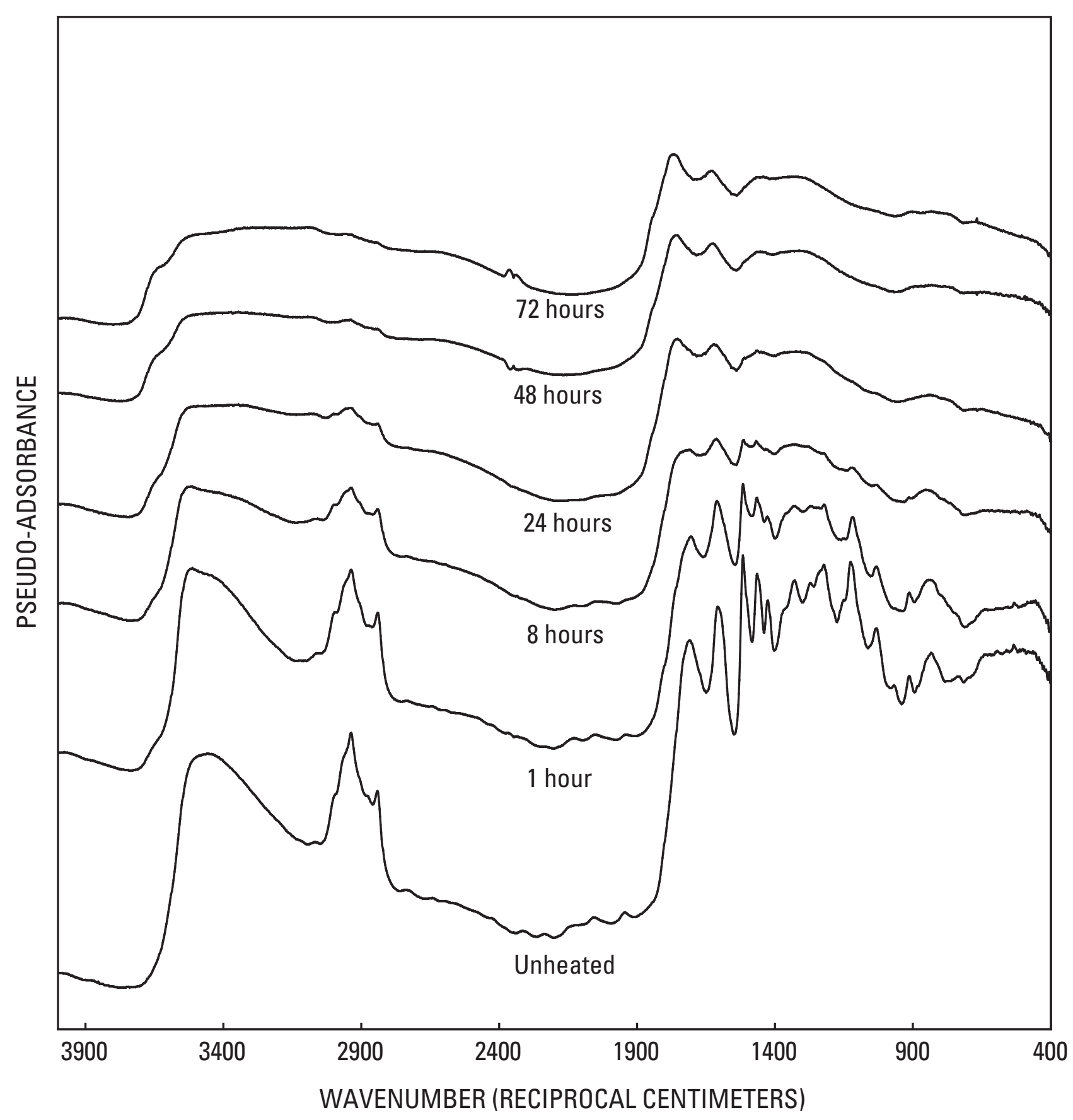

Figure 2-7. Diffuse reflectance mid-range infrared spectra of lignin heated at $300^{\circ} \mathrm{C}$ for various times. 


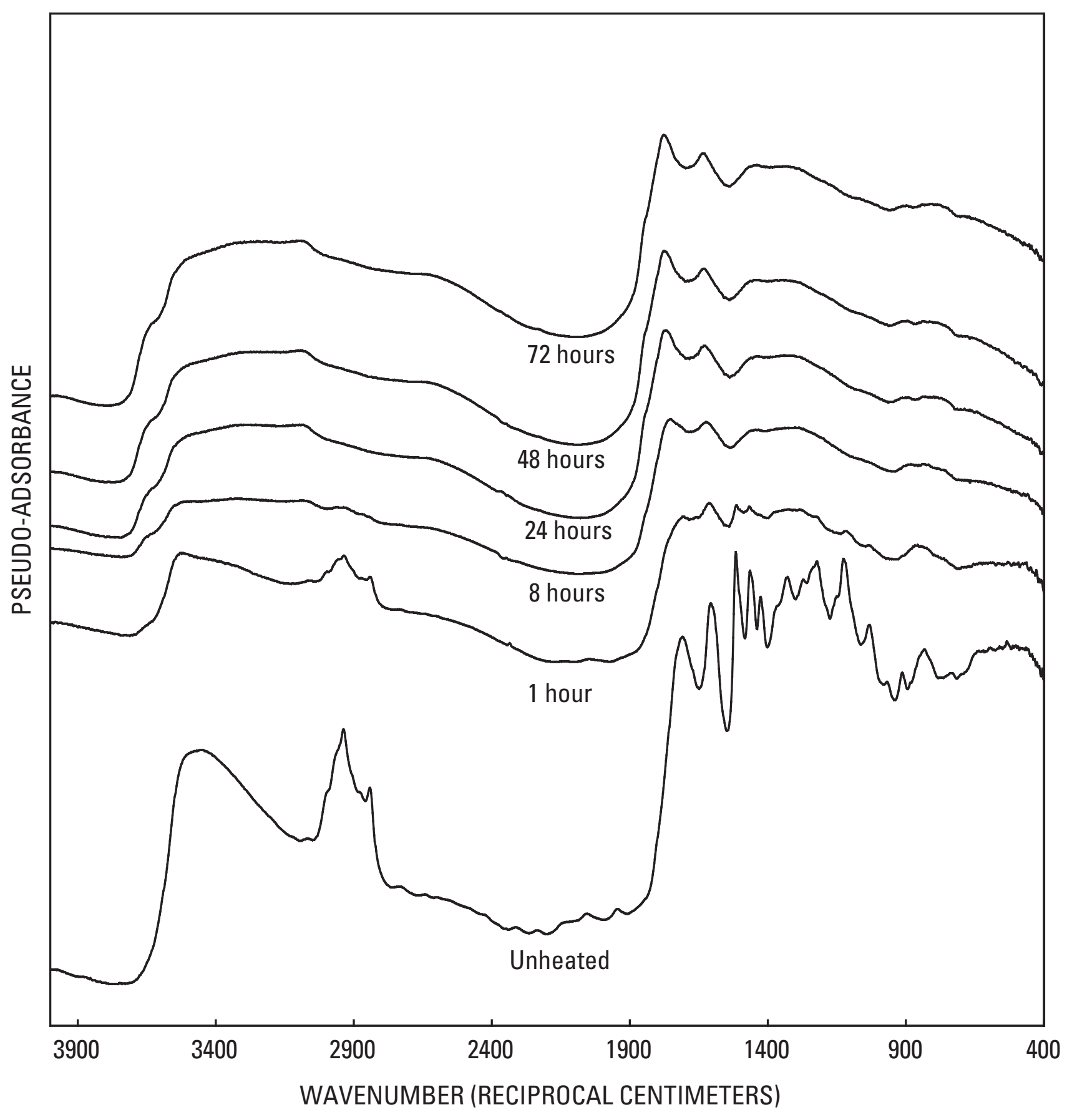

Figure 2-8. Diffuse reflectance mid-range infrared spectra of lignin heated at $350^{\circ} \mathrm{C}$ for various times. 


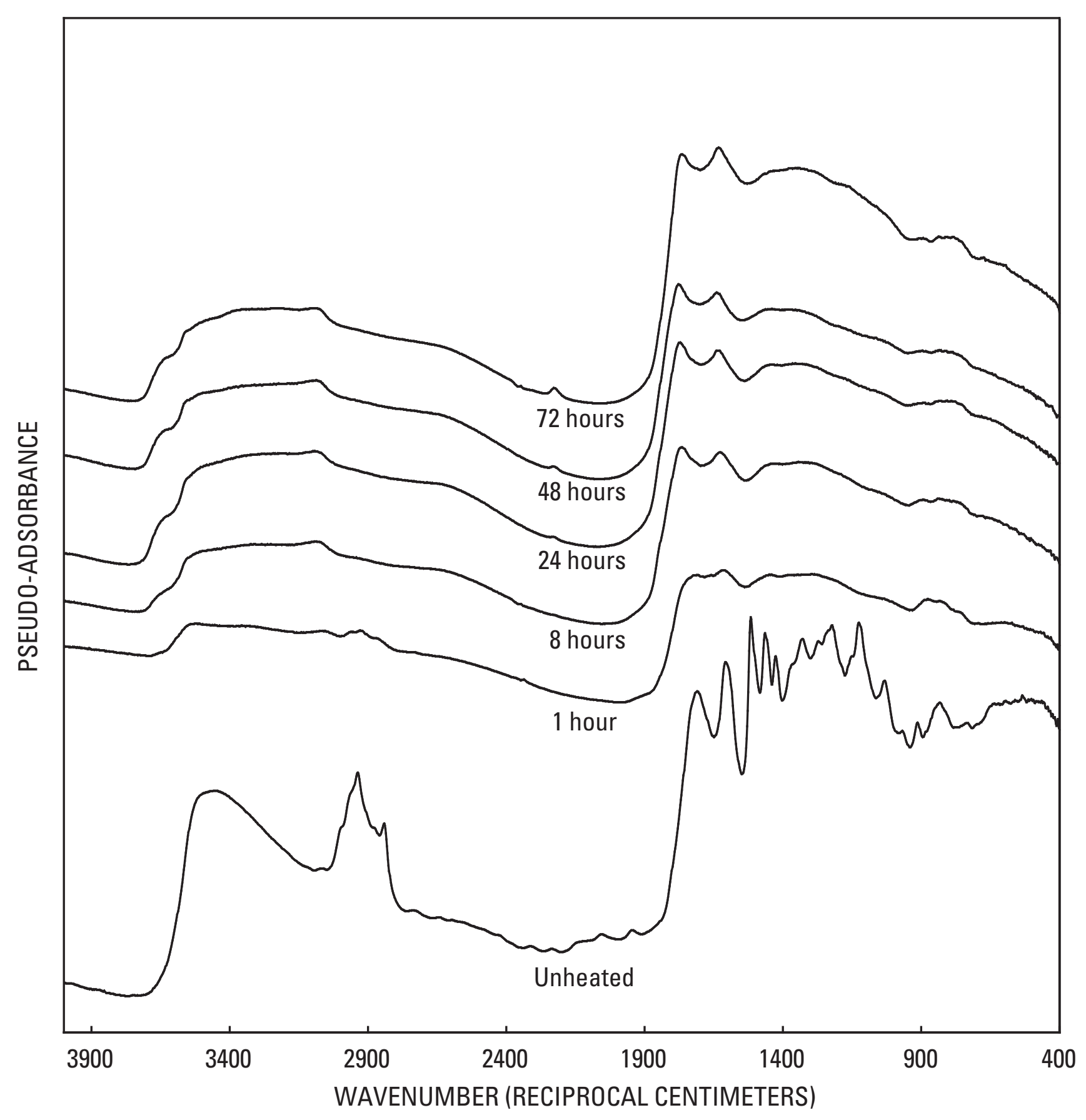

Figure 2-9. Diffuse reflectance mid-range infrared spectra of lignin heated at $400^{\circ} \mathrm{C}$ for various times. 


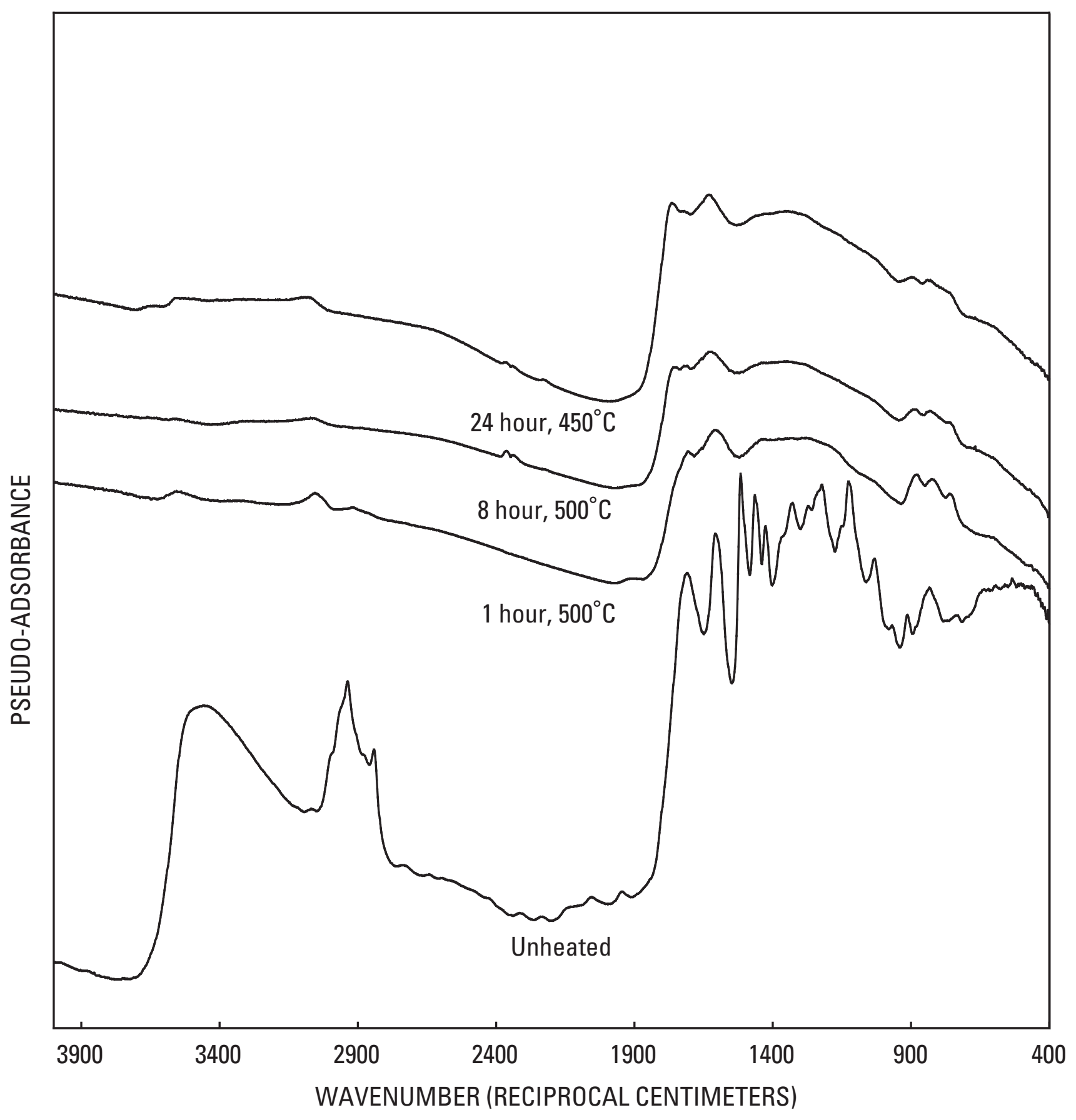

Figure 2-10. Diffuse reflectance mid-range infrared spectra of lignin heated at $450^{\circ} \mathrm{C}$ and $500^{\circ} \mathrm{C}$ for various times. 


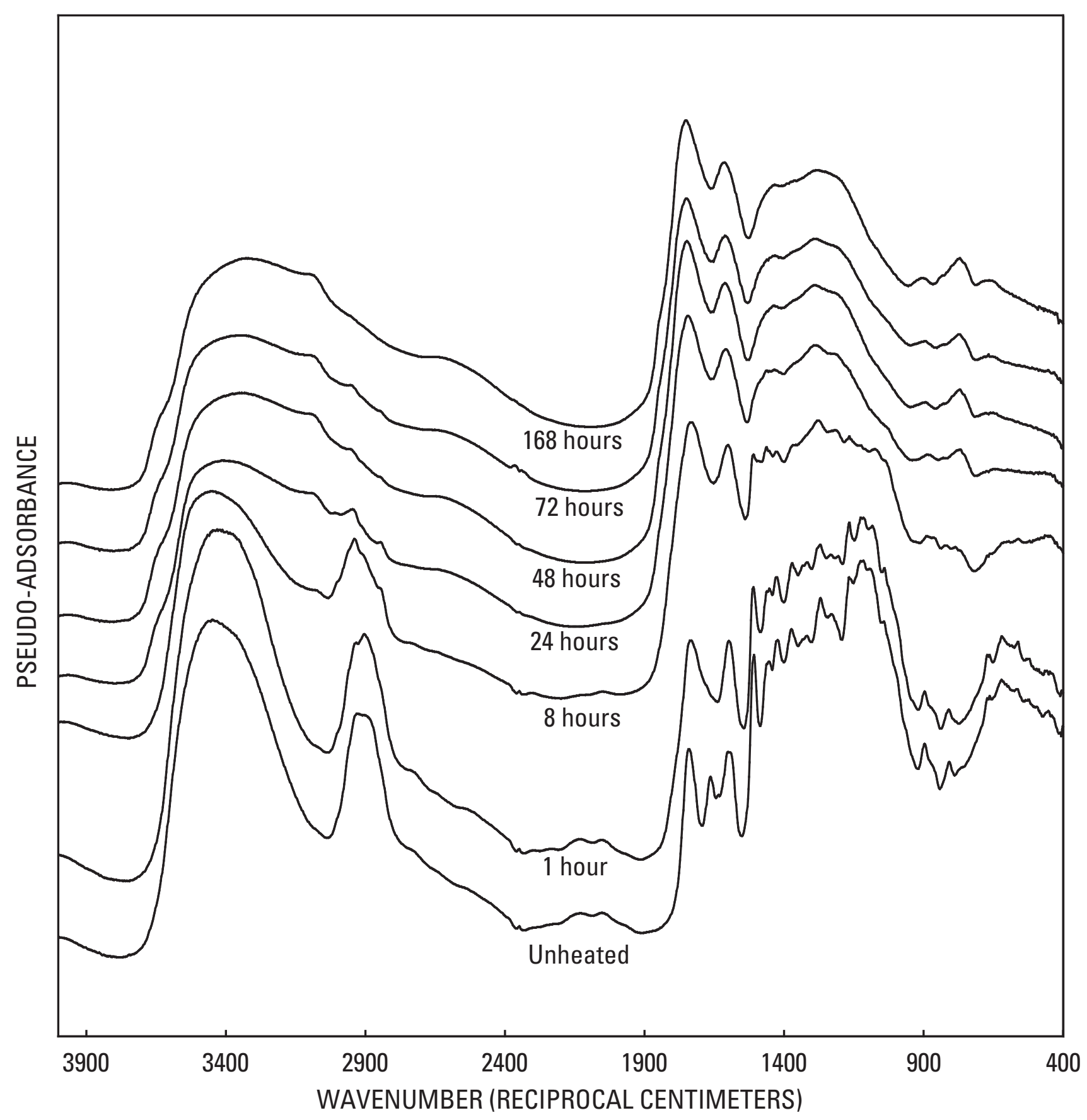

Figure 2-11. Diffuse reflectance mid-range infrared spectra of pine wood heated at $250^{\circ} \mathrm{C}$ for various times. 


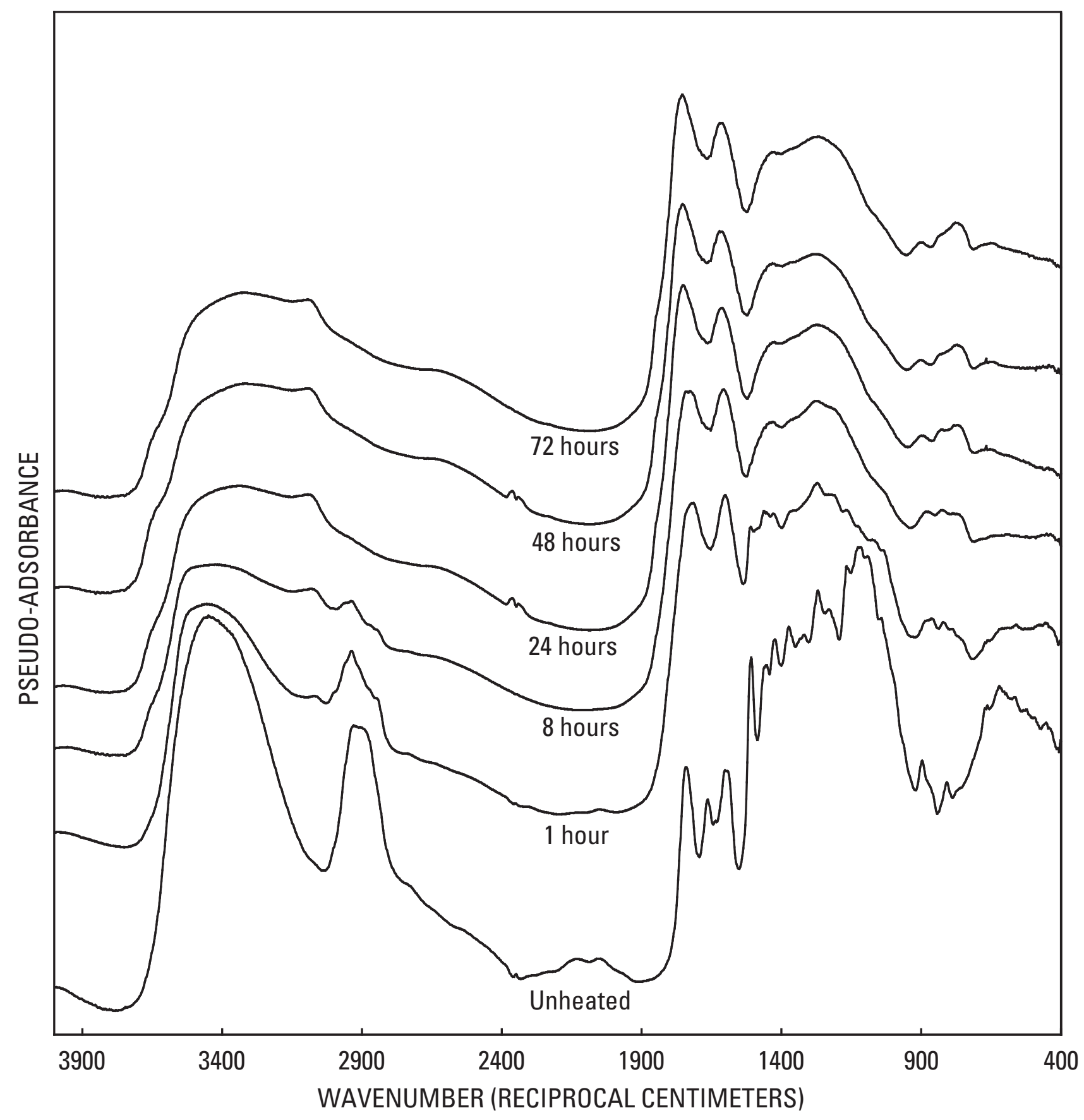

Figure 2-12. Diffuse reflectance mid-range infrared spectra of pine wood heated at $300^{\circ} \mathrm{C}$ for various times. 


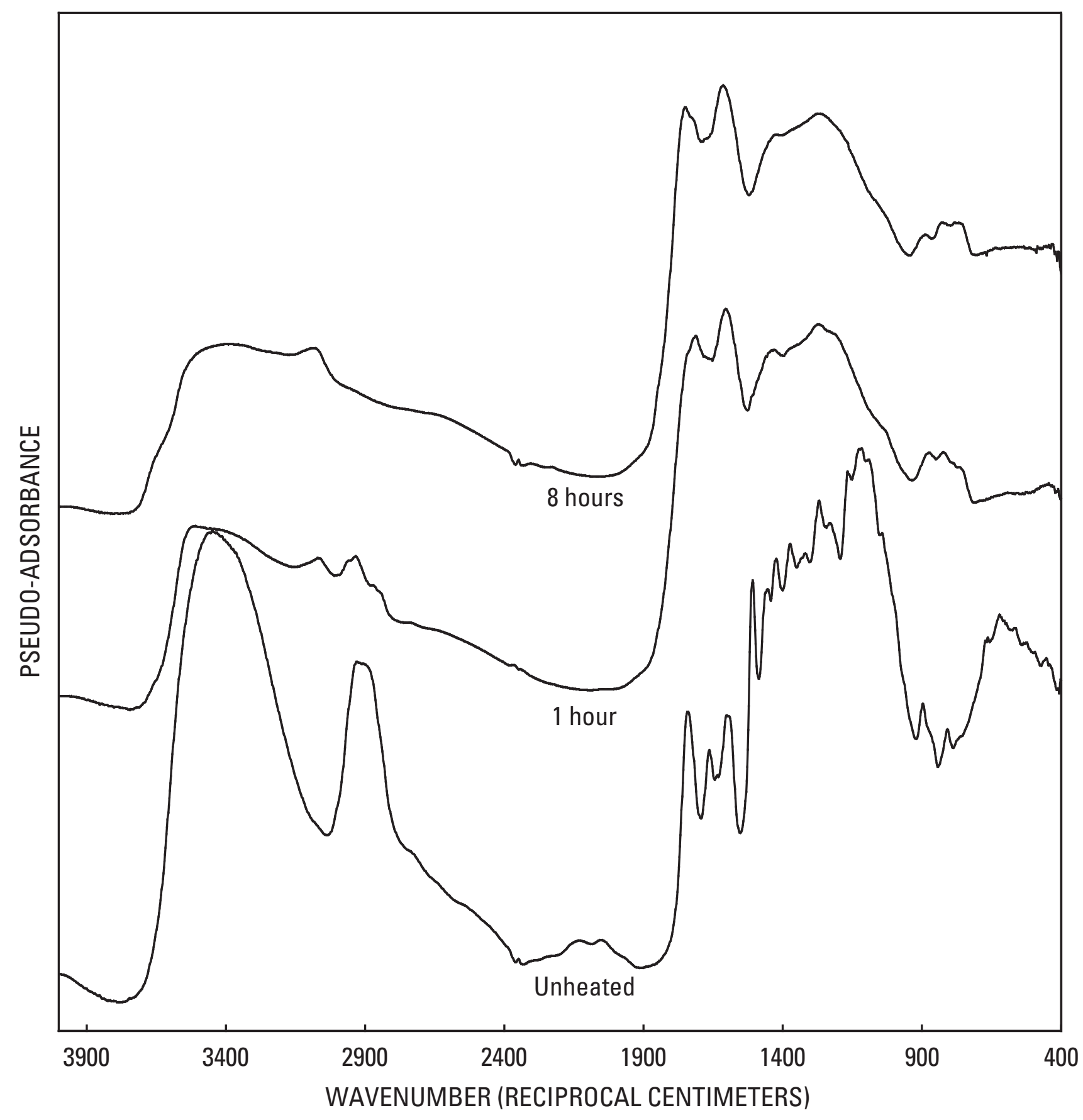

Figure 2-13. Diffuse reflectance mid-range infrared spectra of pine wood heated at $350^{\circ} \mathrm{C}$ for various times. 


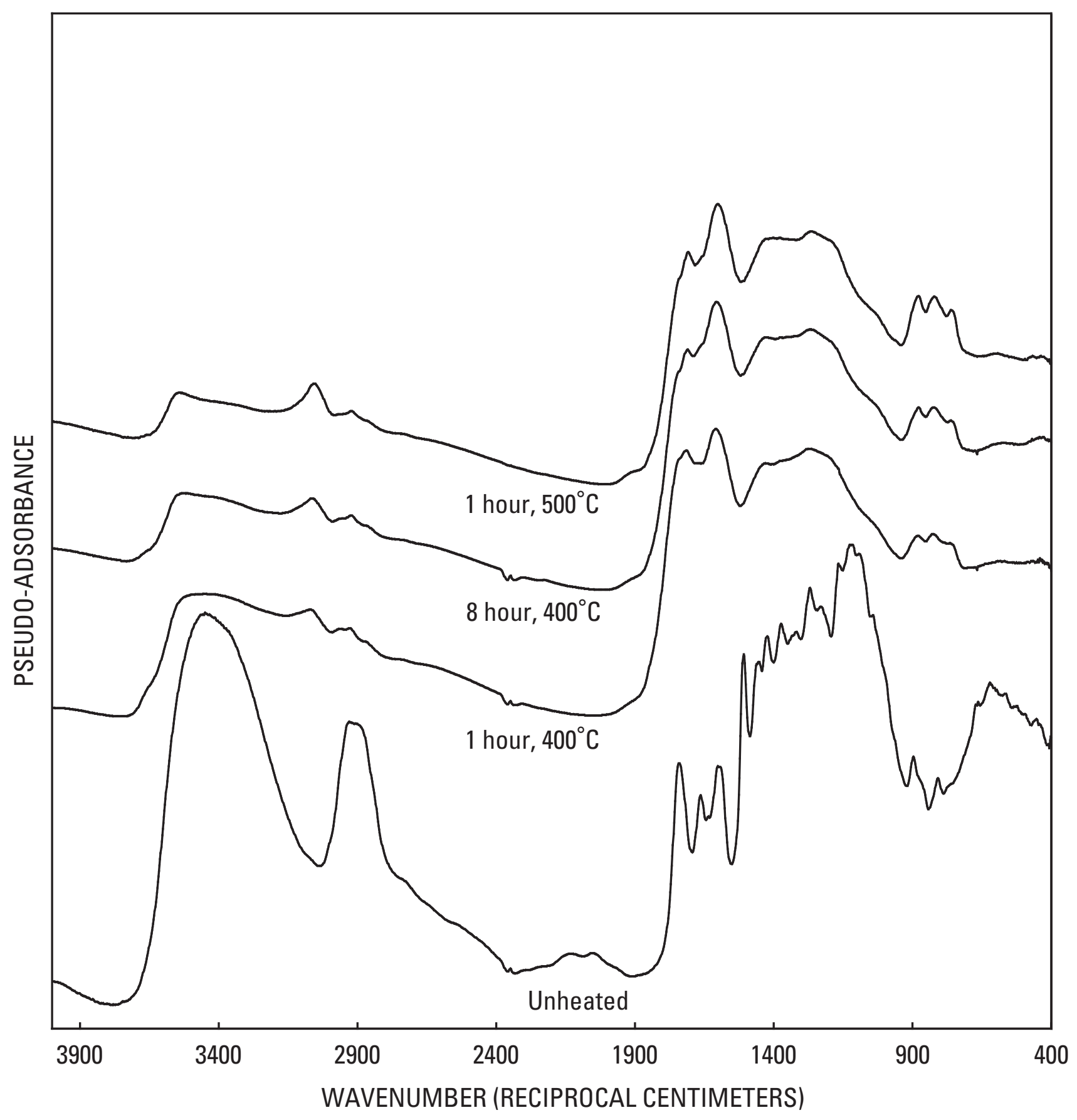

Figure 2-14. Diffuse reflectance mid-range infrared spectra of pine wood heated at $400^{\circ} \mathrm{C}$ and $500^{\circ} \mathrm{C}$ for various times. 


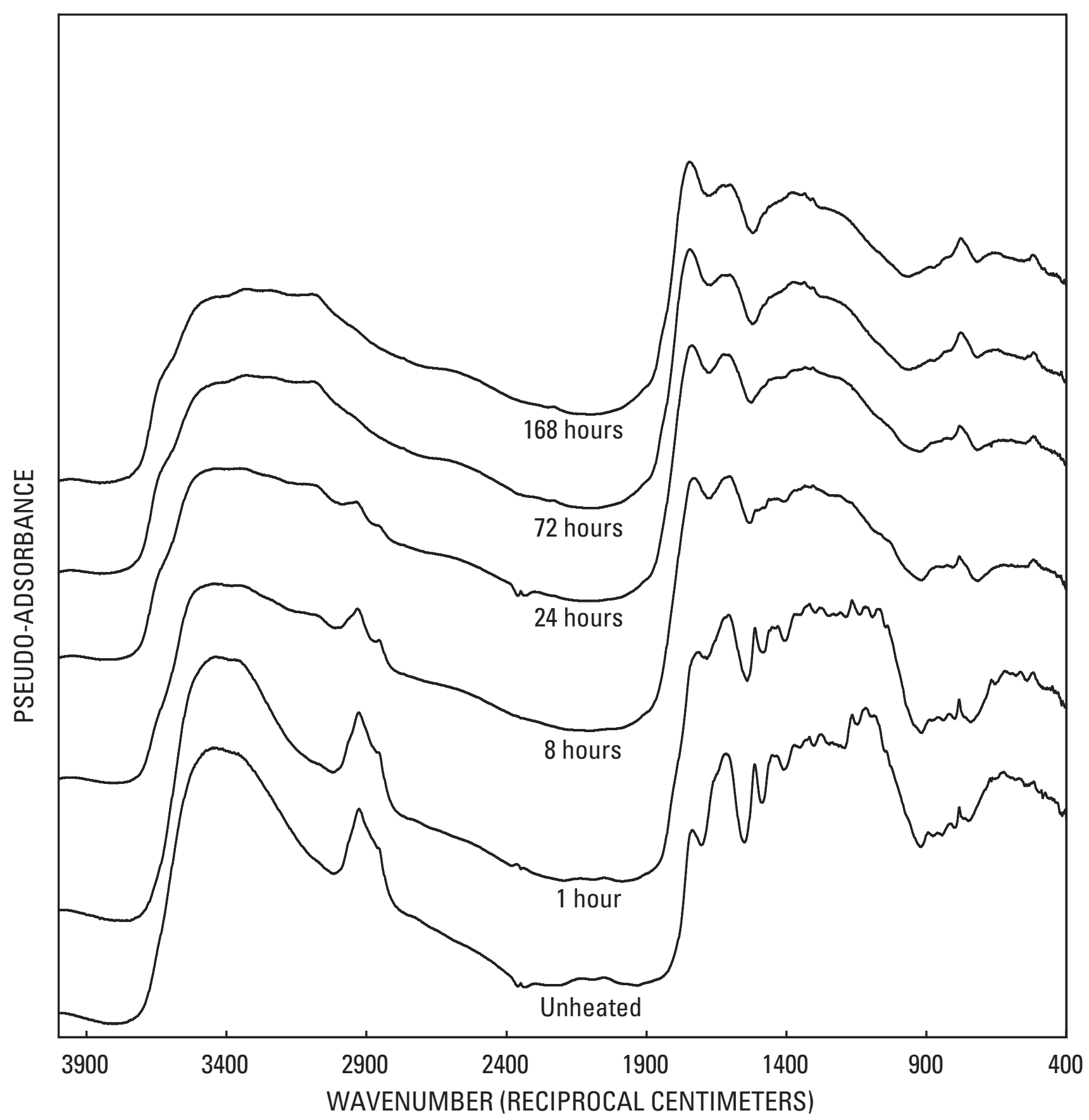

Figure 2-15. Diffuse reflectance mid-range infrared spectra of pine bark heated at $250^{\circ} \mathrm{C}$ for various times. 


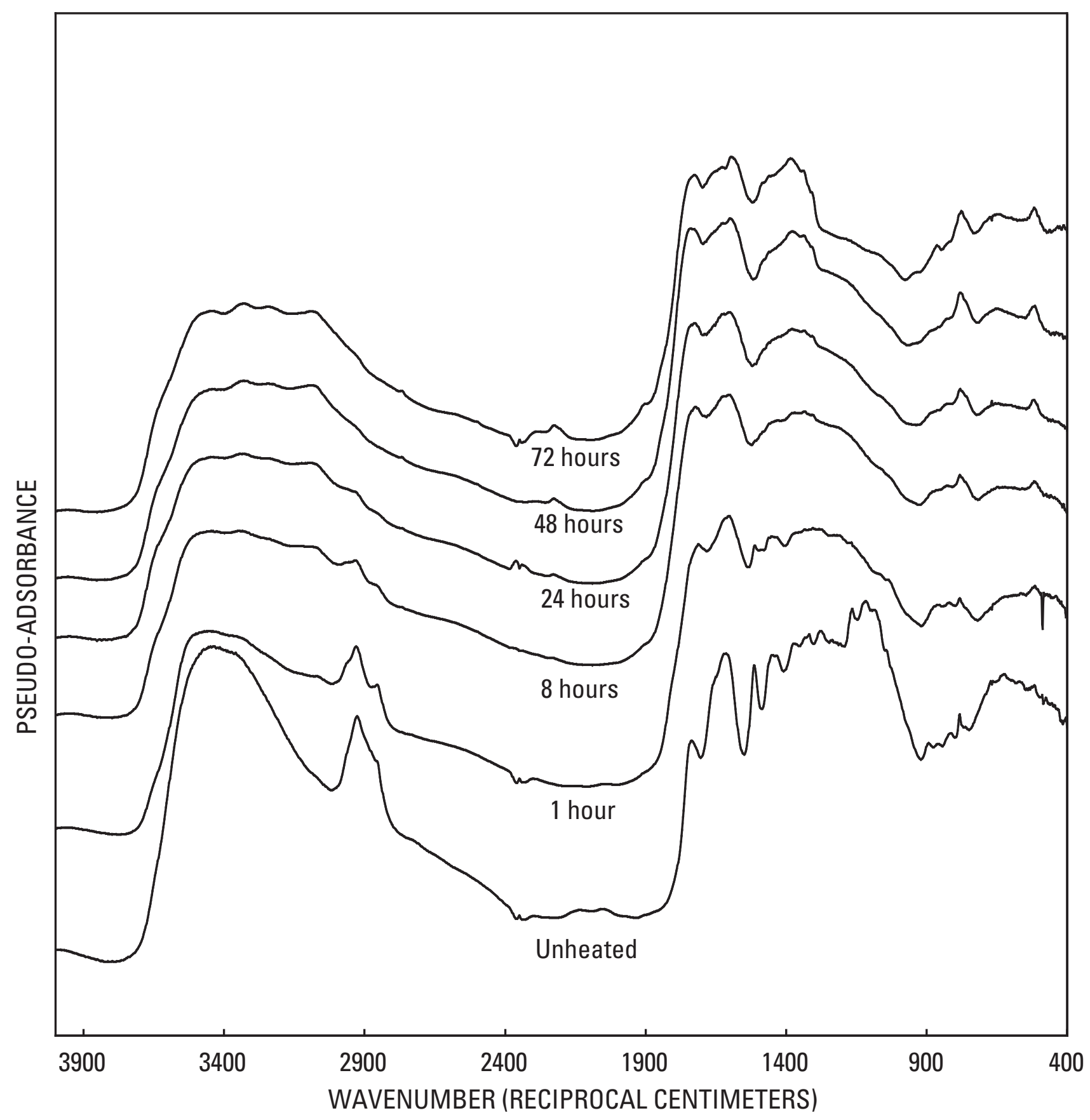

Figure 2-16. Diffuse reflectance mid-range infrared spectra of pine bark heated at $300^{\circ} \mathrm{C}$ for various times. 


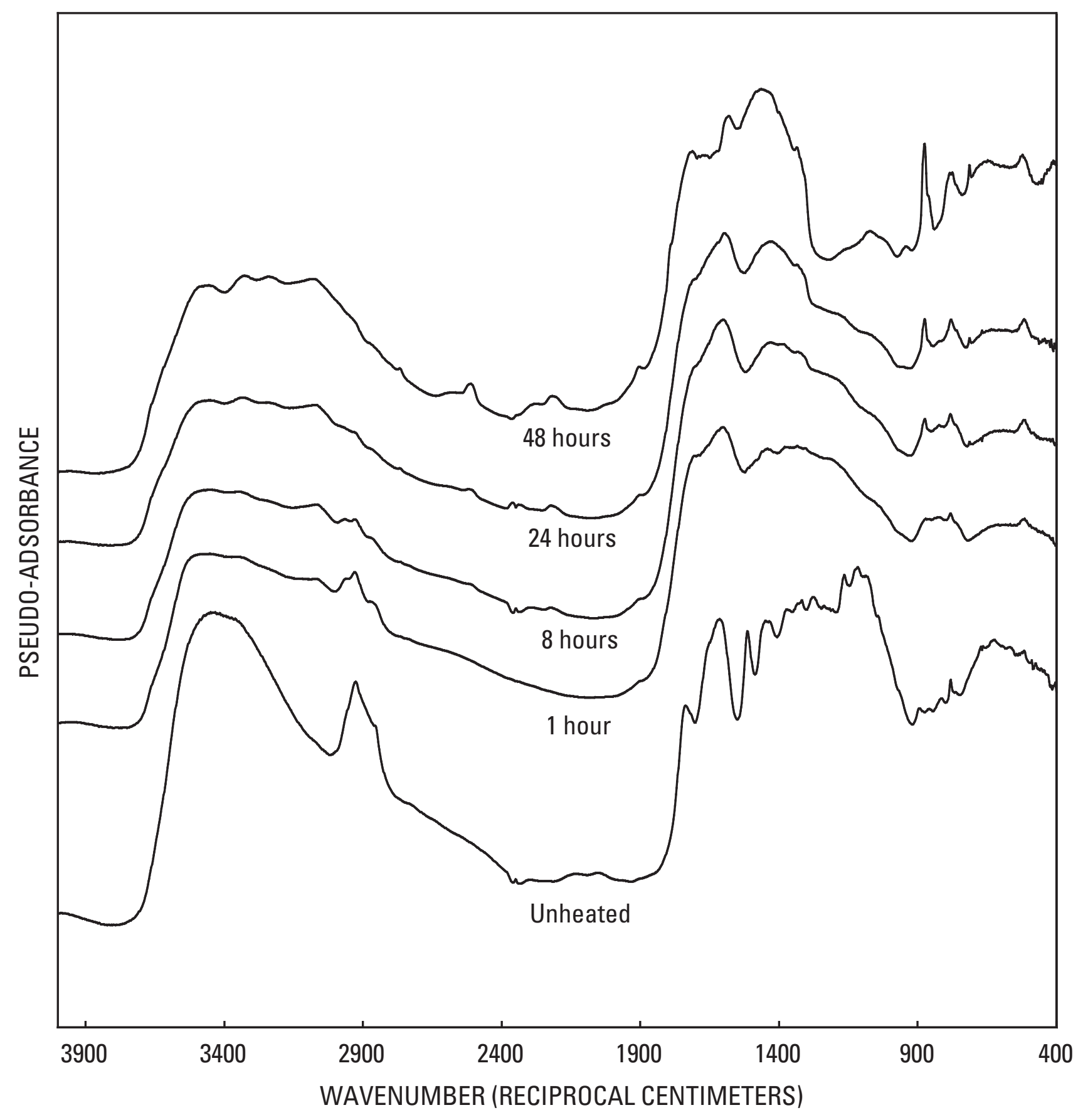

Figure 2-17. Diffuse reflectance mid-range infrared spectra of pine bark heated at $350^{\circ} \mathrm{C}$ for various times. 


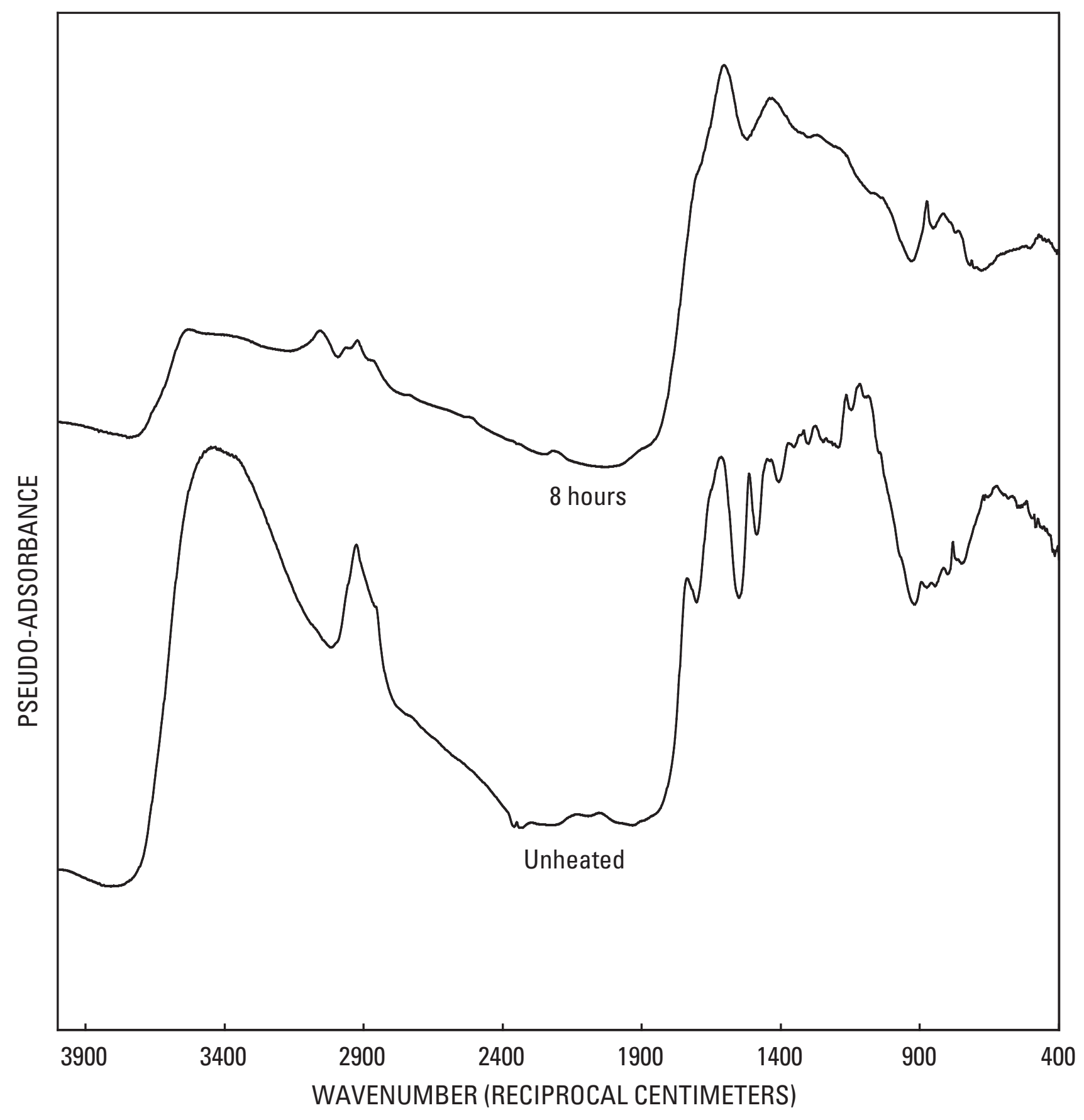

Figure 2-18. Diffuse reflectance mid-range infrared spectra of pine bark heated at $400^{\circ} \mathrm{C}$ for various times. 


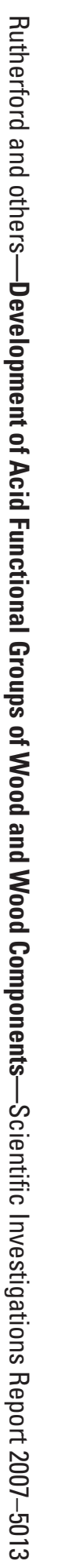

